\title{
Overview on agricultural potentials of biogas slurry (BGS): applications, challenges, and solutions
}

\author{
Ajay Kumar $^{1,2} \cdot$ Lahur Mani Verma $^{1} \cdot$ Satyawati Sharma ${ }^{1} \cdot$ Neetu Singh $^{2}(-)$ \\ Received: 31 August 2021 / Revised: 29 November 2021 / Accepted: 7 December 2021 \\ (c) The Author(s), under exclusive licence to Springer-Verlag GmbH Germany, part of Springer Nature 2022
}

\begin{abstract}
The residual slurry obtained from the anaerobic digestion (AD) of biogas feed substrates such as livestock dung is known as BGS. BGS is a rich source of nutrients and bioactive compounds having an important role in establishing diverse microbial communities, accelerating nutrient use efficiency, and promoting overall soil and plant health management. However, challenges such as lower $\mathrm{C} / \mathrm{N}$ transformation rates, ammonia volatilization, high $\mathrm{pH}$, and bulkiness limit their extensive applications.

Here we review the strategies of BGS valorization through microbial and organomineral amendments. Such cohesive approaches can serve dual purposes viz. green organic inputs for sustainable agriculture practices and value addition of biomass waste. The literature survey has been conducted to identify the knowledge gaps and critically analyze the latest technological interventions to upgrade the BGS for potential applications in agriculture fields.

The major points are as follows: (1) Bio/nanotechnology-inspired approaches could serve as a constructive platform for integrating BGS with other organic materials to exploit microbial diversity dynamics through multi-substrate interactions. (2) Advancements in next-generation sequencing (NGS) pave an ideal pathway to study the complex microflora and translate the potential information into bioprospecting of BGS to ameliorate existing bio-fertilizer formulations. (3) Nanoparticles (NPs) have the potential to establish a link between syntrophic bacteria and methanogens through direct interspecies electron transfer and thereby contribute towards improved efficiency of AD. (4) Developments in techniques of nutrient recovery from the BGS facilities' negative GHGs emissions and energy-efficient models for nitrogen removal. (5) Possibilities of formulating low-cost substrates for mass-multiplication of beneficial microbes, bioprospecting of such microbes to produce bioactive compounds of anti-phytopathogenic activities, and developing BGS-inspired biofertilizer formulations integrating NPs, microbial inoculants, and deoiled seed cakes have been examined.
\end{abstract}

Keywords Biogas slurry $\cdot$ Agriculturally important microbes $\cdot$ Deoiled seed cakes $\cdot$ Bio-fertilizer formulations $\cdot$ Bio/nano technology $\cdot$ Sustainable agriculture

$\begin{array}{ll}\text { Abbreviations } \\ \text { AAOB } & \text { Ammonia-oxidizing bacteria } \\ \text { ACD } & \text { Anaerobic co-digestion } \\ \text { ACE } & \text { Abundance-based coverage estimators } \\ \text { ACM } & \text { Acetoclastic methanogens } \\ \text { AD } & \text { Anaerobic digestion } \\ \text { ADDC } & \text { Agricultural digestate dry condition } \\ \text { ADG } & \text { Anaerobic digester } \\ \text { AIM } & \text { Agriculturally important microbes } \\ \text { ANOB } & \text { Anaerobic-oxidizing bacteria } \\ \text { AQS } & \text { Aqueous solubility } \\ \text { AR-W } & \text { Agricultural residue waste } \\ \text { ATP } & \text { Adenosine triphosphate } \\ \text { BCL } & \text { BGS cultivated lands } \\ \text { BD } & \text { Buffalo dung }\end{array}$




\begin{tabular}{|c|c|c|c|}
\hline BGS & Biogas slurry/bioslurry & NEDOCs & Non-edible deoiled cakes \\
\hline BGSY & Biogas yield & NGS & Next-generation sequencing \\
\hline BSM & Biostimulation & NOB & Nitrite-oxidizing bacteria \\
\hline $\mathrm{C} / \mathrm{N}$ & Carbon-to-nitrogen ratio & NPs & Nanoparticles \\
\hline CAGR & Compound annual growth rate & $\mathrm{nZVI}$ & Nanosized zero-valent iron \\
\hline \multirow[t]{2}{*}{ CANON } & Completely autotrophic nitrogen removal over & OTUs & Operational taxonomic units \\
\hline & nitrite process & PB & Plant biomass \\
\hline CBY & Cumulated biogas yields & PSB & Phosphate-solubilizing bacteria \\
\hline CCL & Chemically cultivated lands & QIIME & Quantitative insights into microbial ecology \\
\hline $\mathrm{CD}$ & Cow dung & SBAD & Substrate for anaerobic digestion \\
\hline CFs & Chemical fertilizers & $\mathrm{SC}$ & Slurry compost \\
\hline $\mathrm{CM}$ & Cattle manure & SI & Shannon index \\
\hline CMM & Cellular membrane & SNA & Syntrophic acetogens \\
\hline CNPs & Conductive nanoparticles & SOC & Soil organic carbon \\
\hline $\mathrm{CS}$ & Cattle slurry & SPB & Secondary fermenting bacteria \\
\hline DBS & Digested biogas slurry & TAN & Total ammonia nitrogen \\
\hline DIET & Direct interspecies electron transfer & TKN & Total Kjeldahl nitrogen \\
\hline DOCs & Deoiled cakes & TNC & Total nutrient content \\
\hline DOM & Dissolved organic matter & TS & Total solids \\
\hline DP & Dominant phylum & USD & United States dollar \\
\hline DPA & Dipicolinic acid & UTC & Coordinated universal time \\
\hline DVM & Digestate with vermiculite & V-GPM & Vacuum-assisted gas-permeable membrane \\
\hline EET & Extracellular electron transfer & VMD & Vacuum membrane distillation \\
\hline EU & European Union & VOA & Volatilization of ammonia \\
\hline FAO & Food and Agriculture Organization & VS & Volatile solids \\
\hline FYM & Farm yard manure & & \\
\hline GD & Goat dung & & \\
\hline GHGs & Greenhouse gases & \multicolumn{2}{|c|}{1 Introduction } \\
\hline HACs & High-ammonia conditions & & \\
\hline HED & Hen droppings & \multirow{2}{*}{\multicolumn{2}{|c|}{ 1.1 Background of the study }} \\
\hline HGM & Hydrogenotrophic methanogens & & \\
\hline $\mathrm{HM}$ & Horse manure & \multicolumn{2}{|c|}{ The prevalence of various types of abiotic and biotic stress } \\
\hline HOD & Horse dung & \multicolumn{2}{|c|}{ leads to a decline in crop productivity and consequently } \\
\hline HRT & Hydraulic retention time & \multicolumn{2}{|c|}{ accelerates the application of different types of chemical } \\
\hline IDR & Indonesian rupiah & \multicolumn{2}{|c|}{ fertilizers and pesticides in agriculture fields. Such chemical } \\
\hline IHT & Interspecies $\mathrm{H}_{2}$ transfer & \multicolumn{2}{|c|}{ inputs not only impose a threat to human life, but environ- } \\
\hline INR & Indian rupees & \multicolumn{2}{|c|}{ mental consequences are more pronounced. The application } \\
\hline $\mathrm{J}-\mathrm{DOC}$ & Jatropha deoiled cake & \multicolumn{2}{|c|}{ of nitrogenous chemical fertilizers has three important con- } \\
\hline K-DOC & Karanja deoiled cake & \multicolumn{2}{|c|}{ cerns, i.e., increasing cost (due to hikes in petroleum prices); } \\
\hline LCA & Life cycle assessment & \multicolumn{2}{|c|}{ economic loss (over $50 \%$ of applied nitrogenous fertilizers } \\
\hline LFD & Liquid fraction of the digestate & \multicolumn{2}{|c|}{ lost in different agriculture processing); and environmental } \\
\hline LR & Laser irradiation & \multicolumn{2}{|c|}{ hazards [1]. There is a gap of about 10 million ton (MTs) } \\
\hline LSS & Livestock slurry & \multicolumn{2}{|c|}{ of plant nutrients between removal by crops and replenish- } \\
\hline MBRs & Metal-binding receptors & \multicolumn{2}{|c|}{ ment through fertilizers, presently in India [1]. Such figures } \\
\hline MCNs & Micronutrients & \multicolumn{2}{|c|}{ necessitate transformation in our ideology from conventional } \\
\hline $\mathrm{Mg} \mathrm{ha}^{-1}$ & Mega gram per hectare & \multicolumn{2}{|c|}{ practices to environmental-friendly approaches, promoting } \\
\hline MIET & Mediated interspecies electron transfer & \multicolumn{2}{|c|}{ minimal or optimum use of chemical fertilizers or encourag- } \\
\hline MME & Microbial metabolic efficiency & \multicolumn{2}{|c|}{ ing organic farming. } \\
\hline MMTs & Million metric tons & \multicolumn{2}{|c|}{ Organic farming as a sustainable agriculture practice has } \\
\hline MNPs & Magnetite nanoparticles & gained glol & al attention in the present-day scenario; however, \\
\hline MT & Million ton & certain cha & llenges to widen the scope of such practices need \\
\hline NAR & Nijhuis ammonium recovery & to be addre & ssed. As per the data published in "The World of \\
\hline NBS & Nutrient subsidy rates & Organic A & rriculture (Statistics and emerging trends 2020)" \\
\hline
\end{tabular}


(FiBL survey 2020), there are 186 countries involved in organic activities in the year 2018 with 71.5 million hectares of land covered under organic agriculture. However, as far as the worldwide organic producers are concerned, India $(1,149,371)$ (2018 data) has maximum numbers followed by Uganda $(210,352)$ (2016 data) and Ethiopia $(203,602)$ (2015 data) (FiBL Survey 2020) [2]. The USA is the worldwide leader of the organic market followed by Germany and France with retail sales of 40559, 10919, and 9139 million euros respectively, while in terms of per capita consumption Denmark and Switzerland top the chart (FiBL-AMI survey 2020, 2018 data) [2]. Besides offering numerous benefits to the environment, issues like low productivity and higher produce cost are some of the key challenges that limit the interest of organic producers at large. A survey study by Ramesh et al. [3] also put forward similar concerns.

The amendments in biological resources (principally those considered as biomass waste or byproducts) to develop organomineral biofertilizers through the implementation of technological interventions such as microbiology, biotechnology, and nanotechnology are the key areas that must be looked upon to further strengthen organic agriculture practices. Biogas slurry/bioslurry (BGS) is one such residual biomass, which hosts a diverse microbial population, and accumulates secondary metabolites, carrying essential micro/macro-nutrients. Cow dung (CD), one of the common biogas feedstock and BGS source, is rich in mineral elements like $\mathrm{N}, \mathrm{P}, \mathrm{Ca}, \mathrm{Zn}, \mathrm{Mg}, \mathrm{S}, \mathrm{Fe}, \mathrm{Cu}, \mathrm{Co}$, and $\mathrm{Mn}[4]$ and harbors diverse microbial population [5]. The full potential of $\mathrm{CD}$ in areas such as agriculture, energy, environment, and human health is still unexplored [5]. BGS demonstrates potential applications as a soil conditioner, fertilizer, and bio-pesticide in agriculture. The detailed discussion over different applications of BGS in crop fields is presented in Section 2.2. Taking account of shortcomings, it has been observed that BGS alone is unable to fulfill the entire nutrient demand due to its bulkiness, $\mathrm{N}$ loss as ammonia volatilization, reduced rates of $\mathrm{C} / \mathrm{N}$ transformation, etc. [6-8]. The major limitations and emerging challenges for BGS applications in the agriculture fields have been outlined in the next section.

\subsection{Limitations of BGS: need for value addition}

BGS obtained from animal dung such as cattle and livestock have nutrient profile contributed as a potential source of fertigation in agriculture fields. However, BGS has various limitations such as bulkiness, low $\mathrm{C} / \mathrm{N}$ ratio, nitrogen loss through volatilization of ammonia (VOA), and high pH (Fig. 1). A biogas plant with $800 \mathrm{~m}^{3}$ of working volume is estimated to be discharged 15 tons of BGS per day [9]; hence, generated volumes of BGS need to be managed appropriately to avoid any environmental consequences, as a result thereof. The bulkiness in BGS is due to the high water content ( 93\%) in it [10-12], which further complicates its transport and utilization [13]. The bulkiness of BGS also limits its potential to fulfill the entire nutrient demand [7] in agriculture fields.

Loss of nitrogen as VOA from liquid slurry depends upon different physical (liquid temperature, viscosity, contents, and distribution of particle size in solids), chemical ( $\mathrm{pH}$, ionic strength, and total ammonical nitrogen), and environmental (temperature, humidity, direction, and speed of the
Fig. 1 Limitations of BGS as a potential nutrient input in agriculture fields (contamination include pathogens, heavy metals, organic pollutants, pesticides, antibiotics, etc.) (conceptualized from [6-8, 21])

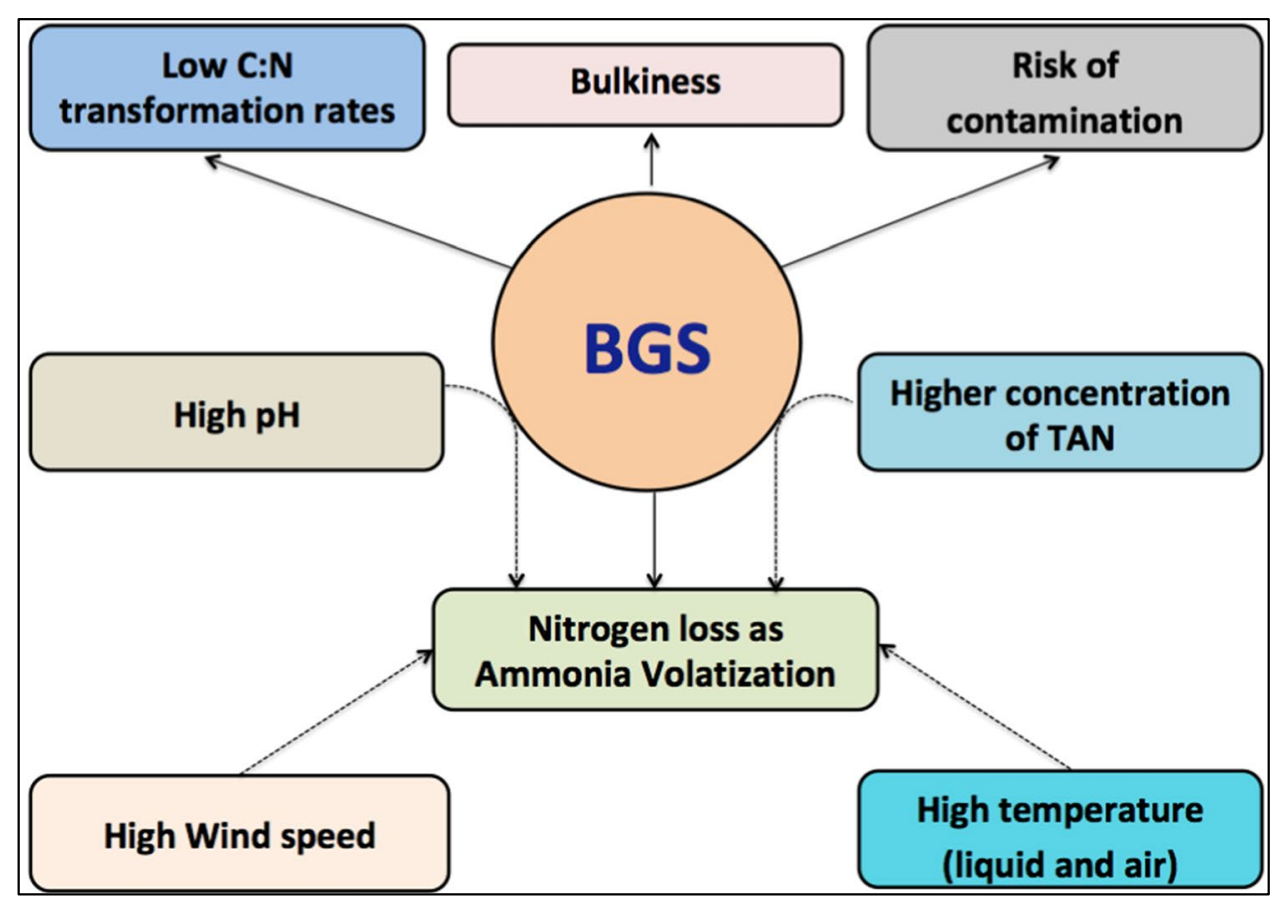


wind, etc.) factors [8]. Such losses were also observed at the time of drying BGS or soon after its application in agriculture fields [14]. BGS have $\mathrm{pH}$ values usually in the alkaline range $[11,14,15]$, and as per the reports, the higher $\mathrm{pH}(>7)$ promotes $\mathrm{N}$ loss through VOA [16].

Nitrogen loss from BGS in the form of VOA imposes complexity during its handling, storage, and field applications [14]. Storage limitations such as lack of bottom liners or impermeable surfaces can have the risk of nitrogen and potassium leaching [14]. Under circumstances where the proper covering of recovered BGS is not available, the risk of ammonia emissions can further increase [14]. For convenient handling, BGS often dried or composted, which can also end up with $\mathrm{N}$ losses as VOA [14]. However, such losses can be minimized with the use of nitrogen-rich organic substrates during composting of BGS. High air temperature can also increase the $\mathrm{N}$ loss through ammonia emissions [16]. Studies mentioned that the available nitrogen in BGS is comparatively less efficient than mineral fertilizers due to such $\mathrm{N}$ losses [17]. The ammonia deposition as a consequence of increasing VOA is reportedly associated with the risk of acidification in sensitive ecosystems [18], besides this, ammonia also act as precursor for secondary aerosols production [19].

Zheng et al. [6] reported low $\mathrm{C} / \mathrm{N}$ transformation rates in biogas digestate obtained from farm manure (pig manure and urine). The low carbon and high nitrogen contents in anaerobic digestates [14] are primarily attributed to the conversion of carbon-rich substrate into methane. Studies reported mixed responses (i.e., positive, negative as well as no effects) of $\mathrm{N}$ availability on mineralization of soil organic carbon (SOC) [20]. As cited by Insam et al. [21] and Stumpe et al. [22] and mentioned in the study of Senbayram et al. [23], the elevated levels of nitrogen in digestates can increase the mineralization of carbon (called as priming effect). High and low priming effects were reportedly observed under lower (higher $\mathrm{C} / \mathrm{N}$ ratio) and higher $\mathrm{N}$ availability (low $\mathrm{C} / \mathrm{N}$ ratio) respectively [24]. Liu et al. [24] reported higher SOC stocks and lower respiration activity of soil microbes under nitrogen deposition conditions. Researchers also speculate the role of soil microbial community in the degradation of BGS-derived recalcitrant organic carbon present in topsoil, hence, mounting the SOC stocks [25]. Liao et al. [20] mentioned that the decrease in priming effect under the conditions of higher nitrogen availability is majorly controlled by "microbial metabolic efficiency" (MME). Similar findings were reported earlier, and Chen et al. [26] also concluded that instead of microbial activity (extracellular enzymatic activities), the dynamics of carbon in topsoil under higher nitrogen availability is regulated by MME. As mentioned by Groot and Bogdanski [19], in spite of the higher mineralization of nitrogen at a low $\mathrm{C} / \mathrm{N}$ ratio, the susceptibility towards emissions of ammonia increases.
To further explore this, we have reviewed the study of Senbayram et al. [23]. The application of organic matter in combination with ammonium sulfate initially increases the readily available SOC. Following the rapid decomposition of easily degradable carbon compounds, the ratio of nitrate nitrogen and available carbon increases, and once reached threshold levels, it may induce $\mathrm{N}_{2} \mathrm{O}$ emissions under the conditions of high soil moisture [23].

The direct application of liquid BGS in agriculture fields (such as foliar spray) is also an important consideration. To avoid the toxicity risk on plant growth as a result of higher concentration of ammonia and soluble $\mathrm{P}$, it has been recommended to dilute the liquid BGS before applying on standing crops based on the type of biodigester (like floating drum/ fixed dome type; tubular/plug-flow type, etc.) [17]. The application of recovered digestates can also induce phytotoxicity effects precisely when used as a peat substitute in nursery/horticulture plantations, which more likely depends on the content of soluble salts in digestates [14].

The BGS concentration is another important aspect and as reported by Warnars and Oppenoorth [17]; it depends upon the absorption rate of plants at the time of slurry application. Niyungeko et al. [15] observed an increase in colloidal phosphorous leaching from paddy (rice) topsoil at medium $\left(673 \mathrm{~m}^{3} \mathrm{ha}^{-1}: 165 \mathrm{~kg} \mathrm{~N} \mathrm{ha}^{-1}, 52 \mathrm{~kg} \mathrm{P} \mathrm{ha}^{-1}\right)$ and high (1350 $\mathrm{m}^{3} \mathrm{ha}^{-1}: 330 \mathrm{~kg} \mathrm{~N} \mathrm{ha}^{-1}, 104 \mathrm{~kg} \mathrm{P} \mathrm{ha}^{-1}$ ) application rate of BGS. Warnars and Oppenoorth [17] recommended lower application doses of BGS to limit the $\mathrm{N}$ loss as nitrate leaching. Over-fertilization with BGS can risk the environment (VOA causes atmospheric pollution) and also incurred with financial losses (loss of fertilizer nitrogen) [19].

Reports indicated that the possibilities of pathogens and heavy metal contaminants in BGS are lesser in the case of using manure over other waste streams as feedstock material for AD [14]. However, it is noteworthy that the degradation of heavy metals does not occur during AD [27]. Hence, it is important to study the fate of heavy metal transfer on receiving environment as a consequence of BGS fertilization, more precisely the long-term application effects. Bian et al. [28] treated farmland soil with BGS (pig manure and straw as feedstock material for $\mathrm{AD}$ ) and investigated the concentrations of heavy metals in different soil and plant samples. They observed higher levels of $\mathrm{Cd}, \mathrm{Pb}$, and $\mathrm{Zn}$ (mean concentrations) in soil amended with BGS (which exceeds standard safety limits as referred to in the study), and the plants were found to have heavy metals (under investigation) above the standard safety limits as referred to in the study (except $\mathrm{Cu}$ ). Overall, leafy vegetables showed higher heavy metal uptake as compared to the non-leafy vegetables. Risk assessment through plant ingestion displayed higher "noncarcinogenic risk" with heavy metals $\mathrm{As}, \mathrm{Cd}$, and $\mathrm{Pb}$; while the carcinogenic risk (CGR) was found to be associated with $\mathrm{Cr}>\mathrm{As}>\mathrm{Cd}$ (decreasing order), out of them, CGR through 
food chain was primarily ascribed to $\mathrm{Cd}$ and As [28]. Tang et al. [27] found concentrations of heavy metals $(\mathrm{Cd}, \mathrm{Cu}$, $\mathrm{Pb}$, and $\mathrm{Zn}$ ) in soil and crop plants (Rice and Wheat) after 5 years following repeated fertilization with BGS (pig manure as feedstock material for AD) within the standard safety limits as laid down by different international bodies (China, EU, and FAO). In another interesting study by $\mathrm{Lu}$ et al. [29], the effect of BGS (called anaerobically digested slurry by the authors) (pig farm waste as feedstock material for $\mathrm{AD}$ ) fertigation on rice grain yield and accumulation of heavy metals in harvested rice grains was investigated. They have recorded the heavy metal concentration in BGS as $\mathrm{Cu}>\mathrm{Cd}>\mathrm{Pb}>\mathrm{Cr}>\mathrm{Hg}$ (decreasing order), and observed levels of heavy metals in soil (before transplantation of rice and after harvesting) as well as in rice grains were found lower than the standard critical levels as referred to in the study, and the heavy metal concentration in harvested grains were independent of the dose of BGS application in fields.

In addition to this, it is also important that the BGS must be well-treated to be free from contaminations such as pathogens [17]. That could be of concern in scenarios where stringent measures (such as optimum retention time, $\mathrm{pH}$, digester temperature [21]) during $\mathrm{AD}$ of feedstock materials will not be followed. Studies mentioned that managing such consistencies in operational conditions might be more challenging for developing countries [14]. Though the occurrence of pathogens in BGS is comparatively lesser than FYM, however, the risk cannot be ignored completely as the process of $\mathrm{AD}$ does not kill the entire range of pathogens [17]. In addition to pathogens and heavy metals, the presence of antibiotics and different organic pollutants (including pesticides) is some of the emerging challenges while using the BGS for agriculture applications [21]. Pointing to the existing challenges with the application of BGS as a rationale behind the present study and prioritizing the concept of sustainable agriculture practices, we have attempted to highlight the latest technological developments fostering the value addition of BGS.

\section{BGS: source, composition, and agricultural applications}

\subsection{Source and composition}

Biogas is comprised of methane (major component), carbon dioxide, nitrogen, hydrogen sulfide, hydrogen, and traces of ammonia [30]. Hydrolysis, acidogenesis, acetogenesis, and methanogenesis are the key steps of biogas production in which each step is catalyzed by the diverse microflora [31]. Different substrates for AD to produce biogas include animal (manure, dung, fodder residue, etc.), vegetable (grass, straw, etc.), and household (night soil, garbage, etc.) waste
[32]. Livestock dung (such as cattle manure) is the most commonly available substrate for biogas production [33], precisely in rural areas.

Discussing the Indian scenario, from 730 MT of dung produced by animals annually, bovine dung alone (cattle and buffalo dung) accounts for 256.2 MT from which estimated annual BGS production is $76.8 \mathrm{MT}$ (at $1 \mathrm{~kg}$ cattle dung= $\sim 0.3 \mathrm{~kg}$ BGS) [10]. In another study by Thiruselvi et al. [34], the amount of CD generated in India has been reported around 335 MT per month (out of which 110 MT is considered to be waste during collection and transportation). Referring to Kumar et al. [10], we can estimate the monthly BGS recovery rates after AD of $\sim 225 \mathrm{MT}$ CD. Rath and Joshi [35] mentioned the estimated annual bioslurry recovery of 299 MT from 995 MT of bovine dung. Such values direct the extent of digestate availability from the biogas plants. As per the case study conducted in Rajasthan (India) [36], the majority of biogas plant owners preferred to use recovered BGS as fertilizer. Considering this awareness among the farmers, the application of integrated approaches leading to the value addition of BGS to develop low-cost Bio-Agri inputs will be of great significance to further promote its full potential with anticipations of reducing our dependence on chemical fertilizers.

Biogas slurry or bioslurry abbreviated as BGS in the present study recovered as the spent from the AD of organic feeds during biogas production. The bulk of BGS is contributed by water ( 93\%) and the remaining part ( 7\%) is comprised of organic $(4.5 \%)$ and inorganic $(2.5 \%)$ matter [10-12]. $\mathrm{pH}$ value lies above the neutral range [37]. It is rich in NPK with other nutrients $(\mathrm{Ca}, \mathrm{Mg}, \mathrm{Fe}, \mathrm{Mn}, \mathrm{Cu}$, and $\mathrm{Zn}$ ) essential for plant growth [38]. One of the latest studies mentioned $2.55 \%, 0.57 \%$, and $1.77 \%$ of $\mathrm{N}, \mathrm{P}$, and $\mathrm{K}$ respectively in BGS [33]. Sharma et al. [39] in sun-dried BGS reported $\mathrm{C}, \mathrm{N}, \mathrm{P}$, and $\mathrm{K}$ content of $41.6 \pm 2.1 \%, 0.72 \pm 0.12 \%$, $0.59 \pm 0.02 \%$, and $0.91 \pm 0.04 \%$ respectively.

Mdlambuzi et al. [33] observed a direct relationship between the NPK content of cattle manure (CM) and recovered BGS, i.e., higher N, K, and lower P content. It is worth mentioning here that the nutritional status of recovered BGS relies upon several aspects such as the source of feedstock substrate, operational conditions in AD, and native microflora. Hence, it is important to optimize the substrate combination coupled with operational conditions during $\mathrm{AD}$, which can yield twin benefits of higher biogas yields and nutrient-enriched BGS. Organic matter has a low $\mathrm{C} / \mathrm{N}$ ratio, which limits the process of $\mathrm{AD}$ [40]. As the animal manures have low $\mathrm{C} / \mathrm{N}$ content, it is ideal to perform co-digestion with the substrates having high carbon to low nitrogen content such as plant biomass. Co-digestion studies using plant biomass with livestock wastes such as CD [41, 42] and poultry litter [43] are well documented. This will facilitate $\mathrm{C} / \mathrm{N}$ balance, favoring microbial breakdown of substrate mixture 
in the digester [44]. Rodríguez-Abalde et al. [45] reported higher methane yields at a $\mathrm{C} / \mathrm{N}$ ratio of 20-30. Wei et al. [46] optimized the combination of $\mathrm{CM}$, maize straw, and sewage sludge (35:35:30) for higher methane yields. Priya et al. [47] performed co-digestion of plant biomass with organic wastes and found higher levels of volatile solids (VS) leading to improved levels of biogas yield.

Interestingly, the anaerobic digestate obtained from digestion (of feed substrate, i.e., CM, pig slurry, and poultry litter) or co-digestion (with onion waste) shows similarity in their structural characteristics, and the recovered co-digestate showed improvement in the availability of nutrients [48]. Concluding this, the $\mathrm{C} / \mathrm{N}$ content is an important consideration while selecting substrates and optimizing their different combinations. The strategy of co-digestion with other feedstocks has also been reported to recuperate the process of $\mathrm{AD}$ [40]. We suggest further readings on the co-digestion of livestock manure with different feedstocks [31, 45, 49-51].

\subsection{Agricultural applications}

\subsubsection{Is BGS a preferred source of fertilizer over raw manure or traditional composts?}

Anaerobic digestates such as BGS comparatively offer low nitrate leaching and lesser nitrous oxide emissions [18]. Digestates from organic matter such as animal slurry reportedly contains more mineral nitrogen as compared to the undigested ones [52]. According to Aminul Haque [12], anaerobically decomposed BGS has a higher nutrient value than aerobically decomposed BGS. Smith et al. [53] observed higher nitrogen losses in composting (26-51\%) over AD (5-10\%). In comparison to traditional compost, BGS is an easily available form of compost [17] and is also reported to have stronger plant growth-promoting activities than raw slurries due to higher concentrations of ammonical nitrogen [54]. As compared to CD, BGS have lower $\mathrm{C} / \mathrm{N}$ content, thus enabling higher fertilization potential, and anaerobic digestion aids mineralization effects, hence increasing the bioavailability of nutrients to the plants [16], though the susceptibility towards N loss due to VOA can be increased [19]. Tumuhimbise [55] recorded higher biofertilizer potential of CM bioslurry as compared to the sundried slurry, fresh CM, and NPK treatments on the overall growth of radish in ferralsol soil. On reviewing the literature, BGS appears as a preferred source of nutrients (like N) with significant fertilizer potential [17, 53-56]. Research and development in the area of BGS enrichment to meet the current nutrient demands in agriculture fields coupled with searching opportunities to develop effective bioformulations against a wide range of pests will be of great significance to meet the objectives of organic farming and sustainable development goals.

\subsubsection{Nutrient profile of BGS}

As compared to CM, Mdlambuzi et al. [33] found 0.65\%, $0.133 \%$, and $0.10 \%$ higher values of $\mathrm{N}, \mathrm{P}$, and $\mathrm{K}$ content $(\%$ wt) in BGS respectively. According to Devarenjan et al. [11], $2 \mathrm{~m}^{3}$ of the biogas plant can produce around $50 \mathrm{~kg}$ of BGS every day and $1 \mathrm{~m}^{3}$ of BGS contains about 0.16 to $1.05 \mathrm{~kg}$ of nitrogen which is equal to approximately 0.35 to $2.5 \mathrm{~kg}$ of urea. Animal urine added to BGS increases nitrogen levels that accelerate the compost-making process and optimize the $\mathrm{C} / \mathrm{N}$ ratio in BGS that aids nutrient availability to soil biota and plants [10]. Jared et al. [38] recorded higher levels of $\mathrm{Ca}, \mathrm{Mg}, \mathrm{Fe}, \mathrm{Mn}$, and $\mathrm{Zn}$ in slurry compost as compared to BGS. However, from Fig. 2, it can be noticed that in terms of NPK values, BGS is preferred over slurry compost and farm yard manure (FYM). Incorporation of nutrient-rich organic amendments such as non-edible DOCs (NEDOCs) as a strategy to facilitate multi-substrate interaction of beneficial microbes and thereby to ameliorate micronutrient status of BGS has been proposed through the present review and will be discussed further upon.

\subsubsection{BGS as an organic fertilizer}

BGS offers various advantages as an organic fertilizer like improvement in soil nutrient profile and their availability to plants; improves soil structure, its water holding capacity, and cation exchange capacity; improves soil microbiota (nitrogen-fixing bacteria, phosphate-solubilizing bacteria (PSBs)); etc. [10]. Such organic amendments can further prevent or reduce soil erosion through improvements in the physical properties of soil (such as water-holding capacity [10], air permeability [6], aggregate stability, penetration resistance [57], etc.) along with an increase in soil organic carbon content [57]. BGS is a rich source of slow-release minerals [58] and provides nutrients in balanced proportions [59]. It can be utilized directly or indirectly as a fertilizer with other organic materials [10]. BGS can be applied as a foliar spray (onto crops), diluted liquid (onto roots), and dry composted form (combined with irrigation techniques to ensure sufficient water to crop plants) [37]. Zhao et al. [60] reported the preferential application of BGS in agriculture application as compost instead of its direct application. Referring to Table 1 , it has been observed that the BGS have a potential role in plant growth-promoting activities such as overall yield and productivity, improving nutrient contents in soil, and maintaining soil structure, effectivity against soil-borne, and plant pathogens, etc. Beneficial effects of BGS fertilization leading to the overall soil and plant health management are represented schematically in Fig. 3.

Plant growth and productivity Ferralsol soil fertilized with CM bioslurry promotes plant height and total biomass 


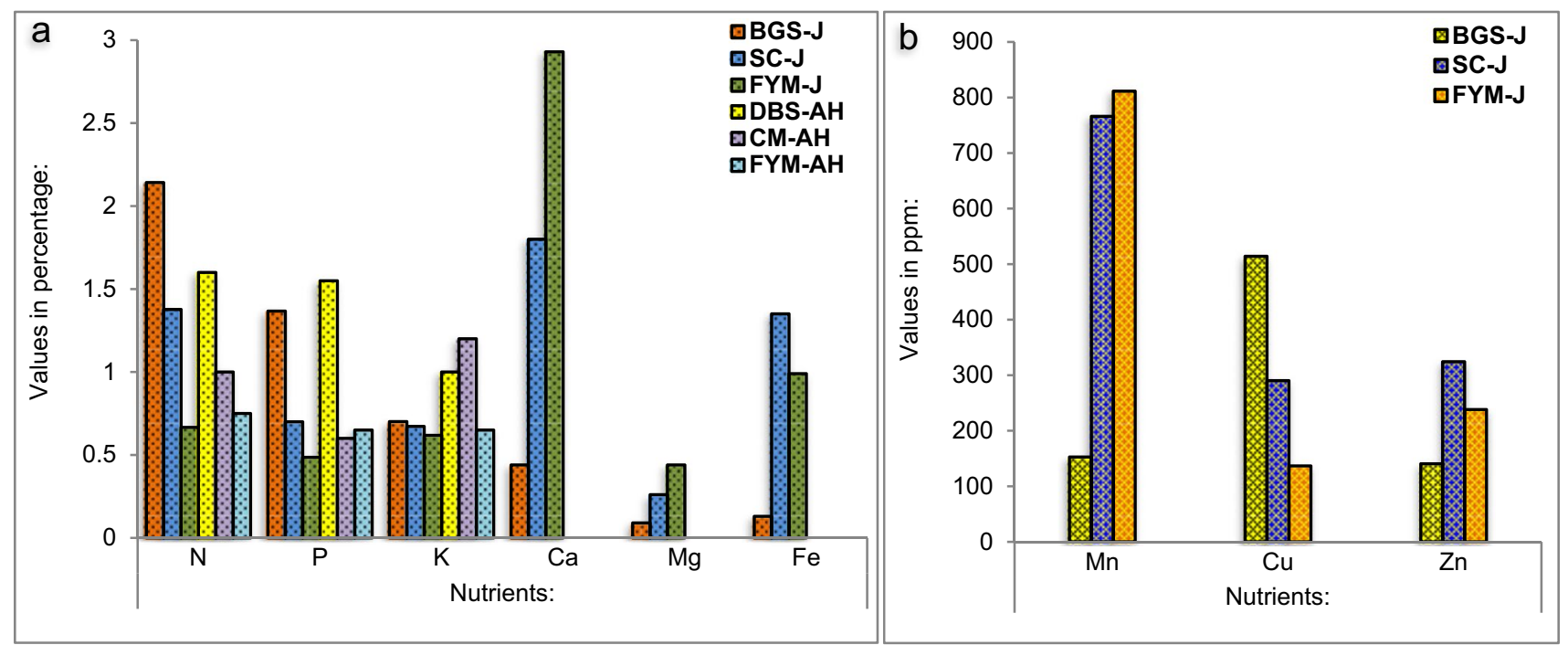

Fig. 2 Comparative analysis of nutrient composition in different organic inputs. a Macronutrients along with $\mathrm{Fe}$; b micronutrients $\mathrm{Mn}$, $\mathrm{Cu}$, and $\mathrm{Zn}$ (note: DBS-AH, CM-AH, and FYM-AH represent average data from three different regions/sample matrices; BGS-J, SS-J, and FYM-J represent average data derived from the range of values

content, and improves growth parameters such as root diameter, and leave number and weight, in radish [55]. Xu et al. [61] recorded the highest yields in rice and rape at an application rate of 165.1 and $182.1 \mathrm{tha}^{-1}$ BGS respectively. They [61] have observed comparatively better results than those obtained from chemical fertilizers treatment. Besides this, You et al. [58] fertilized red clay soil with BGS (at 30 and $40 \mathrm{~kg} / \mathrm{plant} / \mathrm{year}$ ) and noticed an improvement in fresh fruits yield, oil yield, and seed rate (fresh and dry) per plant in Camellia oleifera. Ferdous et al. [62] supplemented CD BGS with synthetic fertilizer (NPK, S, Zn, B) at an application rate of $5 \mathrm{tha}^{-1}$ and reported increasing tomato yields. Results of Xu et al. [37] showed an increase in overall growth, stomatal conductance, concentration of intercellular $\mathrm{CO}_{2}$, water-use efficiency, rate of transpiration, photosynthesis, etc., in Perilla frutescens seedlings. Aminul Haque [12] reported a higher manure value of BGS in Rabi crops than Kharif crops and mentioned that nitrogen content was higher in air-dried BGS than sun-dried BGS.

Jothi et al. [63] noticed an increase in fruit number (3 fruits/plant) and yield of tomato (35.2 g/plant) with the application of BGS (obtained from the AD of a mixture containing $\mathrm{CD}$ and water at 1:1). Garg et al. [64] recovered the higher maize grain yields $\left(6.21 \mathrm{Mg} \mathrm{ha}^{-1}\right)$ and improvement in root length density $\left(1.10 \mathrm{~cm} \mathrm{~cm}^{-3}\right)$ with the treatment of BGS (at $15 \mathrm{Mg} \mathrm{ha}^{-1}$ ). Zhao et al. [65] in laboratory investigations recorded the highest germination potential, germination rate, and germination index in Vicia faba (L.) seeds soaked in $75 \%$ BGS (w/v in distilled water). Du et al. [66] worked on Hoggery BGS and observed a substantial provided; the values of $\mathrm{Ca}, \mathrm{Mg}$, and $\mathrm{Fe}$ were not reported in DBS$\mathrm{AH}, \mathrm{CM}-\mathrm{AH}$, and FYM-AH; DBS, digested biogas slurry; CM, compost manure; FYM, farm yard manure; BGS, biogas slurry; SC, slurry compost; J, reported by Jared et al. [38]; and AH, reported by Aminul Haque [12])

increase in wheat $(23.47 \%)$ and maize $(15.46 \%)$ yields. Some of the studies such as Coelho et al. [67] demonstrate that the biofertilization potential of anaerobic digestates outweighs the effect of undigested cattle slurry.

Taking a brief account of soil aggregation properties, Zheng et al. [6] experimentally examined improvement in soil structure, fertility, and $\mathrm{C} / \mathrm{N}$ distribution in red soil (Ultisol) treated with BGS (obtained from AD of pig manure and urine) and chemical fertilizer (0.45:0.55). The application of BGS can reduce the use of synthetic fertilizers up to $15-20 \%$ [10]. Lu et al. [29] found a reduction in the chemical application (NPK by 100,100 , and $26 \%$ respectively) and irrigation water use (by $45.5 \%$ ) without affecting rice grain yields in the field experimental study. Xu et al. [37] observed variable concentrations of mineral elements in different organs of $P$. frutescens. Koszela and Lorencowicza [68] fertilized soil with BGS and reported higher N (3.66\%), P (0.30\%), $\mathrm{K}(1.96 \%), \mathrm{Ca}(1.96 \%)$, and $\mathrm{Mg}(0.38 \%)$ content in Alfalfa leaves as compared to treatment that involved chemical fertilizer application. Yu et al. [69] with the application of concentrated BGS have seen improvements in the soil available NPK content while working on the tomato plant. In a similar study, Thomas et al. [70] found enhanced nitrogen and phosphorous uptake efficiency in Barley forage utilizing anaerobic beef cattle digestate (solid). In experiments of Coelho et al. [67] on ryegrass swards, soil treated with anaerobic co-digestate of food waste and pig slurry showed higher P $(4.6 \mathrm{mg} / \mathrm{L})$ than the soil treated with undigested CS $(1.5 \mathrm{mg} / \mathrm{L})$. They have also observed enhanced levels of nutrients such as $\mathrm{B}, \mathrm{Cu}, \mathrm{Zn}$, and $\mathrm{Mn}$. 


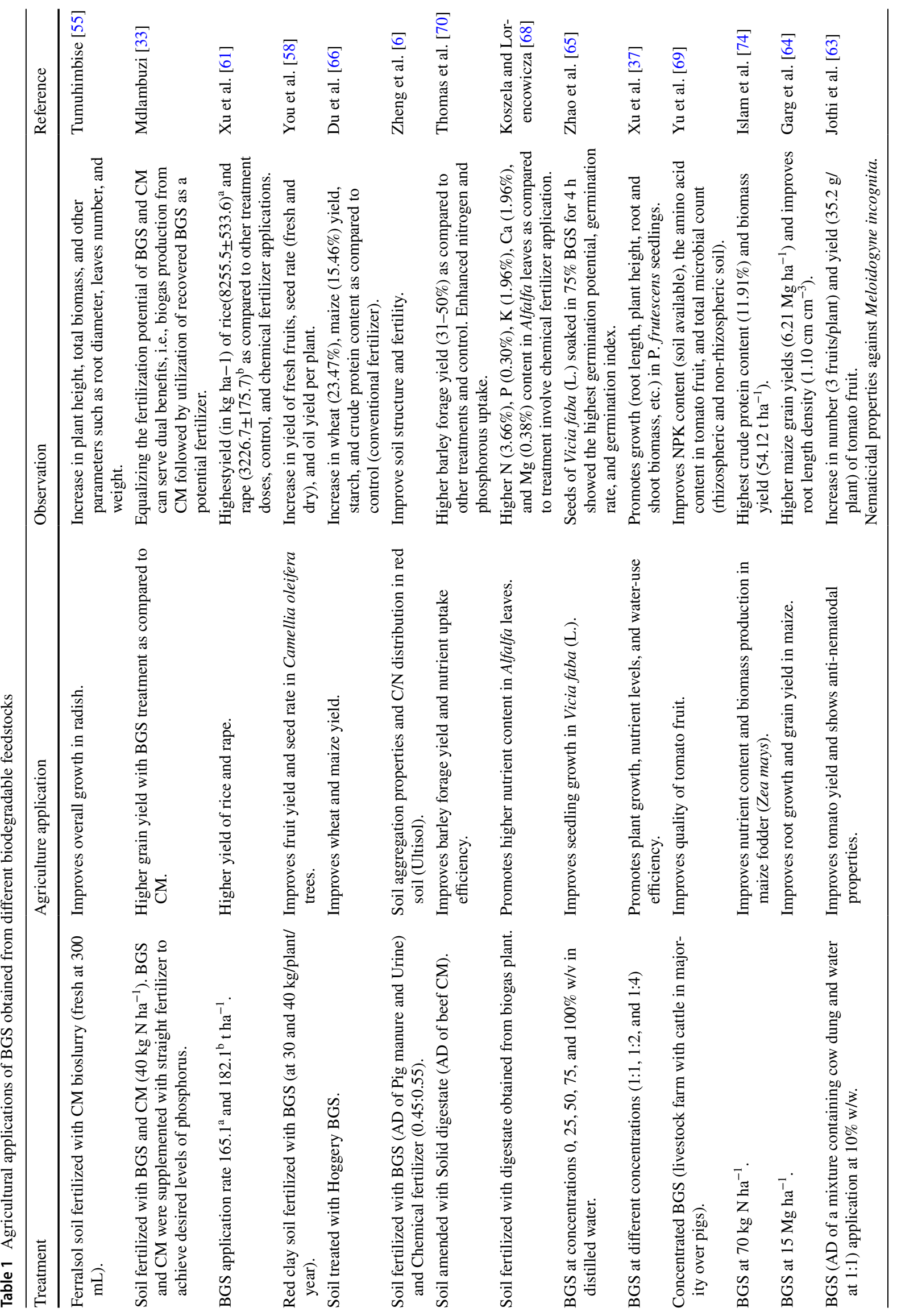




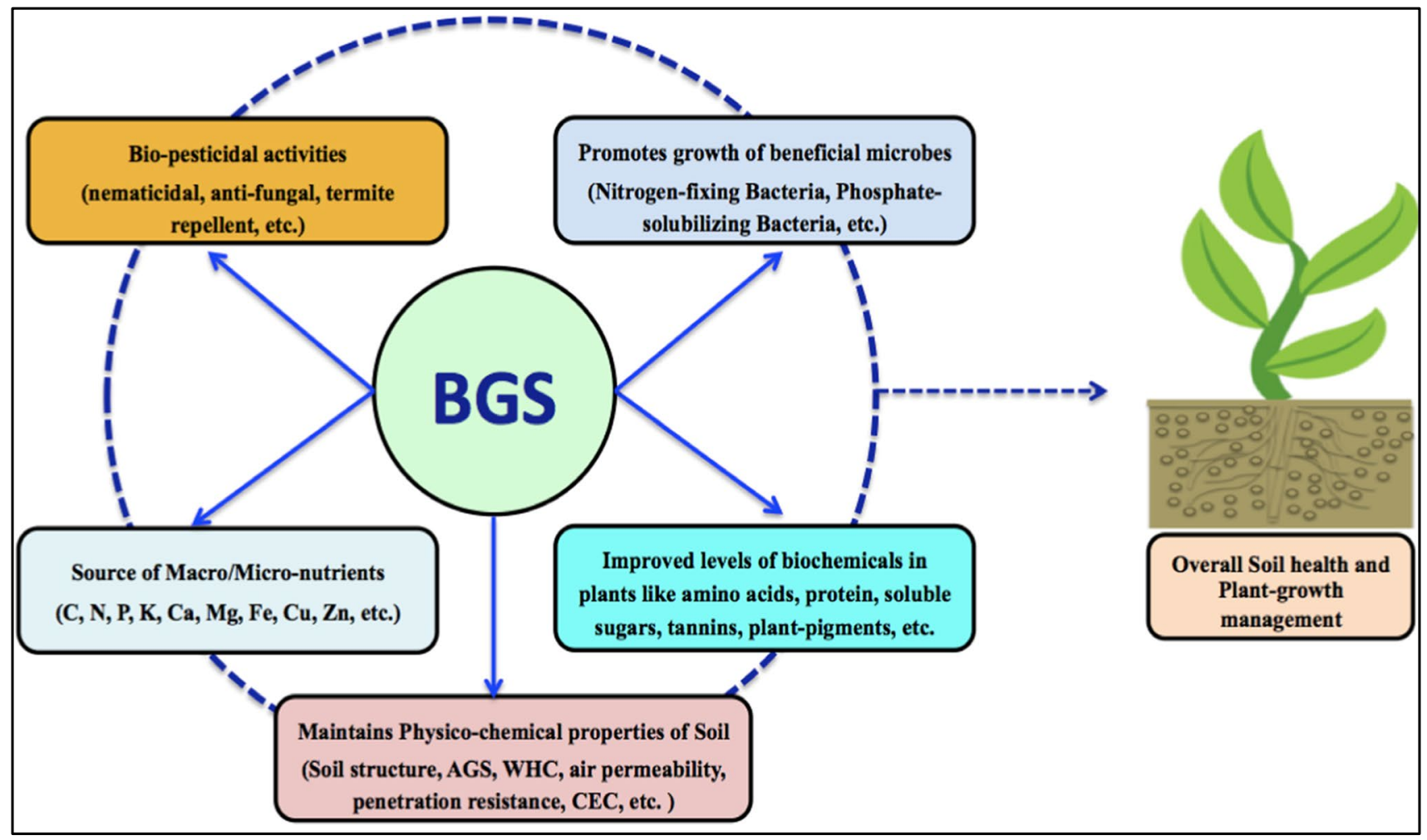

Fig. 3 Schematic representation of beneficial effects of BGS application in agriculture ( source: conceptualized from the multiple authors referred in the manuscript) (AGS, aggregate stability; WHC, water-holding capacity; CEC, cation exchange capacity)

Biopesticidal activities Moving to biopesticidal potential, BGS successfully investigated for nematicidal, anti-fungal, termite repellent, and other similar activities. BGS (called effluent by the author) repels termites, and reduces weed growth by about $50 \%$, and its compost was reported to increase $10-30 \%$ cereal crop production as compared to FYM if stored and applied properly [12]. AD of dairy manure promotes the multiplication of Bacillus species (Bacillus subtilis-B11; Bacillus licheniformis-B59) and suppressed late blight of potato [71]. Min et al. [72], utilizing anaerobically digested slurry, reported nematode control in tomato and radish. Jothi et al. [63] also observed nematicidal properties of BGS (obtained from AD of CD and water mixture in $1: 1)$ applied at $10 \% \mathrm{w} / \mathrm{w}$ in tomato against Meloidogyne incognita. Kupper et al. [73] formulated Bio1 biofertilizer from anaerobically digested CM supplemented with micronutrients (and additives for promoting fermentation) and found effectivity (at 10\% concentration) in control of citrus black spot caused by Phyllosticta citricarpa in Natal oranges, grafted on Cravo lemon trees.

Improvement in biochemicals and other utilities Du et al. [66] have seen improved levels of starch and crude protein in wheat and maize with the application of Hoggery BGS. Islam et al. [74] applied BGS (at $70 \mathrm{~kg} \mathrm{~N} \mathrm{ha}^{-1}$ ) and reported the highest crude protein content of $11.91 \%$ and biomass yield of $54.12 \mathrm{t} \mathrm{ha}^{-1}$ in Zea mays. Yu et al. [69] applied concentrated BGS and observed a higher amount of amino acids, proteins, vitamin $\mathrm{C}$, soluble sugars, tannins, and beta carotene in tomato fruits. They have also reported higher counts of culturable microbes (actinomycetes, bacteria, and fungi) in Rhizospheric and non-rhizospheric soils. In addition to this, BGS also contributes towards mitigating climate change through sequestration of Carbon in the soil [75]. Soil fertilized with anaerobic digestates offers low $\mathrm{CO}_{2}$ emission as compared to manure [48]. BGS can also serve as an organic carrier material to deliver agriculturally important microbes (AIMs). In particular, this area has been further reviewed in the Section 3 (solutions) of the manuscript.

\section{Solutions}

Various limitations associated with the BGS like low $\mathrm{C} / \mathrm{N}$ transformation rates, high TAN content, ammonia volatilization, high $\mathrm{pH}$, bulkiness, and risk of contamination imposed challenges like handling, storage, transport, and further application in agriculture fields to meet the desired benefits. Efforts have been made by the researchers to investigate the different approaches to overcome 
such ambiguities. To facilitate the systematic assessment of the available and prospective solutions, the present section has been discussed under nanotechnology-based interventions, nutrient recovery from BGS, microbially inspired, and integrated approaches. Microbes are the key drivers of agroecosystems and are known for increasing nutrient availability to plants and conferring pest and disease resistance as well. NEDOCs, apart from being a rich source of essential nutrients for crop plants, act as substrates for the beneficial microbial community that facilitates their decomposition followed by the nutrient release in soil [76]. BGS enrichment through NEDOCs and AIMs can serve multiple benefits such as balanced $\mathrm{C} / \mathrm{N}$ ratio, availability of nutrients, and growth-promoting effects to the plants. NGS platform allows comprehensive assessment of the microbial diversity in solid and liquid fractions of the digestate. Screening and selection of beneficial microbes can further be subjected to the BGS-inspired multi-substrate interaction with different organic substrates for mass multiplication of such microbes. These integrated approaches can materialize to develop different biofertilizer and organomineral-based bio-formulations. The additional processing of slurry dewatering, separation of LFD, and decontamination can also be minimized following such integrated approaches. In recent years, nanotechnology-based approaches have also been explored to bring more opportunities for the stakeholders associated with the agriculture sector. Nanoparticles are reported to have a significant influence on the microflora favoring soil nutrient mobilization [77] and recovery of nutrient-rich BGS [78]. The scope of nanotechnology-based interventions has also been explored to upgrade the fertilization potential of recovered BGS from the digesters. To provide state-ofthe-art information, this section has been taken in detail into the following sub-sections: role of nanoparticles in $\mathrm{AD}$ of biomass, nanoparticle-microbe interaction, nanoparticle co-aggregation, and environmental impacts of nanoparticle introduction into the functional system and environment. Afterward, the different methodologies of nutrient recovery from the LFD have been reviewed and recent technological developments in the area of nitrogen recovery as free ammonia and its subsequent utilization as a renewable $\mathrm{CO}_{2}$ adsorbent for biogas upgradation were also discussed. The manuscript is concluded with an overview of commercial viability and economic estimates concerning BGS. The study will be of great significance for the researchers aiming to encourage environmentalfriendly methods of developing organic formulations from biomass wastes/generated end-products to meet the current fertilizer demands and promote sustainable and circular bioeconomy through a zero-waste approach.

\subsection{Microbially inspired approaches for the enrichment of BGS}

The successful investigations on mass multiplication of AIMs in a variety of organic substrates such as DOCs, CM, and BGS not only promote the novel routes of microbial introduction in the agriculture fields but also showcase the possibilities of value addition of different organic inputs of low nutrient value. Different strategies of BGS enrichment through microbially inspired routes have been reviewed in this section. Taking account of another key aspect, i.e., the microbial community dynamics of methanogens, little information is available on the unculturable microbes supporting $\mathrm{AD}$ of organic matter leading to biogas production [40]. However, advancement in molecular biology techniques such as NGS will be useful in depicting microbial community structures (diversity and richness) through taxonomic assignments (QIIME analysis), alpha diversity analysis (Shannon index, Simpson index, ACE, Chao1 index, and observed species), and others. The microbial community analysis reported in $\mathrm{CD}, \mathrm{CM}$, and BGS and the potential role of the identified microflora in crop improvement have been reviewed. Furthermore, integrated approaches of combining BGS with other organic inputs (NEDOCs) to exploit the microbial community dynamics through multi-substrate interactions have also been discussed.

\subsubsection{Microflora associated with biogas feedstocks and BGS}

Microbial diversity analysis $16 \mathrm{~S}$ ribosomal sequencing studies allow diversity and dynamics analysis of uncultured microbes inhabiting the environmental niches $[79,80]$. Integration of advanced "Omics" technologies permits detailed investigation of microbial community structures in varied habitations including biogas digesters containing biomass feedstocks. Han et al. [81] reported bacterial and archaeal community diversity in household rural biogas digesters fed with different raw materials such as vegetable waste, pig manure, and a mixture of other waste materials. The most abundant phyla reported were Bacteroidetes, Firmicutes, and Proteobacteria.

Application of BGS has substantial effects on the microbial population (Rhizospheric and non-rhizospheric soil) [69]. CD, one of the common feed substrates in biogas production, harbors diverse microbiota. CD consists of $80 \%$ water, $14.4 \%$ undigested matter, and $5.6 \%$ of a microbial community comprising fungi, bacteria, and actinomycetes [82]. Sun et al. [83] reported Firmicutes as the dominant phylum in cow manure and the operational taxonomic units (OTUs) were 270-274. The Shannon Diversity, Chao1, and Simpson indices recorded by them were 6.361 to $6.167,358$ 
to 420 , and 0.957 to 0.971 respectively for the bacterial population and 2.081 to $2.404,22$ to 27 , and 0.648 to 0.693 for Archaeal population in cow manure. BGS reportedly support bacterial populations such as Proteobacteria, Chloroflexi, Firmicutes and Bacteroidetes [40], Bacillus spp., Carnobacterium spp., [60], P. fluorescence, Nomuraea rileyii, Verticillium lecani, Fusarium-15, and Trichoderma viride [59]. Christy et al. [84] isolated Acetobacter syzygii, Bacteroides nordii, Clostridium perfringens, Methanobacterium formicicum, Lactobacillus acidophilus, Methanosarcina siciliae, Prevotella bivia, Porphyromonas asaccharolytica, and Prevotella bivia from bioreactor (fed with CD slurry).

$\mathrm{Xu}$ et al. [61] performed alpha diversity analysis of bacterial population in soil fertilized with BGS, chemical fertilizer (NPK for rice: $0.006,0.10,0.07 \mathrm{t} \mathrm{ha}^{-1}$ respectively; NPK and boron for rape: $0.25,0.27,0.19,0.007 \mathrm{t} \mathrm{ha}^{-1}$ respectively), and control (soil without treatment). They have recorded higher Chao1 index values in sampled soil enriched with a low dose of BGS $\left(59.9 \mathrm{t} \mathrm{ha}^{-1}\right)$ as compared to its higher dose $\left(264.4 \mathrm{t} \mathrm{ha}^{-1}\right)$. The decreasing order of Chao1 index in sampled soil was as follows: BGS low dose $59.9 \mathrm{t} \mathrm{ha}^{-1}(39,552-44828)>$ chemical fertilizer treatment $(38,869-41,143)>$ control $(37,068-41,756)$. The values obtained by them for Shannon Index were 10.80-12.22 for BGS (at 59.9 $\mathrm{t} \mathrm{ha}^{-1}$ ), 10.97-12.05 for chemical fertilizer treatment, and 10.44-12.46 for control. Compared to control, the abundance of Acidobacteria, Chloroflexi, Planctomycetes, Verrucomicrobia, Nitrospirae, and AD3 was relatively higher in BGS treatments. The alpha diversity indices for microbial community analysis associated with BGS are in Table 2.

\section{Application of microbes (associated with BGS and biogas} feedstocks) in agriculture Lu et al. [88] identified 17 bacterial strains from CD ((Alcaligenes faecalis CD232, CD243, CD257, CD261, CD205), Bacillus cereus (CD9, CD98, CD260), Microbacterium aerolatum (CD142), $P$. otitidis (CD237), P. beteli (CD204), P. aeruginosa (CD245), Providencia rettgeri (CD256), Proteus penneri (CD129, CD212), Staphylococcus xylosus (CD250), and Staphylococcus sciuri (CD97)) (out of 219 isolates) that showed anti-nematodal activity (greater than $90 \%$ within $1 \mathrm{~h}$ ) against Caenorhabditis elegans. Except Alcaligenes faecalis CD205, P. otitidis CD237, and $P$. aeruginosa CD245, volatile compounds of the remaining 14 bacterial isolates exhibited nematicidal activity against Meloidogyne incognita. Bacillus licheniformis isolated from CD (fermented with basalt dust and eggshell) showed IAA production $\left(1.75 \mu \mathrm{gmL}^{-1}\right)$, phosphorous solubilization ( $2.37 \%$ in 10 days), and antagonistic activity against plant fungal pathogen (Rhizoctonia bataticola) [89].
Bioinoculants with multiple properties can be preferred in agriculture fields. Paikray and Malik [90] in a US patent application disclose a synergistic composition of at least seven beneficial bacteria ( $P$. fluorescens, $P$. striata, Azospirillum, Azotobacter, Bacillus subtilis, Bacillus polymyxa, and Lactobacillus); at least two beneficial fungi (Trichoderma herzianum, T. viride); at least one yeast (Saccharomyces cerevisiae); and at least one compound which extends the effective lifetime of said formulation. Game et al. [91] studied the efficacy of microbial consortium (Bacterial isolate B-28 (Bacillus spp.), fungal isolate F-13 (Aspergillus terreus), and Actinomycetes isolate A-40 (Streptomyces sp.)) for composting of rural (farm waste, animal litter, animal fodder waste, dung) and urban wastes (vegetable waste, kitchen waste, roadside waste, papers, etc.) and reported the reduction in composting time coupled with nutrient enrichment in compost derived from both the waste types as compared to the commercial consortium and uninoculated controls.

BGS in combination with different organic amendments reported to support the population of bio-control agents such as $P$. fluorescence, Verticillium lecani, Trichoderma viride, and Metarhizium anisopliae [59]. Kavya et al. [92] reported an increase in the growth of beneficial microorganisms (Rhizobium, Pseudomonas, Azotobacter, Azospirillum) on different combinations of substrates $(\mathrm{CD}$, press mud, poultry litter, kitchen wastes, maize stalks, and fruit wastes) utilized for biogas production and observed that the different organic substrates supported the microorganism's growth for at least 3 to 4 weeks of duration. Karmegam and Rajasekar [93] studied the strategies for enriching BGS vermicompost with Azotobacter chroococcum and Bacillus megaterium.

Soil available nutrient through the application of organic matter relies upon the catabolic potential of microflora [94]. The viability and an adequate load of microorganisms are important to get appropriate results in the agriculture fields. Bioinoculant success depends upon the survival of microbial strain in the soil, more prominently under adverse agro-climatic conditions such as temperature variations and $\mathrm{pH}$ range. Scientists and biofertilizer producers are also facing the same challenges to increase the effectiveness of biofertilizers under variable geographic and agro-climatic conditions [1]. The development of stress resistance in microbial strains through phenotypic adaptations (permanent and non-revertible) is preferred over genetically manipulated strains (gene transfer) due to environmental hazards associated with the introduction of genetically modified organisms [1]. Thus, studies pertaining to the selection and application of suitable bio-inoculants (with respect to soil nature, agro-climatic condition, crop variety, etc.) and microbial formulations coupled with soil texture profiling to tune up with microbial growth must be taken up further [1]. 


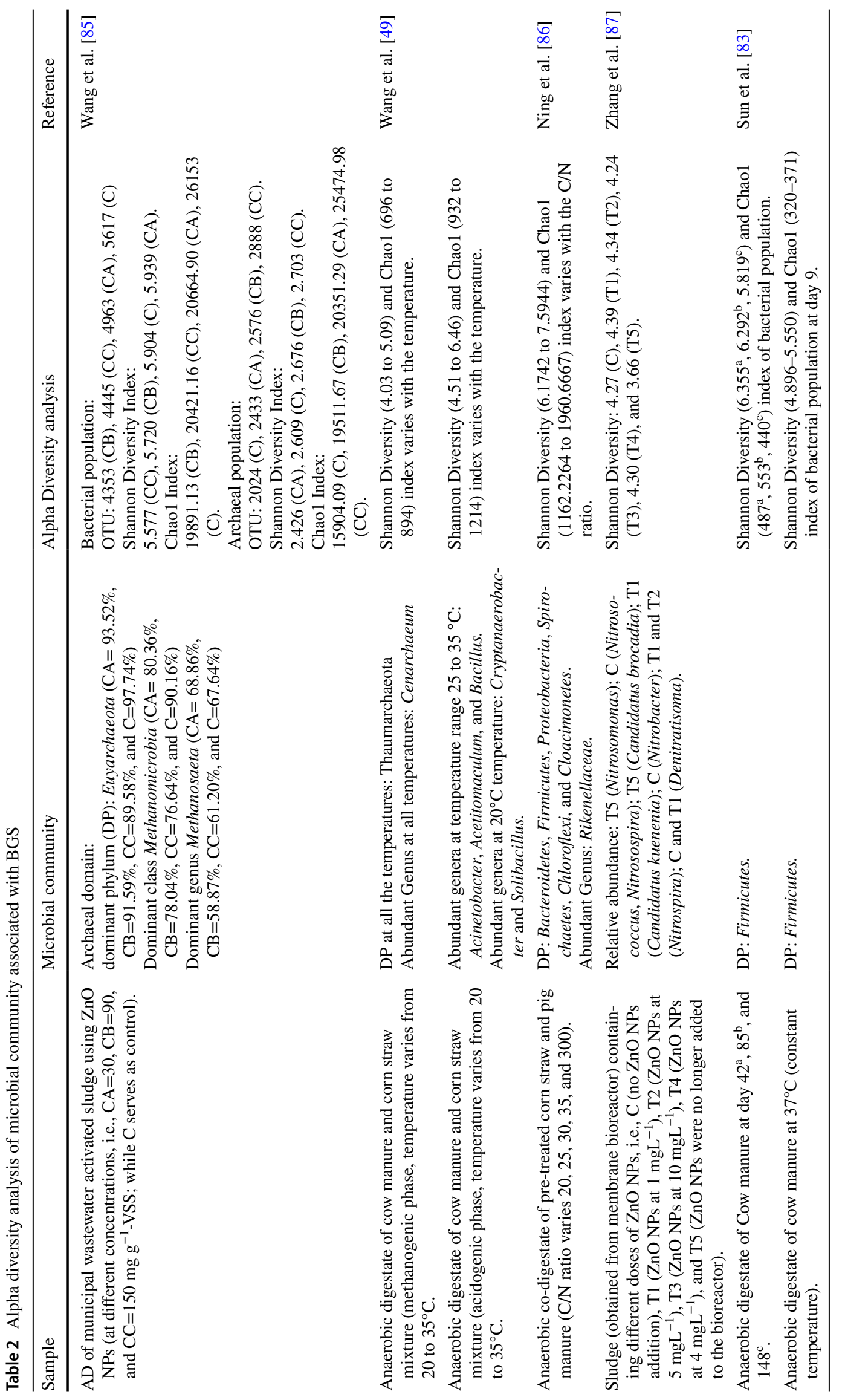




\subsubsection{NEDOCs: potential substrates for mass multiplication of AIMs}

BGS can combine with the organic substrates of high nutrient values like NEDOCs. The combination of BGS and NEDOCs complements each other in terms of improving their properties (such as balanced $\mathrm{C} / \mathrm{N}$ ratio and moisture content), which can also be productive for the mass multiplication of AIMs. Besides this, the addition of NEDOCs potentially reduces the requirement of dewatering in BGS, hence aiding convenience in storage and handling for field applications. This is a key aspect as the process of drying BGS to reduce water content is reported to have low nitrogen levels as compared to the fresh BGS (wet) [9]. Thus, the addition of NEDOCs to some extent can reduce the necessity of additional treatments of BGS (to reduce water content) and could be beneficial to sustain the nutrient levels in BGS, which are probably lost at the time of drying.

The major fraction of seed cakes is reportedly rejected as toxic, and remains unutilized [95]. India has over 100 species of non-edible oil seed-bearing plants [96, 97], out of which presently 10-12 varieties have been explored until now [97]. Around 70\% of oiled cake has been recovered after expelling oil from the tree-borne oilseeds [96]; hence, the availability of the DOCs can be estimated from such figures. Marathe and Deshmukh [96] while highlighting the oilseed production potential in India mentioned the non-edible oilseed cakes quantity of about 2.812 MMTs. However, as cited by Prasad [98], an evaluation of the exact quantity of non-edible oilseed cakes (NECs) is insignificant.

Table 3 shows the nutrient compositions of different non-edible seed cakes published in the previous reports. NEDOCs of Azadirachta indica contain N, P, K, Ca, Zn, Fe, etc., [99]; similarly, nutrients reported in $P$. pinnata DOCs were $\mathrm{C}, \mathrm{N}, \mathrm{P}, \mathrm{K}, \mathrm{Ca}, \mathrm{Mg}, \mathrm{S}$ (macronutrients), $\mathrm{Zn}, \mathrm{Fe}, \mathrm{Cu}$, and $\mathrm{B}$ (micronutrients) [39, 100]. Jared et al. [38] found higher $\mathrm{Mn}, \mathrm{Zn}, \mathrm{Ca}$, and $\mathrm{Fe}$ in slurry compost as compared to BGS, though the NPK levels were greater in BGS. As the microbes play an important role in the process of composting [101], the higher nutrient availability can be attributed to the undergoing microbial actions. Microbial biofertilizers have significant potentials for biological nitrogen fixation: nutrient recycling, solubilization, and mobilization, etc. [102]. NEDOCs have also been investigated for supporting the population of agriculturally beneficial microbes [103, 104]. Optimization of BGS and DOC combination for mass multiplication of AIMs followed by application of developed biofertilizer formulations in agriculture fields can strategically favor the soil nutrient profile and higher crop yields.

The presence of toxic compounds in NEDOCs limits their applications in the agriculture fields. Decomposition substantially reduces the presence of toxic compounds present in DOCs. Das et al. [106] through co-composting of Jatropha DOC (J-DOC) and animal dungs considerably reduced the Phorbol ester content. Incorporating AIMs further improves the efficiency of decomposition followed by the metabolization of such toxic compounds. Researchers successfully utilized the NEDOCs as low-cost substrates for the multiplication of biocontrol agents, growth-promoting microbes, and developing different bioformulations [39, 76, 108-115]. According to Singh et al. [69], the utilization of DOCs as substrates for the multiplication of beneficial microbes facilitates soil fertility under field conditions coupled with reducing the risk of disease occurrence. Tomer et al. [112] mentioned the role of allelochemicals behind the prevention of various soil-borne diseases through the combined application of DOCs and microbial bio-control agents.

Studies in the area of screening, identification, and separation of bioactive compounds produced by the AIMs utilizing DOCs and BGS could be beneficial in developing formulations of potential biocontrol activities. The approach seems to be more conceivable if we look upon the findings of Sharma et al. [108], Arora et al. [109], and Sharma et al. [116]. Sharma et al. [108] multiplied Purpureocillium lilacinum 6029 on Karanja DOC (K-DOC) and the metabolites of potential biocontrol activity identified by them were benzene acetic acid, benzoic acid, phenyl ethyl alcohol, 2-ethyl butyric acid, and 3,5-di-t-butylphenol. The first report on the presence of butyric acid (possesses nematicidal activities) in $P$. lilacinus filtrate was predicted to be the result of metabolic pathways elicited in response to their growth (during submerged fermentation) on K-DOC [116]. Arora et al. [109] optimized K-DOC, J-DOC, and dextrose combination $\left(4.5,12.5\right.$, and $10 \mathrm{gL}^{-1}$ respectively)
Table 3 Nutrient compositions of different non-edible seed cakes

\begin{tabular}{ll}
\hline DOCs & Nutrient composition \\
\hline Karanja & C: $42.26 \pm 2.4 \% ; \mathrm{N}: 4.87 \pm 0.87 \% ; \mathrm{P}: 0.89 \pm 0.03 \% ; \mathrm{K}: 1.3 \pm 0.02 \%$ [39]; Ca: \\
& 0.25\%; Mg: 0.17\%; Zn: $59 \mathrm{ppm} ; \mathrm{Fe}: 1000 \mathrm{ppm}$ Cu: $22 \mathrm{ppm} ; \mathrm{Mg}: 74 \mathrm{ppm} ; \mathrm{B}:$ \\
& $19 \mathrm{ppm}$; and S: $1894 \mathrm{ppm}[100]$ \\
Neem & $\mathrm{N}: 4.51 \% ; \mathrm{P}: 0.79 \% ; \mathrm{K}: 1.40 \% ; \mathrm{Zn}: 57 \mathrm{ppm} ; \mathrm{Ca}: 1.40 \mathrm{ppm} ; \mathrm{Fe} 640 \mathrm{ppm}$ [99] \\
Mahua & $\mathrm{C}: 44.93 \pm 0.08 \% ; \mathrm{N}: 3.15 \pm 0.02 \%[105]$ \\
Jatropha & $\mathrm{N}: 2.93 \pm 0.06 \% ; \mathrm{P}: 9623 \pm 109 \mathrm{ppm} ; \mathrm{K}: 8563 \pm 157 \mathrm{ppm} ; \mathrm{C} / \mathrm{N}: 10.2 \pm 0.10[106]$ \\
Castor & $\mathrm{N}: 75.4 \mathrm{gkg}^{-1} ; \mathrm{P}: 31.1 \mathrm{gkg}^{-1} ; \mathrm{K}: 6.6 \mathrm{gkg}^{-1} ; \mathrm{Ca}: 7.5 \mathrm{gkg}^{-1} ; \mathrm{Mg}: 5.1 \mathrm{gkg}^{-1}[107]$ \\
\hline
\end{tabular}


for the growth of Paecilomyces variotii and reported dipicolinic acid (DPA) production 2.5 times higher as compared to the basal medium. The effectiveness of DPA in regulating rhizospheric phytopathogens has also been reported. In this way, not only the wide range of NEDOCs; the other biomass wastes such as BGS can also be exploited to develop a rich repository of compounds derived from AIMs through multisubstrate interactions.

The low levels of NPK or other nutrients in the cattle feed could have been reflected in the $\mathrm{CM}$ and consequently in the recovered BGS. Under such conditions, BGS alone will be unable to fulfill the entire nutrient demands as a fertilizer. To balance the phosphorus levels in BGS, Mdlambuzi et al. [33] added superphosphate. However, possibilities of such amendments can also be possible through the enrichment with DOCs and AIMs (such as phosphate-solubilizing bacteria). The $\mathrm{C} / \mathrm{N}$ content is critical in the investigations dealing with the suitability of different substrate(s) to achieve higher microbial growth. Sharma et al. [110] optimize the C/N ratio of 40:1 $(\mathrm{pH}=7)$ in K-DOC (using sucrose as carbon source) for the growth of P. lilacinus. Sharma et al. [39] have attempted to replace the sucrose with BGS (sun-dried) as a potential carbon source (required for microbial growth under SSF). The recorded values of $\mathrm{C} / \mathrm{N}$ ratio for $\mathrm{K}-\mathrm{DOC}$ and $\mathrm{BGS}$ (sun-dried) were $8.68 \pm 0.11$ and $57.78 \pm 0.19$ respectively [39]. In concerned with their suitability favoring microbial growth, the $\mathrm{C} / \mathrm{N}$ ratio appears to be high in K-DOC and low in sun-dried BGS. The authors [39] reported K-DOC/ BGS ratio of 60/40 as optimal for P. lilacinum 6029 multiplication under SSF. In co-composting of Jatropha DOCs and rice straw mixture (1:9) $(\mathrm{OM})$ with different animal dungs (buffalo dung (BD), cow dung (CD), goat dung (GD), horse dung (HOD), and hen droppings (HED)), Das et al. [106] recorded the highest $\mathrm{C} / \mathrm{N}$ ratio in $\mathrm{OM}+\mathrm{CD}(20: 1)$. Upon optimizing the $\mathrm{OM}$ and animal dung proportions, the $\mathrm{OM}+\mathrm{BD}, \mathrm{OM}+\mathrm{GD}, \mathrm{OM}+\mathrm{HED}$, and $\mathrm{OM}+\mathrm{HOD}$ in the combination of 20:1, 10:1, 5:1, and 5:1 respectively showed the highest $\mathrm{C} / \mathrm{N}$ ratio (Fig. 4). Thus, as compared to other animal dungs, $\mathrm{CD}$ contributes maximum $\mathrm{C} / \mathrm{N}$ ratio and undoubtedly emerges as an ideal ingredient to directly or indirectly (after resource generation such as BGS) utilized with other organic substrates for the mass multiplication of AIMs. Such studies certainly pave the way ahead to explore the diverse range of carbon-rich biomass wastes with the potentials of replacing expensive carbon sources.

\subsection{Integrated approaches}

This section entails the utilization of BGS for agricultural applications through enrichments via multi-component organic substrates, vermicomposting, NPK amendments, etc. Alongside, methodologies to overcome the contamination risks (pathogens, heavy metals, pesticides, and other organic pollutants) and handling a liquid fraction of BGS were also taken into consideration; hence, the said subsection is entitled as integrated approaches.

Taking account of growth-promoting activities of the BGS-AIM combination, Hamid et al. [117] recorded an overall improvement in growth, yield, and physiology of sunflower under moderate salinity stress with the application of BGS enriched with B. subtilis Y16 strain. Ahmad et al. [118] also noticed improvements in maize growth under salt stress using BGS supplemented with biofertilizer and 100\% recommended dose of nitrogen. Gao et al. [119] reported an
Fig. $4 \mathrm{C} / \mathrm{N}$ ratio under optimized combinations of $\mathrm{OM}$ with different animal dungs (refer text for the details of abbreviations used) [106]

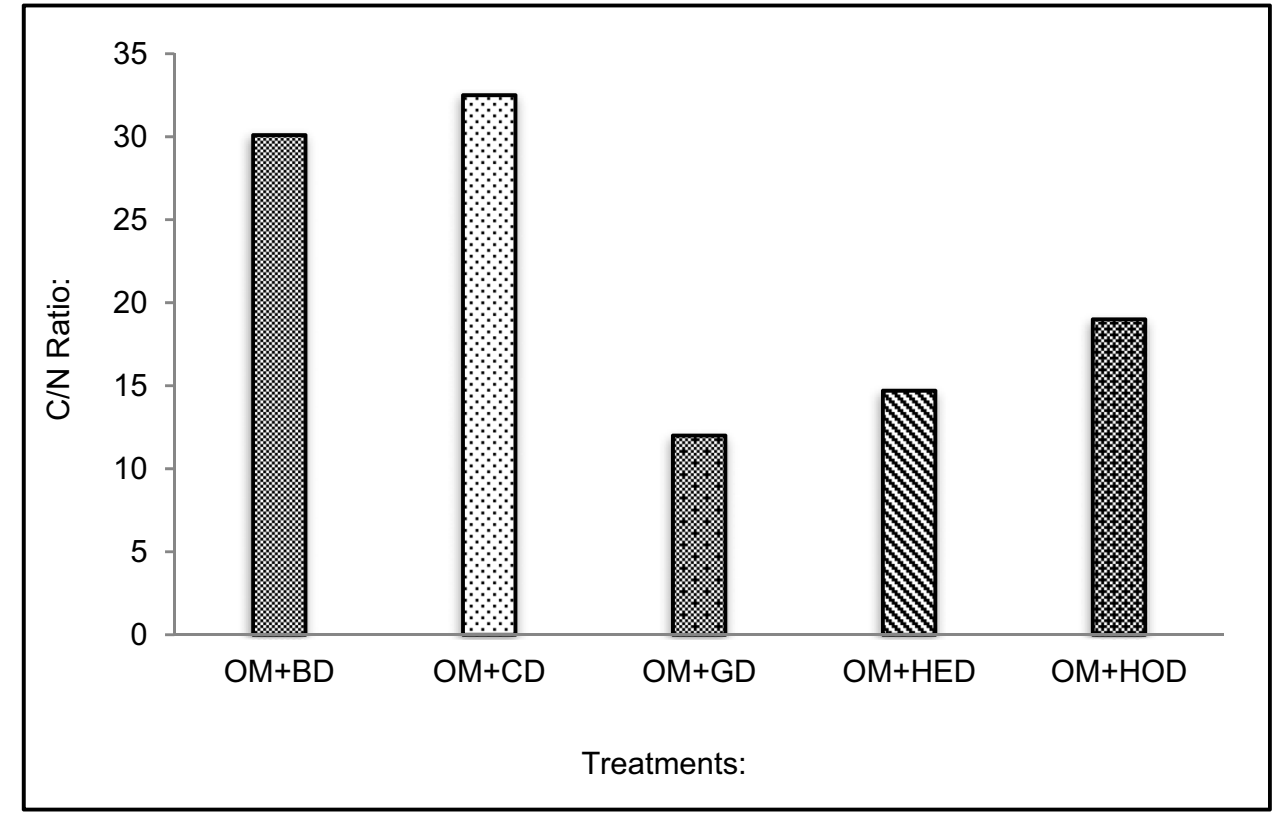


increase in mycorrhizal colonization, rhizospheric bacterial count, and overall growth in maize using formulation containing BGS, biofertilizer, and 50\% NPK. Sharma et al. [39] developed a fungal formulation (P. lilacinum) using K-DOC and sun-dried BGS (60:40) as a substrate for nematode control. Devakumar et al. [59] also utilized multi-substrateenriched BGS for the multiplication of biocontrol agents such as $P$. fluorescence and Trichoderma viride. In an experiment, soil samples were collected from BGS-cultivated (paddy) (BCL) and chemically cultivated lands (CCL) and found $23.3 \%$ higher bacterial counts in BCL as compared to CCL [36]. Thus, BGS application supports a favorable environment for microbial growth in agriculture fields.

Treatment of BGS has a significant influence on enzymatic regulation, cellular development, and photosynthetic induction [119]. Organic or mineral enrichments could be helpful to reduce the bulkiness of BGS and increase its application as fertilizer in agriculture [7]. Notably, performing anaerobic co-digestion (ACD) of $\mathrm{CM}$ with other carbonrich organic substrates (balanced $\mathrm{C} / \mathrm{N}$ ratio) promotes microbial activity, thereby improving biogas yield and recovery of nutrient-rich digestate.

Vermicomposting of BGS significantly reduces the C/N ratio (above $80 \%$ as compared to an untreated BGS recorded by Yadav et al.) [120], which supports its application in agriculture as a potential organic nutrient input. They have reported higher TKN values $\left(\mathrm{g} \mathrm{kg}^{-1}\right)$ with vermicomposted BGS $(29.90 \pm 2.10)$ as compared to an untreated slurry $(6.20 \pm 0.25)$. The microbial diversity of vermicompost can also be explored for the value addition of BGS. Hao et al. [121] in their investigation observed that the bacterial communities associated with the vermicompost showed metabolic competence for the upgradation of swine manure compost. Decline in Stenotrophomonas and Acinetobacter (genera of phylum Proteobacteria known for pathogenic bacteria) and rise in Chryseolinea and Actinomadura genera (beneficial microbes) were also noted. The 30th-day inoculation of $A$. chroococcum at the rate of $30 \mathrm{~mL}, 35 \mathrm{~mL}$, and $40 \mathrm{~mL}$ per $175 \mathrm{~g}$ of vermibed substrate (composted $B G S$ ) showed survival up to 105 days ( $\mathrm{cfu} 2 \times 10^{7} \mathrm{~g}^{-1}$ ), 135 (cfu 1 $\times 10^{7} \mathrm{~g}^{-1}$ ) days, and 135 days $\left(\mathrm{cfu} 2 \times 10^{7} \mathrm{~g}^{-1}\right.$ ) respectively [93]. In the case of B. megaterium, they found that the 30thday inoculation at the rate of $30 \mathrm{~mL}, 35 \mathrm{~mL}$, and $40 \mathrm{~mL}$ per $175 \mathrm{~g}$ of vermibed substrate showed survival up to 150 days (cfu $2 \times 10^{7} \mathrm{~g}^{-1}$ ), $165\left(\right.$ cfu $1 \times 10^{7} \mathrm{~g}^{-1}$ ) days, and 165 days $\left(\right.$ cfu $\left.2 \times 10^{7} \mathrm{~g}^{-1}\right)$ respectively.

Extracts of T. brownii leaves and barks of Acanthaceae spp. (at 5\% v/v separately) added to biogas substrate (67\% kitchen waste and 33\% of CD and goat dung in 1:1) reported increasing biogas yields and nutrient content (TKN, TAN, TS, TP, etc., in the case of $T$. brownii leaves extract; and $\mathrm{K}$, $\mathrm{Ca}, \mathrm{NO}_{3}{ }^{-}, \mathrm{PO}_{4}{ }^{3-}, \mathrm{SO}_{4}{ }^{2-}$ in the case of Acanthaceae spp. bark extract) in BGS [122]. Zhang et al. [123] performed
$\mathrm{ACD}$ of rice straw and combined swine manure-urea mixture in 7:3 (C/N ratio 24.23) and observed higher biogas production coupled with improving fertilization value of recovered digestate as compared to other treatments and control. The authors stated that the urea addition could foster the lignin degradation, hasten the process of hydrolysis, and improve $\mathrm{N}$ content in the digestates.

Partial replacement of chemical fertilizers with BGS has also been reported in a few studies for fertigation purposes. BGS enriched with variable doses of NPK promotes growth and pod yield in the pea plant [124]. As compared to fertilizer control, Jamison et al. [125] observed a slight increment in nutrient uptake and use efficiency in Brassica juncea using lignocellulosic biomass digestate supplemented with commercial liquid fertilizer. Do and Scherer [126] witnessed higher ryegrass yield using hygromull-enriched anaerobic digestate. Fraire García et al. [127] observed an increase in maize and tomato yields in Ultisol soil fertilized with BGS (enriched with recommended fertilizer dose). Xu et al. [9] found improvement of forage and biomass quality in Lolium multiflorum with partial replacement of chemical fertilizers (CFs) with BGS. Supplementation of BGS $(100.5 \mathrm{~kg}$ $\left.\mathrm{ha}^{-1}\right)$ with $\mathrm{CF}\left(37.5 \mathrm{~kg} \mathrm{ha}^{-1}\right)$ was reported to increase crude fiber and crude protein content in L. multiflorum by $10.00 \%$ and $10.35 \%$ respectively as compared to CF treatment alone $\left(112.4 \mathrm{~kg} \mathrm{ha}^{-1}\right.$ ) (NPK content in BGS: $0.23 \%, 0.05 \%, 0.32 \%$ respectively; in CF: $11.34 \%, 7.56 \%, 7.56 \%$ respectively). Refer to Table 4 for more applications of enriched BGS in agriculture.

Apart from this, while handling the BGS, its management is also important to prevent the loss of nutrients at the time of application [53]. The BGS applied in agricultural fields is majorly acquired from biogas digesters operated with feedstock sources like livestock slurry (LSS), anaerobic co-digestates of LSS, and plant biomass or biomass waste such as agriculture residues. The recovered BGS is either applied directly or in supplementation with micronutrients, chemical fertilizers, etc. In such instances, the likelihood of meeting expected benefits primarily depends upon the handling, storage, and mode of the BGS application. The effectiveness of different application modes (such as root irrigation and spraying) also needs to be investigated [69]. Higher nutrient concentration can result in the accumulation of ions at the intercellular level, damage chloroplast structure, and consequently, decrease in chlorophyll content and photosynthetic rate [37]. Therefore, further studies leading to the optimization of effective dose with reference to the application mode, soil nutrient profile, plant's requirement, etc., are hereby suggested.

Another emerging challenge with the BGS (precisely obtained from animal manures, urine, and different waste streams as feedstock material for AD) is the likelihood of pathogens, heavy metals, pesticides, etc., which further 


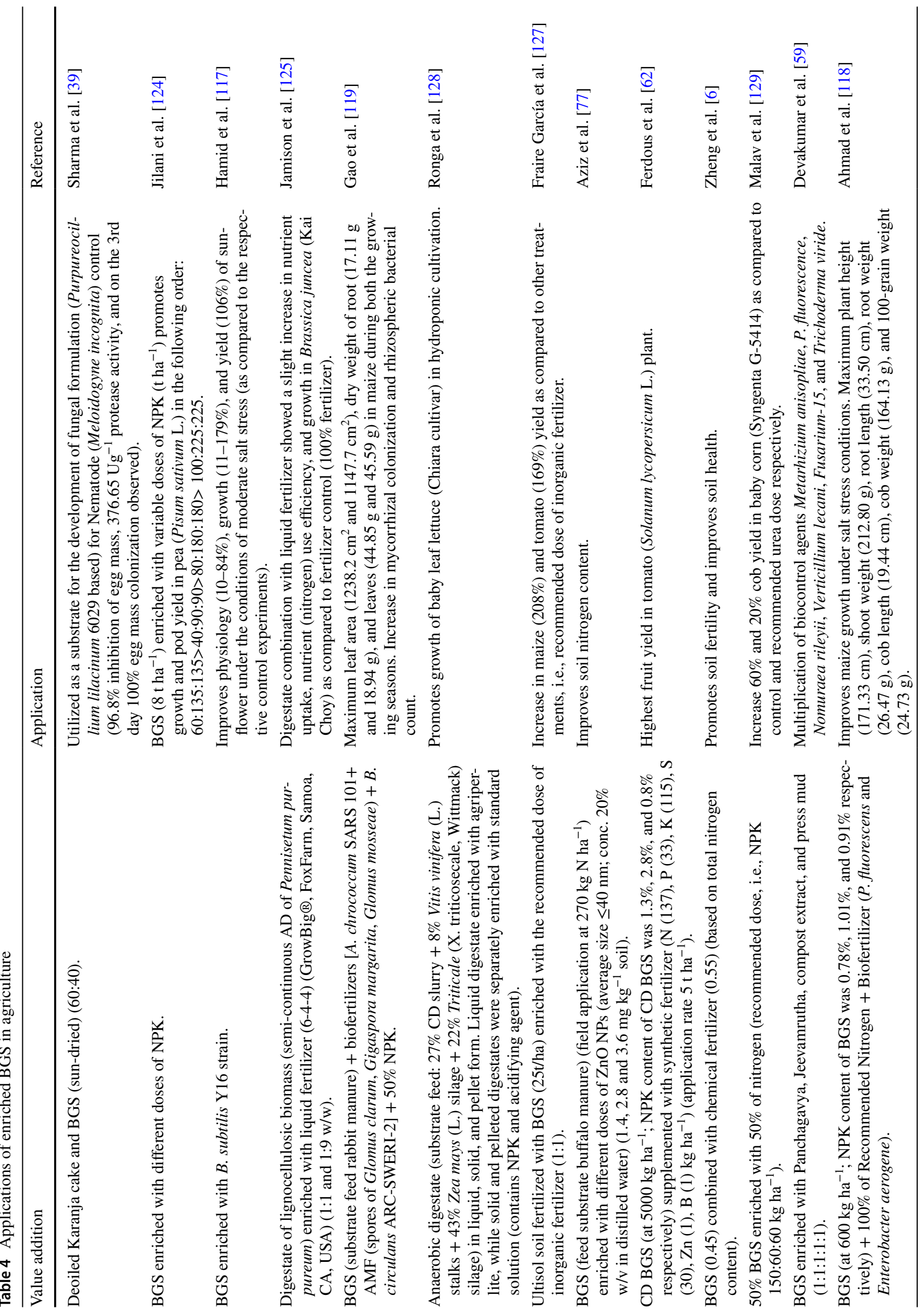


contaminates soil and plants when applying directly to the crop fields. It is suggested that in cases where BGS applied to the vegetables and fruits that are consumed fresh, they must be washed well before consumption [17]. The risk of pathogens can be reduced through proper treatment of BGS (optimal retention time, temperature, etc.) [14]. Appropriate dilutions before field applications can further reduce the toxicity risk as a consequence of the higher concentration of ammonia and soluble $\mathrm{P}$, presence of heavy metals, pathogens, and other contaminants. As mentioned earlier, the process of AD does not degrade heavy metals [27]; however, their solubility and availability can decrease (due to precipitation, struvite production, etc., depending upon metal type) [21]. With BGS application, the use of metal-immobilizing materials can play a substantial role in mitigating the potential risk of heavy metal pollution [27]. However, further studies are duly recommended to explore such possibilities.

\subsection{Nanotechnology-based interventions}

Nanoparticles offer a large surface-area-to-volume ratio, thus are reported to have no impact on chemical properties of soil (such as $\mathrm{pH}$, electrical conductivity) when applied in combination with organic matter (such as anaerobic digestates) or alone [77]. Nanoparticles are also found to influence the microbiota and extracellular enzyme secretion in the soil thus favoring soil nutrient mobilization [77, 131]. Nanoparticle treatment has been reported to enhance biogas production through the increased activity of bacteria degrading organic matter anaerobically and the resulting waste can be utilized as quality compost [78]. Table 5 shows the role of NPs in biogas production from organic feedstocks such as livestock, phyto-biomass, and sludge/wastewater. The idea was to give an overview (based on the latest findings) of how nanoparticle dose, type, and their interaction with feedstock substrates and microbial community during AD affect the yield and quality of biogas production.

Apart from NPs, trace elements/bulk materials/mineral accelerants (such as iron oxide, copper oxide, zinc oxide, copper chloride, cobalt chloride, iron oxide-zeolite, magnetite, $\mathrm{Fe}^{2+}$ (as $\mathrm{FeCl}_{2} \cdot 4 \mathrm{H}_{2} \mathrm{O}$ ), $\mathrm{Ni}^{2+}$ (as $\mathrm{NiCl}_{2} \cdot 6 \mathrm{H}_{2} \mathrm{O}$ ), $\mathrm{Fe}-\mathrm{Co}$, $\mathrm{Fe}-\mathrm{Ni}, \mathrm{Fe}-\mathrm{Co}-\mathrm{Ni}$, cupric sulfate, cupric glycinate, vermiculite, limonite, bentonite, waste iron powder, zvi powder, fly ash, clinoptilolite) have also reported improvements in the biogas/methane yield during AD of biomass [132-147]. We suggest further readings [148] to get more information on the role of trace elements $(\mathrm{Cu}, \mathrm{Co}, \mathrm{Fe}, \mathrm{Mn}, \mathrm{Mo}, \mathrm{Ni}, \mathrm{Se}, \mathrm{W}$, $\mathrm{Zn}, \mathrm{V}$ ) in different enzymes that take part in AD. The addition of trace elements/mineral accelerants during $\mathrm{AD}$ was also reported to improve fertilization values of recovered digestate, as observed by Xu et al. [134] in the case of vermiculite addition (as mineral accelerant). The biostimulation (BSM) of methanogens during AD through laser irradiation 


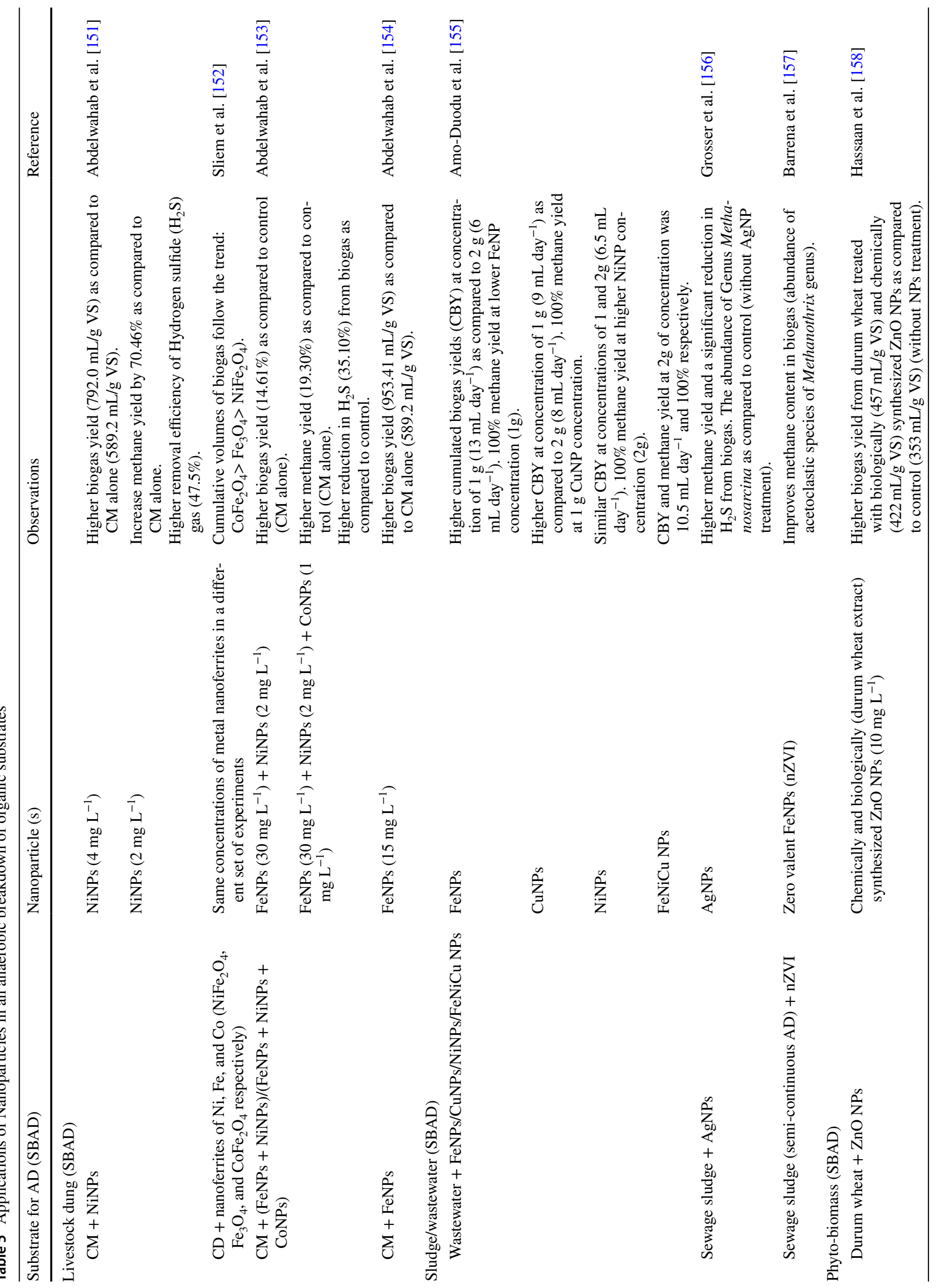




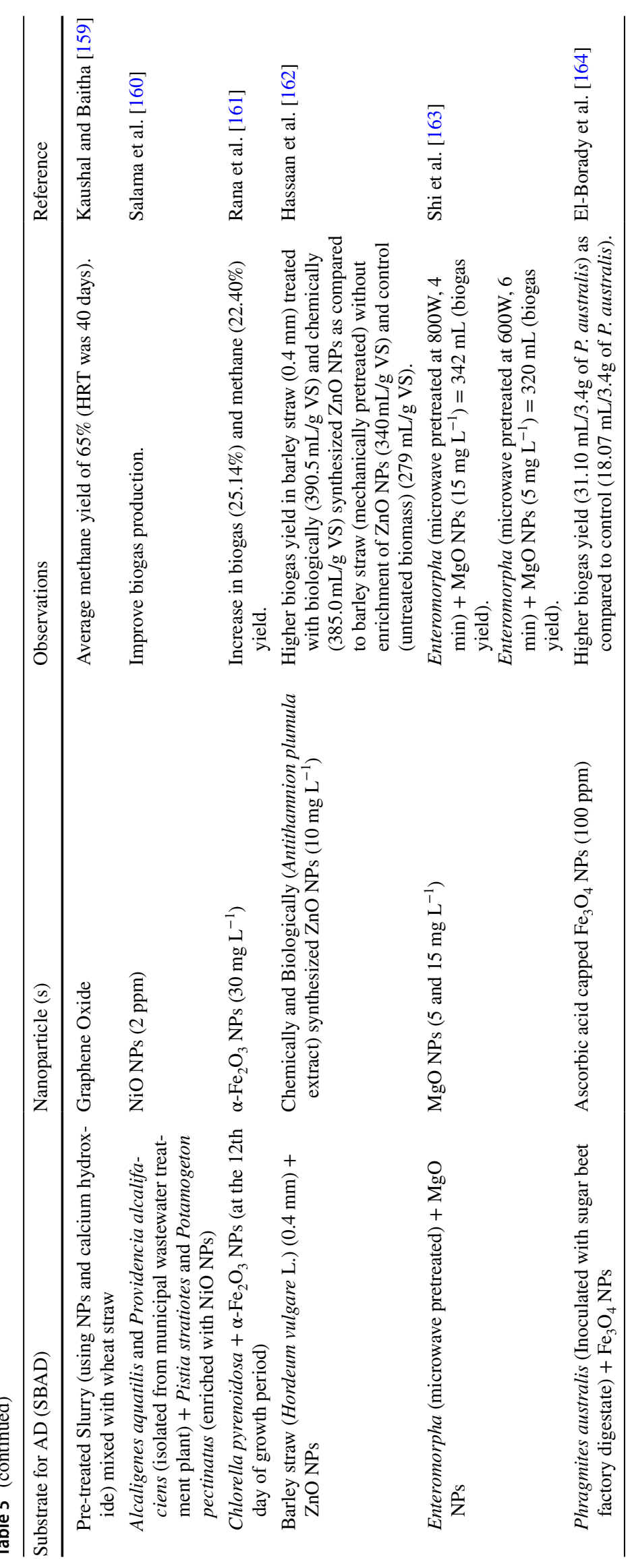


(LR) has also been described to enhance the microbial actions, and in the latest developments the LR is coupled with NP treatment for improving the biogas production [149, 150] and LCA assessment performed by Samer et al. [150] asserted that the application of LR with NPs for BSM during $\mathrm{AD}$ have minimal adverse effects on the environment as compared to control.

While reviewing the literature, we have encountered a study where nanoparticles (zinc oxide NPs, average size $\leq 40 \mathrm{~nm}$; conc. $20 \% \mathrm{w} / \mathrm{v}$ in distilled water) were supplemented with recovered BGS to investigate the effect of developed formulations on soil nutrient availability and uptake by plants [77]. BGS (biodigester feed substrate was buffalo manure) enriched with $\mathrm{ZnO}$ NPs $(1.4,2.8$, and 3.6 mg kg${ }^{-1}$ soil) at a field application rate of $270 \mathrm{~kg} \mathrm{~N} \mathrm{ha}^{-1}$ showed improved soil nitrogen content as compared to the lone application of BGS. They have found decreasing soil microbial carbon and $\mathrm{C} / \mathrm{N}$ ratio with increasing $\mathrm{ZnO} \mathrm{NP}$ concentration (amended with BGS), which is attributed to the increasing bacterial population. On reviewing the work of Aziz et al. [77] and multiple citations of peer-reviewed studies mentioned in their work, the role of NPs in increasing soil $\mathrm{N}$ and $\mathrm{P}$ for plant uptake is principally due to their influence on soil microbial population and consequently the secretion of extracellular enzymes like phosphatase (phosphorous availability) and urease (nitrogen availability) in soil. The increasing nutrient immobilization (such as $\mathrm{N}$ and P) in soil has associated risks of decreasing uptake by plants. It is also important to take note that, instead of increasing soil-N content, Aziz et al. [77] have not observed any significant increase in $\mathrm{N}$ uptake by plants with ZnO NPs + BGS treatments as compared to lone BGS, which necessitates further studies to investigate the other factors affecting shoot $\mathrm{N}$ uptake. Possibilities of biotransformation of $\mathrm{ZnO}$ NPs to zinc phosphate or phytate that can limit translocation of zinc into shoots also need to be studied further.

\subsubsection{Nanoparticles in AD of biomass}

The assessment of $\mathrm{AD}$ of biomass signifies the biogas yields coupled with the quality of recovered digestate. Trace elements are reported to have stimulatory effects on methanogens activity during the $\mathrm{AD}$ of biomass. It is interesting to compare the influence of NPs and their bulk counterparts on the $\mathrm{AD}$ during biogas production. We have reviewed the work of Abdelsalam et al. [165, 166] and Juntupally et al. [167], to get a better understanding of the subject matter in question.

Beginning with the findings of Abdelsalam et al. [165], in the case of cobalt treatments, the maximum biogas yield (BGSY) (HRT 31-35 days) was reported at $1 \mathrm{mgL}^{-1}$ CoNPs. At the same concentration and HRT, $\mathrm{CoCl}_{2}$ treatment gives lower BGSY, which was even lesser than the recorded yield at $0.5 \mathrm{mgL}^{-1}$ CoNPs. If we consider the risk of NPs toxicity at higher concentrations, the obtained results at low CoNPs concentration $\left(0.5 \mathrm{mgL}^{-1}\right)$ are comparable and better than those observed at higher concentrations of their bulk counterparts $\left(1.0 \mathrm{mgL}^{-1} \mathrm{CoCl}_{2}\right)$ (Fig. 5a). Likewise, in the case of NiNP treatment, the BGSY (HRT 26-30 days) follows the increasing trend with increase in concentration $\left(0.5 \mathrm{mgL}^{-1}\right.$ $\left.<1.0 \mathrm{mgL}^{-1}<2.0 \mathrm{mgL}^{-1}\right)$. However, the maximum BGSY (HRT 31-35) with $1.0 \mathrm{mgL}^{-1} \mathrm{NiCl}_{2}$ was lesser than the recorded yields at all the concentrations of NiNPs (Fig. 5b). Overall, the higher BGSY and lower HRT to achieve maximum yields were noticed with NiNP treatment as compared to CoNPs. Hijazi et al. [168] made similar observations with bulk counterparts (mentioned in brackets) of NiNPs $\left(\mathrm{NiCl}_{2}\right)$, CoNPs $\left(\mathrm{CoCl}_{2}\right)$, and $\mathrm{FeNPs}\left(\mathrm{FeCl}_{3}\right)$, and recorded maximum biogas production from manure treated with NiNPs $\left(1 \mathrm{gm}^{-3}\right)$ followed by CoNPs $\left(1 \mathrm{gm}^{-3}\right)$ and FeNPs $\left(1 \mathrm{gm}^{-3}\right)(\sim 7.82 \%$ and $\sim 18.87 \%$ higher as compared to CoNPs and FeNPs treatments respectively).

Abdelsalam et al. [166] performed another study on Fe-NPs (nZVI), $\mathrm{Fe}_{3} \mathrm{O}_{4}$ magnetite NPs (MNPs), and their bulk counterpart $\left(\mathrm{FeCl}_{3}\right)$. They have observed the highest BGSY in $20 \mathrm{mgL}^{-1} \mathrm{Fe}-\mathrm{NPs}$ as compared to other treatments (Fig. 5c). Similar observations were recorded for $\mathrm{Fe}_{3} \mathrm{O}_{4}$ MNPs at the same concentration (Fig. 5d). The HRT was comparatively lesser and BGSY yield was higher in the latter case $\left(\mathrm{Fe}_{3} \mathrm{O}_{4} \mathrm{MNPs}\right)$ at all the treatment concentrations. BGSY with bulk $\mathrm{Fe}\left(\mathrm{FeCl}_{3}\right)$ at $10 \mathrm{mgL}^{-1}$ was not comparable with those from NP treatments at all the investigated concentrations. Taking note of the size of synthesized NPs in both the studies, it was higher with CoNPs $(28 \pm 0.7 \mathrm{~nm})$ than NiNPs $(17 \pm 0.3 \mathrm{~nm})$ in the first study, and in the second study $\mathrm{Fe}_{3} \mathrm{O}_{4} \mathrm{MNPs}(7.0 \pm 0.2 \mathrm{~nm})$ were slightly smaller than Fe-NPs $(9.0 \pm 0.3 \mathrm{~nm})$. Thorough investigations are required to evaluate the effect of NP size on their performance during AD. Juntupally et al. [167] compared the biogas production potential of $\mathrm{Co}\left(\mathrm{CO}_{3} \mathrm{O}_{4} \mathrm{NPs}\right), \mathrm{Fe}\left(\mathrm{Fe}_{3} \mathrm{O}_{4} \mathrm{NPs}\right), \mathrm{Mo}\left(\mathrm{MoO}_{3}\right.$ $\mathrm{NPs}$ ), and $\mathrm{Ni}$ (NiO NPs) nanoparticles with their bulk counterparts, i.e., $\mathrm{CoCl}_{2}, \mathrm{Fe}_{2} \mathrm{O}_{3},\left(\mathrm{NH}_{4}\right)_{6} \mathrm{Mo}_{7} \mathrm{O}_{24} \cdot 4 \mathrm{H}_{2} \mathrm{O}$, and $\mathrm{NiCl}_{2}$ respectively. All the digesters fed with NPs showed higher biogas production over their bulk partners, with maximum values recorded for NiNPs $(21.2 \mathrm{~nm})$ followed by FeNPs $(5.6 \mathrm{~nm})$, and CoNPs (37 nm), and MoNPs (Fig. 5e).

FeNPs have been investigated in most of the studies in the area of $\mathrm{AD}$ of biomass and subsequent biogas production [154]. Fe-based additives were reported to influence microbial activity during AD [154, 166, 169]. Yang et al. [170] performed microbial diversity analysis (nZVI supplemented AD of swine manure) and found an abundance of hydrogenotrophic Methanomassiliicoccus (39.2-92.0\%). nZVI facilitates the reduction of "oxidation-reduction potential," which is reported to promote AD $[155,171]$. Ye et al. [171] also mentioned that the strong 

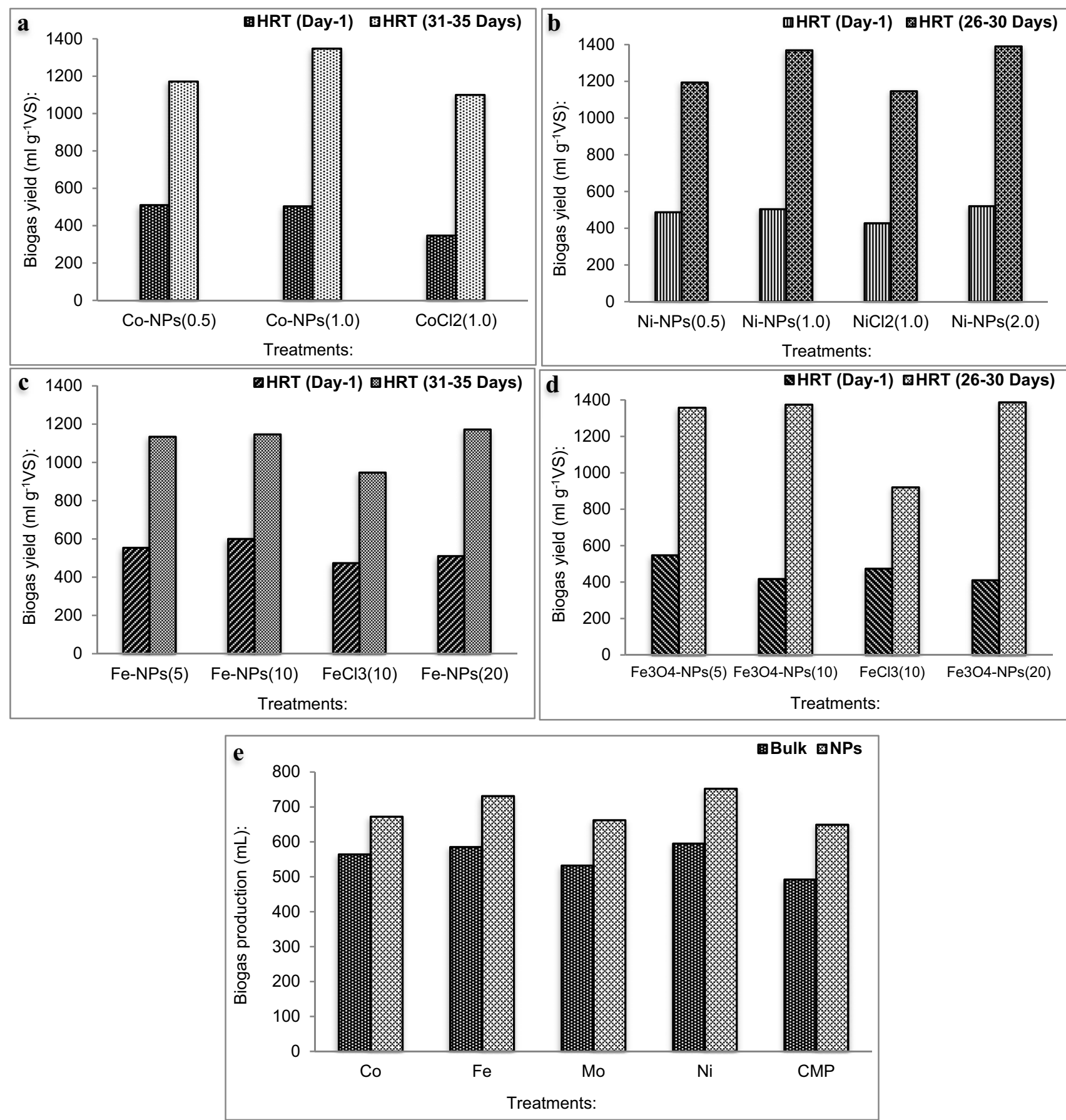

Fig. 5 Comparative analysis of the treatment of NPs and their bulk counterparts on $\mathrm{AD}$ of biomass leading to biogas production a CoNPs and $\mathrm{CoCl}_{2}$; b Ni-NPs and $\mathrm{NiCl}_{2}$ [165]; c Fe-NPs (nZVI) and $\mathrm{FeCl}_{3}$; d $\mathrm{Fe}_{3} \mathrm{O}_{4}$-NPs and $\mathrm{FeCl}_{3}$ [166]; e CO-NPs: $\mathrm{CO}_{3} \mathrm{O}_{4}$, CO-Bulk: $\mathrm{CoCl}_{2}$; Fe-NPs: $\mathrm{Fe}_{3} \mathrm{O}_{4}$, Fe-Bulk: $\mathrm{Fe}_{2} \mathrm{O}_{3}$; Mo-NPs: $\mathrm{MoO}_{3}$, Mo-Bulk:

reduction ability of nZVI facilitates pollutant removal during $\mathrm{AD}$ via direct electron transfers. NPs such as $\mathrm{Zn}$ and $\mathrm{Ni}$ are involved in multi-enzyme complexes, thus becoming one of the preferred candidates for improvements in $\mathrm{AD}$ leading to higher biogas production. $\mathrm{Ni}$ is either associated
$\left(\mathrm{NH}_{4}\right)_{6} \mathrm{Mo}_{7} \mathrm{O}_{24} \cdot 4 \mathrm{H}_{2} \mathrm{O}$; Ni-NPs: NiO, Ni-Bulk: $\mathrm{NiCl}_{2}$; CMP: Composite treatment of Bulk/NPs (Bioreactor feed include $600 \mathrm{~mL} \mathrm{CM} \mathrm{+}$ $10 \mathrm{mg}$ of NPs or bulk form or CMP of NPs/bulk form $+200 \mathrm{~mL}$ of microbial culture MMC-A) [167] (In graphs a to d, enclosed brackets in treatment categories on the $X$-axis indicates dose in $\mathrm{mgL}^{-1}$ )

with the cofactor $\mathrm{F}_{430}$ or bound to FE-S clusters, while Co is mentioned to take part in methyl group transfer [168, 172].

Amo-Duodu et al. [155] recorded higher methane yields (100\%) from NP treatments $(\mathrm{Fe}-1 \mathrm{~g}, \mathrm{Cu}-1 \mathrm{~g}, \mathrm{Ni}-2 \mathrm{~g})$ as 
compared to control (63\%) (without NP treatment, wastewater as feed substrate only). NPs such as NiNPs alone or in combination with FeNPs and CoNPs reduce the $\mathrm{H}_{2} \mathrm{~S}$ content $[151,153]$, thus yielding good-quality fuel. Not only this; in the same study, researchers mentioned the increase in TS and VS removal efficiencies in the biodigester supplemented with NiNPs at $2 \mathrm{mgL}^{-1}$ dose. Similar observations were reported by Abdelwahab et al. [151] with FeNPs (at 15 $\mathrm{mgL}^{-1}$ ). $\mathrm{pH}$ was also recorded at the ideal range for optimal activity of microbes during the digestion process in both the studies at selective treatments. Juntupally et al. [173] found higher methane production from $\mathrm{AD}$ of pre-treated horse manure (HM) (dilute acid thermal pretreatment) added with $40 \mathrm{mgL}^{-1} \mathrm{Fe}_{3} \mathrm{O}_{4} \mathrm{NPs}$ as an accelerant, though in untreated $\mathrm{HM}$, they have found maximum yields with $60 \mathrm{mgL}^{-1} \mathrm{Fe}_{3} \mathrm{O}_{4}$ NPs. Overall, using the strategy of biomass pretreatment, the dose of NPs can be reduced as an accelerant during AD, with higher methane yields and reduced HRT. The addition of nickel NPs in biogas feed (CM) can improve the fertilizer potential of recovered effluents [151]. BGS (feed substrate buffalo manure) (field application at $270 \mathrm{~kg} \mathrm{~N} \mathrm{ha}^{-1}$ ) enriched with different doses of ZnO NPs (average size $\leq 40$ $\mathrm{nm}$; conc. $20 \% \mathrm{w} / \mathrm{v}$ in distilled water) $(1.4,2.8$, and $3.6 \mathrm{mg}$ $\mathrm{kg}^{-1}$ soil) improves soil nitrogen content [77]. The application of nanofertilizers can reduce nutrient leaching loss, thus promoting the efficiency of nutrient use [174].

Not only the elemental nanoparticles; other particles/ materials of nano-dimensions have also been reported to have potential application in biomass degradation. Lignin degradation is one of the challenging tasks during biofuel production from the lignocellulosic feedstocks. Yang et al. [175] in an innovative approach reported 10\% higher lignin breakdown (initial concentration of $50 \mathrm{mgL}^{-1}$ ) using nitrogen nanobubble water as compared to the control (during ACD with activated water sludge). An increase in activity of methanogenic bacteria during $\mathrm{ACD}$ is attributed to higher methane production as well. They have anticipated the role of hydroxyl ions generated by nitrogen nanobubble water behind such observations.

\subsubsection{Nanoparticle-microbe interaction}

As reviewed by Abdelsalam and Samer [172], the interaction of NPs with the biological systems can involve either direct uptake (via ATP dependent system; depends upon size and speciation of the NPs) or complexation with the dissolved organic matter (DOM) (on cell membrane DOM-NP complex binds with the MBRs). NP uptake by methanogens involved "metalloenzyme, electron transfer, and reduction pathways" during methane production [172].

Kumar et al. [176] reviewed the applications of conductive NPs (abbreviated as CNPs) to improve the efficiency of $\mathrm{AD}$ leading to higher methane production. The relatively low efficiency of mediated interspecies electron transfer (MIET) as a consequence of diffusion limitations with $\mathrm{H}_{2}$ as an electron carrier during $\mathrm{AD}$ limits the process of methanogenesis. In contrary to this, direct interspecies electron transfer (DIET) enables direct interaction (cell-to-cell electrons transport) between the methanogens and bacteria during $\mathrm{AD}$ and facilitates metabolic conditions favored higher rates of methane production.

Cruz Viggi et al. [146] via theoretical valuations cited that DIET permits higher electron transfer rates among syntrophic bacteria as compared to IHT (Interspecies $\mathrm{H}_{2}$ transfer)/MIET. Basically, in IHT, the hydrogen acts as an electron carrier and mediates the transfer of electrons to the methanogens from secondary fermenting bacteria (SPB). Hence, the involvement of SPB in generating hydrogen as reducing equivalents requires energy and is thermodynamically not favored under standard conditions. Instead in DIET, the electron transfer is accomplished either via conductive pili or membrane-bounded cytochromes (c-type) without the requirement of such electron carriers; thus, DIET is more feasible in terms of energy requirements [137].

CNPs have been reported to play an important role in such microbial interactions for electron transfer during AD [176]. Zhang et al. [177] also investigated the role of magnetite-NP treatment favoring DIET and FE-S precipitation leading to improved methane yields. Through microbial community analysis, they have also predicted the role of magnetite-NPs in increasing methanogenesis over acetogenesis. For methane production, Yang et al. [170] found the addition of nZVI more beneficial during the methanogenic stage as compared to the acidogenic stage. Farghali et al. [178] reported enhanced methanogenic activity during $\mathrm{AD}$ of $\mathrm{CM}$ as a result of $\mathrm{TiO}_{2}-\mathrm{NP}$-assisted extracellular electron transfer (EET), and Ti-S clusters also brings reductions in $\mathrm{H}_{2} \mathrm{~S}$ levels. Wang et al. [179] characterize the Tungstenbased nanomaterials to establish DIET for improving AD of biomass. Attributes such as stable chemical properties during $\mathrm{AD}$, zero band gap (results in higher electrical conductivity, potential to act as electron carriers during DIET), and co-existing of syntrophic bacteria and methanogens in biodigester as revealed from pyrosequencing studies yield conceivable pieces of evidence in support of tungsten-based NPs as one of the potential accelerants of AD. Van Steendam et al. [180] for improving AD via DIET recommends the development of appropriate characterization methods.

$\mathrm{Bi}$ et al. [139] found the increasing activity of hydrogenotrophic (HGM) and acetoclastic methanogens (ACM) during solid $\mathrm{AD}$ of chicken manure supplemented with $\mathrm{Ni}^{2+}$ and $\mathrm{Fe}^{2+}$ treatments. Yang et al. [141] with ZVI powder supplementation $\left(5 \mathrm{gL}^{-1}\right)$ found a higher relative abundance of Methanoculleus species (39.9\%) as compared to the control experiment (34.6\%) and these species belongs to hydrogenotrophic methanogens reported to thrive under high ammonia conditions (HACs) 
during $\mathrm{AD}$. ACM has higher substrate utilization potential; hence, a possibility of sustaining higher ACM activity during HACs through ZVI enrichment also existed that favors fixation of $\mathrm{CO}_{2}$ into methane and sustained performance of anaerobes could also be attributed to the adaptive biochemical plasticity of these microbes under such stressed conditions [141]. The researchers also recovered $\sim 66.0 \%$ of ZVI powder from the bioreactor after the experiment.

Kato et al. [181] observed that supplementing methanogenic microbes with hematite or magnetite nanoparticles (10-50-nm size) hasten methanogenesis (in terms of production rate and lag time) from ethanol and acetate. A schematic representation highlighting the role of Fe-NPs in $\mathrm{AD}$ of biomass is included in Fig. 6. The different routes leading to methane production has been reviewed keeping in view of both IHT and DIET process. $\mathrm{Fe}^{2+}$ ions through $\mathrm{Fe}-\mathrm{S}$ precipitation also pave the route for $\mathrm{H}_{2} \mathrm{~S}$ mitigation. Methylotrophic, hydrogenotrophic, and acetoclastic are the three pathways of methane production during $\mathrm{AD}$, and enzymes catalyzed in each step have specific metal requirements [182]. Hence, it is proposed to develop nano-elemental formulations to fulfill such requirements of participating enzymes in all three production pathways and optimize the methanogenic activity for improved methane production.

NGS allows analysis of microbial diversity and dynamics during AD. Such investigations are vital to screen the most efficient microbes during the AD utilizing different biomass feedstocks and accelerants including trace metals and nanoparticles. In one such study, Eduok et al. [183] found abundance of Methanosarcina in the digesters spiked (at $~ 0.67 \mathrm{~mL}^{-1} \mathrm{~L} \mathrm{day}^{-1}$ for 315 days) with the mixture of Ag NPs $(20 \mathrm{~nm})\left(0.01 \mathrm{mgL}^{-1}\right), \mathrm{ZnO}$ NPs $(20 \mathrm{~nm})\left(0.12 \mathrm{mgL}^{-1}\right)$, and $\mathrm{TiO}_{2}(21 \mathrm{~nm})\left(0.08 \mathrm{mgL}^{-1}\right)$. As per the previous reports, this archaeal genus possesses remarkable properties of multi-substrate utilization for biogas production, adaptations to NPs presence [183], and most important the capacity to catalyze all the major pathways leading to methane production during $\mathrm{AD}$ (acetoclastic, hydrogenotrophic, methylotrophic, and methyl reduction pathways) [183, 184].

Zhang et al. [87] reported nitrogen removal applying nanoparticle treatment, in which ZnO NPs at low concentrations (up to $5 \mathrm{mgL}^{-1}$ ) increase the activity of anaerobic-oxidizing bacteria (ANOB) and ammonia-oxidizing bacteria (AAOB)

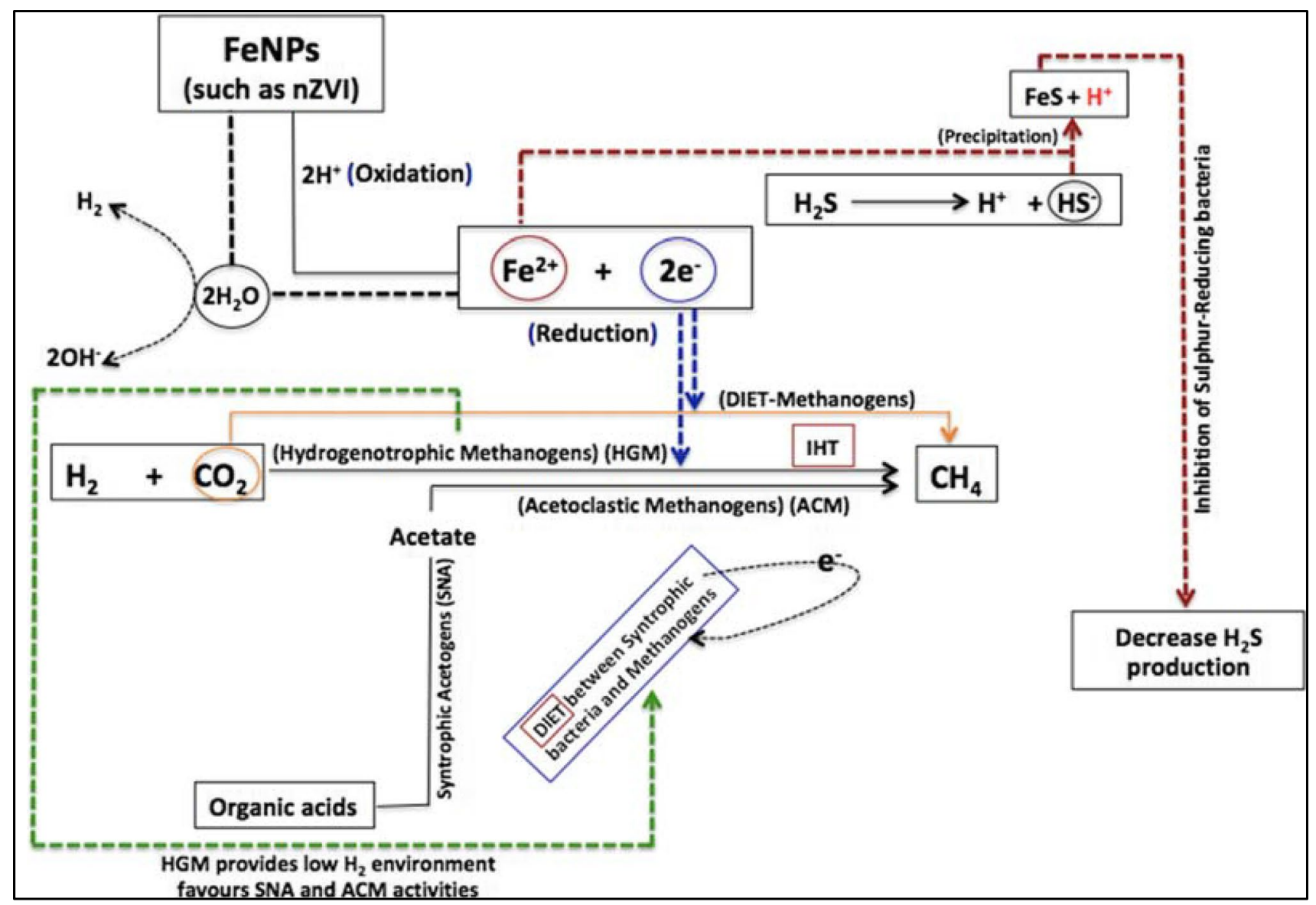

Fig. 6 Interaction between Fe-NPs and microbes during AD of organic substrates ( source: conceptualized from the multiple authors referred in the manuscript) 
to remove nitrogen from the sludge (Fig. 7). The activity of these bacteria inhibits nitrate formation through the suppression of nitrogen-oxidizing bacteria (NOB) activity. They have noticed the increase in microbial diversity at low concentrations of $\mathrm{ZnO}$ (Fig. 8). The OTU count and Shannon Index (SI) were highest at $\mathrm{ZnO} \mathrm{NPs} 1 \mathrm{mgL}^{-1}$ (OTU=998,

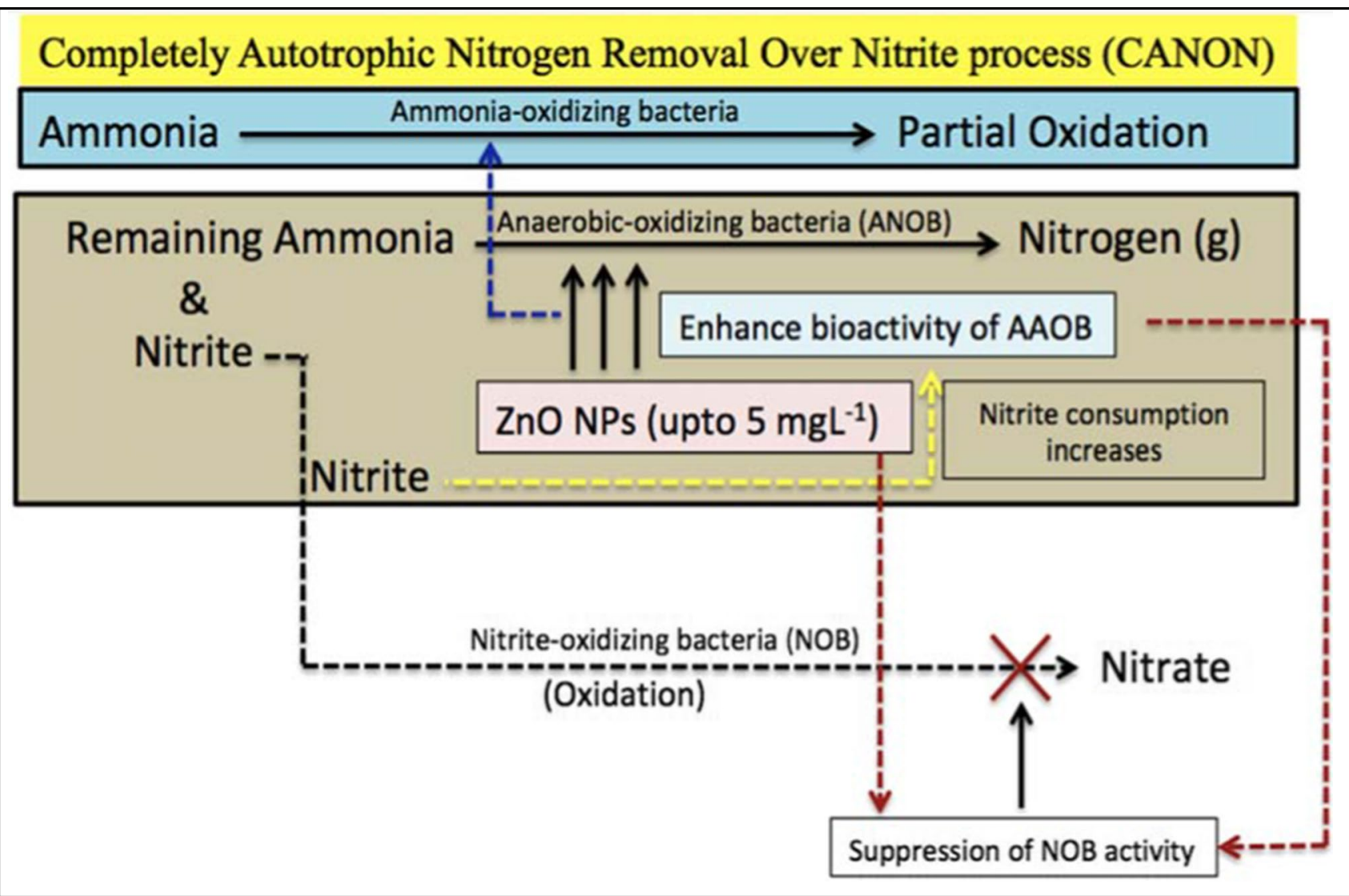

Fig. 7 Role of ZnO NPs in the removal of nitrogen from sludge during the CANON process (Conceptualized from [87])

Fig. 8 Effect of $\mathrm{ZnO} \mathrm{NP}$ concentration on the relative abundance of bacteria participating in $\mathrm{AD}$ [87] $(\mathrm{C}=$ control experiment without $\mathrm{ZnO} \mathrm{NP}$ addition; T1, T2, T3, and T4 are treatments with $\mathrm{ZnO} \mathrm{NPs}$ concentrations $1,5,10$, and $20 \mathrm{mgL}^{-1}$ respectively, and $\mathrm{T} 5$ represents treatment in which no further addition of $\mathrm{ZnO}$ NPs done; B1: ammonia-oxidizing bacteria; B2: anaerobic-oxidizing bacteria; and B3: nitriteoxidizing bacteria)

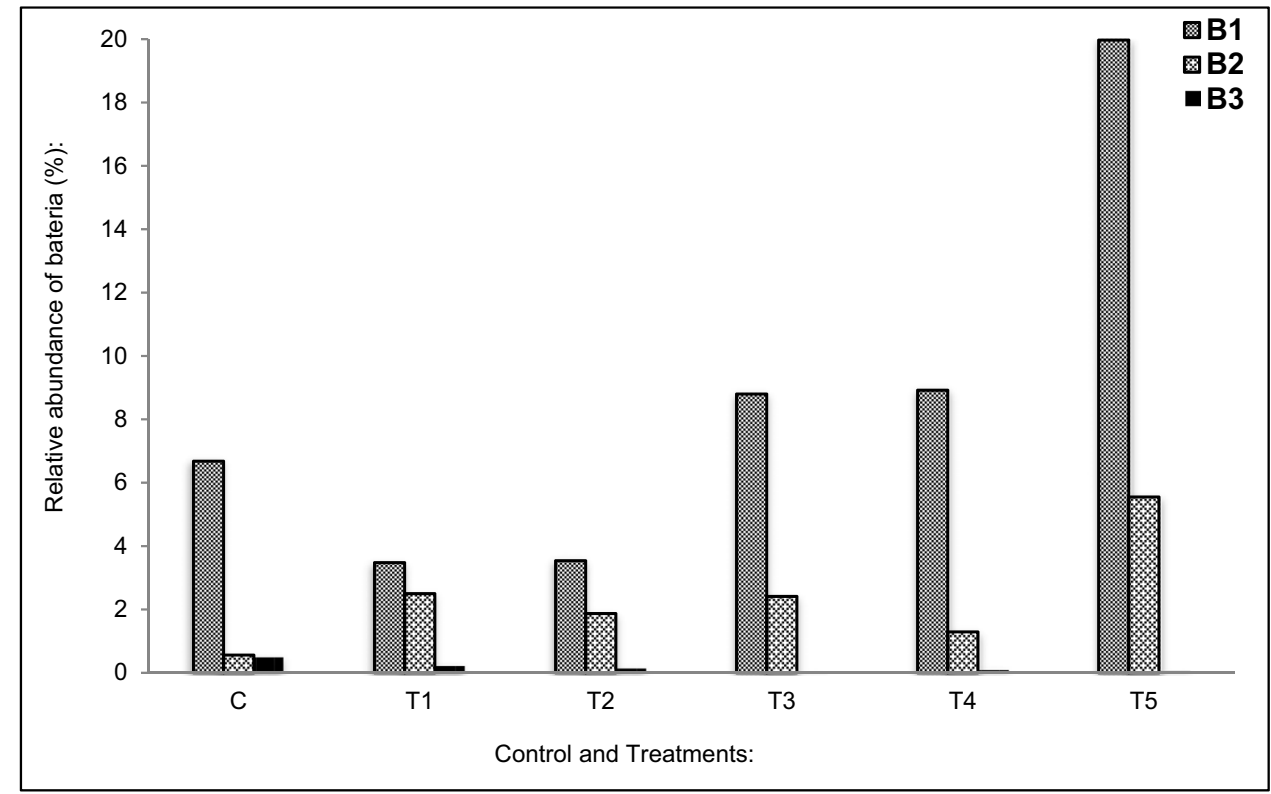


$\mathrm{SI}=4.39$ ) followed by $5 \mathrm{mg} \mathrm{L}^{-1}(\mathrm{OTU}=958, \mathrm{SI}=4.34)$. They have also observed the improvements in nitrogen removal at these treatment doses. Lower concentrations of nanoparticles ( $\mathrm{Fe}, \mathrm{Cu}$, and Ni NPs) favor nutrient supply for microbially inspired AD [155]. He et al. [185] in their investigation found higher sensitivity of microbes towards $\mathrm{ZnO}$ NPs at genus and phylum levels as compared to class level. Thus, nanoparticle treatment significantly alters the microbial community structure during AD of biogas feed substrates [86].

As stated above, nanoparticles play a significant role in the AD of biomass; this could serve as an opportunity to generate nutrient-rich digestate in addition to improved bioenergy efficiency. To achieve this objective, studies are warranted to advance our understanding of how nanoparticles interact with the microbes during AD, and the role of NPs to elicit the metabolic pathways in microbes followed by the screening and characterization of bioactive molecules was thereby produced. To further strengthen this, in our point of view, studies exploring the microbial diversity and dynamics in varied biomass feedstock and anaerobic digestates are vital, in which NGS could have an important contribution.

\subsubsection{Nanoparticles co-aggregation}

ZnO NPs are one of the highly used engineered nanomaterials [187]. AD systems encountered toxicity at higher doses of $\mathrm{ZnO}$ NPs. Tong et al. [188] in a phototoxicity analysis, reported $\sim 40 \%$ disruption of the cellular membrane (CMM) in $E$. coli at $25 \mathrm{mgL}^{-1}$ concentration of $\mathrm{ZnO} \mathrm{NPs}$, and such damaging effects were not visible at a lower dose of $\mathrm{ZnO}$ NPs $\left(1 \mathrm{mgL}^{-1}\right)$. Ye et al. [189] reported denitrification suppression by $\mathrm{ZnO}$ NPs in a dose-dependent manner (1, 25 , and $50 \mathrm{mgL}^{-1}$ ) owning to a decrease in total nitrogen removal rates and $\mathrm{N}_{2} \mathrm{O}$ emissions. They observed higher sensitivity of denitrification as compared to the nitrification process to $\mathrm{ZnO}$ nanotoxicity. However, to extenuate the effect of $\mathrm{ZnO}$ nanotoxicity (reported to be due to free $\mathrm{Zn}^{2+}$ and generation of reactive oxygen species like $\mathrm{H}_{2} \mathrm{O}_{2}$ and .OH) on anaerobes during AD, Zhang et al. [190] performed a combined toxicity assessment of $\mathrm{ZnO}$ and $\mathrm{TiO}_{2}$ NPs and observed decrease in $\mathrm{Zn}^{2+}$. The previous studies also found a decrease in $\mathrm{ZnO}$ NP toxicity as a result of $\mathrm{Zn}^{2+}$ absorption in presence of $\mathrm{TiO}_{2}$ NPs, as cited by [190].

Despite phototoxicity of $\mathrm{TiO}_{2} \mathrm{NPs}$ at $10 \mathrm{mg} \mathrm{L}^{-1}$ to $E$. coli ( $65 \%$ CMMs damage), their treatment in combination with $\mathrm{ZnO} \mathrm{NPs}\left(\mathrm{TiO}_{2} \mathrm{NPs}_{10} \mathrm{mgL}^{-1}+\mathrm{ZnO} \mathrm{NPs}_{1} \mathrm{mgL}^{-1}\right.$ ) reported no toxicity, which appears to be eliminated by the $\mathrm{ZnO}$ NPs ( $\mathrm{ZnO}$ NPs avoids close surface interaction of $\mathrm{TiO}_{2}$ NPs/aggregates with bacterial CMMs) [188]. In another interesting observation, the authors reported that unlike in the case of phototoxicity, the $\mathrm{TiO}_{2}$ and $\mathrm{ZnO}$ NP combina-

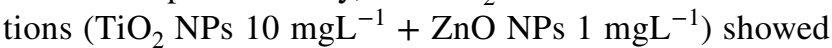

an additive effect in generating ROS. Now the question is despite generating higher ROS during combined treatment as a consequence of additive effect, how does this combination minimize the toxicity damage? They have proposed some possibilities behind such observations. One of these is, in case of combined treatment with concentrations, i.e., $\mathrm{TiO}_{2}$ NPs $10 \mathrm{mgL}^{-1}+\mathrm{ZnO}$ NPs $1 \mathrm{mgL}^{-1}$, the formation of $\mathrm{ZnO}-\mathrm{TiO}_{2}$ aggregates established diminished contact with the CMMs of bacteria; thus, generated ROS in the majority did not make contact with bacterial CMMs, despite additive effects. Moving ahead, the authors also found that the combined treatment effect (in terms of phototoxicity) of $\mathrm{TiO}_{2}$ NPs $10 \mathrm{mgL}^{-1}+\mathrm{ZnO}$ NPs $25 \mathrm{mgL}^{-1}$ was comparable with that of their individual treatment dose (i.e., $\mathrm{TiO}_{2} \mathrm{NPs}_{\text {at }} 10$ $\mathrm{mgL}^{-1}$ and $\mathrm{ZnO}$ NPs at $25 \mathrm{mgL}^{-1}$ ); for this, the authors have mentioned that the larger $\mathrm{ZnO}$ NPs blocked the contact of several $\mathrm{TiO}_{2}$ NPs with bacterial CMMs.

Further studies are duly recommended to examine the role of $\mathrm{ZnO} \mathrm{NP}$ interaction with different components of AD (such as IET, syntrophic bacteria and methanogen activity, $\mathrm{H}_{2} \mathrm{~S}$ mitigation) for improved levels of produced methane coupled with the nutrient profile of recovered digestate (solid and liquid fractions). Besides this, integrated approaches must be explored to reduce the possibilities of ZnO NP toxicity interfering with AD of biogas feedstocks (precisely while using the wastewater sludge, or similar waste of anthropogenic origin). As stated earlier, the $\mathrm{ZnO}$ NP toxicity is mainly attributed to their dissolution and availability as free $\mathrm{Zn}^{2+}$ in the system [187, 188, 190, 191]; thus, investigating the suitable adsorbents or trace element/ NPs co-aggregates will provide an opportunity to recover zinc in the digestate, which can be further utilized as a potential fertilizer in the zinc-deficient soil.

\subsubsection{Environmental impacts}

Nanotechnology-driven AD of biomass reported to enhance biogas/methane production; however, utilization of spent BGS must be investigated for toxicity analysis (on plants, beneficial microbes, etc.) before using as a fertilizer source for agriculture applications due to the associated risk of NP accumulation [78]. Hijazi et al. [192] performed the life cycle assessment (LCA) study to estimate the environmental impact of NP introduction (CoNPs: $1 \mathrm{~g} \mathrm{~m}^{-3}$, NiNPs: 2 $\mathrm{g} \mathrm{m}^{-3}$, FeNPs: $15 \mathrm{~g} \mathrm{~m}^{-3}, \mathrm{Fe}_{3} \mathrm{O}_{4}$ NPs: $20 \mathrm{~g} \mathrm{~m}^{-3}$, and without NP treatment served as a control) during AD of manure for biogas production. For the analyzed six parameters (in reference to the electricity production by NPs treated and control biomass), CoNP treatment was best in terms of lowest: GHG emission, acidification, eutrophication, and human toxicity potential. NiNP treatment has the lowest risk of resource and ozone layer depletion. The representative view highlighting trends in the variation of environmental 
indicators associated with the electricity generation from the NPs treated biomass and control experiment is shown in Table 6 . It has been clearly observed that the untreated biomass (control) presented with the highest risk with reference to all the investigated environmental indicators. Considering an overall environmental impact, Hijazi et al. [192] recommended CoNPs for biomass treatment (AD) and electricity generation through obtained biogas.

Nguyen et al. [193] performed toxicity analysis of metallic nanoparticles on $E$. coli before and after AD and observed higher toxicity in samples before AD. Garcia et al. [194] observed $100 \%$ and 33-50\% toxicity of $\mathrm{CeO}_{2} \mathrm{NPs}$ and Ag NPs on biogas production respectively. However, there was no or negligible toxicity of Au NPs, and $\mathrm{TiO}_{2} \mathrm{NPs}$ were reported towards oxidative heterotrophic organisms, ammonia-oxidizing bacteria, and anaerobic biomass. Dispersion of $\mathrm{ZnO}$ NPs caused $99 \%$ E. coli cell death at $100 \mathrm{mgL}^{-1}$ [193]. $\mathrm{CeO}_{2} \mathrm{NPs}$ at $10 \mathrm{mgL}^{-1}$ showed a positive effect on the $E$. coli population [193]. Zhang et al. [186] in a study on AD of sludge using NPs (carbon NPs, ZnO NPs, CuO NPs, and $\mathrm{Al}_{2} \mathrm{O}_{3} \mathrm{NPs}$ ) reported an abundance of mobile genetic elements in Phylum Proteobacteria followed by Firmicutes. The nZVI $(55 \pm 11 \mathrm{~nm})$ at $30 \mathrm{mM}$ concentration was reported to inhibit methanogenesis as a result of disruption of the microbial cell membrane and rapid $\mathrm{H}_{2}$ production [195]. Ma et al. [196] found an nZVI concentration of $160 \mathrm{mgL}^{-1}$ suitable for reducing antibiotic resistance genes during $\mathrm{AD}$ of $\mathrm{CM}$ and also reported an increase in methane yield (6.43\%). As per Zheng et al. [197], the variations in bioavailable fractions of heavy metals (like $\mathrm{Zn}, \mathrm{Ni}$ ) during $\mathrm{AD}$ (swine manure was feed substrate) depend upon three important digestion variables, i.e., concentration of ammoniacal nitrogen $<$ methane content in daily biogas yield $<\mathrm{pH}$ (arranged as per the order of importance reported in the study).

Hassanein et al. [198] utilized the recovered effluent from the digester as a fertilizer source for Lactuca sativa. Despite

Table 6 Trends in the variation of environmental indicators associated with the electricity generation (bioenergy) from the NPs treated biomass and control experiment [192]

\begin{tabular}{llllll}
\hline $\begin{array}{l}\text { Environmental indi- } \\
\text { cators }\end{array}$ & CoNPs & NiNPs & $\mathrm{FeNPs}$ & $\mathrm{Fe}_{3} \mathrm{O}_{4} \mathrm{NPs}$ & Control \\
\hline GHGs emission & 1 & 2 & 4 & 3 & 5 \\
Acidification & 1 & 4 & 3 & 2 & 5 \\
Eutrophication & 1 & 3 & 2 & 4 & 5 \\
$\quad \begin{array}{l}\text { Resource depletion } \\
\quad 3\end{array}$ & 1 & 4 & 2 & 5 \\
$\quad \begin{array}{l}\text { Ozone layer deple- } \\
\text { tion }\end{array}$ & 2 & 1 & 4 & 3 & 5 \\
$\begin{array}{l}\text { Human toxicity } \\
\text { potential }\end{array}$ & 1 & 3 & 4 & 2 & 5 \\
\hline
\end{tabular}

*Numbers from 1 to 5 indicate an increasing trend of the environmental indicators impact, i.e., $1<2<3<4<5$. approximately similar levels of $\mathrm{N}, \mathrm{P}, \mathrm{K}, \mathrm{Zn}, \mathrm{Mn}, \mathrm{Cu}$, and $\mathrm{Na}$ in both the digester effluents, i.e., NP fed (NPD) (continuous digester containing NP mixture, i.e., FeNPs $1000 \mathrm{mgL}^{-1}$, NiNPs $120 \mathrm{mgL}^{-1}$, and CoNPs $54 \mathrm{mgL}^{-1}$ fed twice on days 84 and 202) and control (CND) (biogas feedstock was cow dairy manure in both the digesters), the $L$. sativa fertilized with NPD effluent showed higher amount of these nutrients in its biomass as compared to those fertilized with CND effluent (both the digester effluents were diluted to 1:13.8 using deionized water $(7.6 \mathrm{~L})$ divided into five loadings over the growth period of 57 days). This could be attributed to the increasing nutrient uptake and translocation efficiency as a consequence of NP treatment. The recorded values of $\mathrm{Fe}, \mathrm{Ni}$, and $\mathrm{Co}$ in L. sativa were below the reported toxic limits. However, further investigations are much indeed in the area of NP introduction to the various levels of the food chain and in-depth assessment of their toxicity leading to the health and environmental implications. The authors have recommended such studies as well.

The non-biodegradable nature of metallic particles possesses a risk of toxicity [147] in the concerned environment. In the investigation of Luna-delRisco et al. [147], it has been observed that one of the reasons behind the toxicity of such particles is attributed to their aqueous solubility (AQS). They have reported poor AQS of $\mathrm{CuO}$ NPs, $\mathrm{ZnO}$ NPs, and their bulk counterparts, though it was noticed higher AQS of $\mathrm{CuO}$ NPs than their bulk counterpart that can partially be contributed to the higher toxicity potentials. The order of toxicity to anaerobic bacteria was reported in the following order: $\mathrm{CuO}$ NPs $(\sim 30 \mathrm{~nm})>\mathrm{ZnO}$ NPs $(\sim 50-70 \mathrm{~nm})>\mathrm{ZnO}$ Bulk> CuO Bulk. Taking account of recovery of $\mathrm{Cu}^{2+}$ ions (at higher $\mathrm{CuO} \mathrm{NP}$ treatment doses, i.e., $120-480 \mathrm{mgL}^{-1}$ ) in liquid fraction of digestates, the proportion was highest at $\mathrm{CuO} \mathrm{NP}$ concentration of $240 \mathrm{mgL}^{-1}(\sim 14.5 \%)$ followed by $480 \mathrm{mgL}^{-1}(\sim 9.94 \%)$ and $120 \mathrm{mgL}^{-1}(\sim 6.58 \%)$. Hence, the concentrations and types of NPs can significantly affect the microbial diversity during AD. As compared to control (without the addition of NPs), Hui and Kui [199] observed a higher sludge humification index (20.7-49.6\%) during the process of vermicomposting in treatments with $\mathrm{ZnO}$ and $\mathrm{TiO}_{2}$ NPs, which is attributed to the rich microbial diversity supported by NPs, as evidenced from the presence of organic acids, aromatic compounds, and polysaccharides in the final vermicompost product. The higher nanoparticle concentrations will also affect the process of AD of sludge (methanation, hydrolysis, acidification) as observed by $\mathrm{Mu}$ et al. [200] in the case of increasing ZnO NP dose. They have also noticed the inhibition of enzymatic activities at such doses. Furthermore, to explore this area in greater detail, studies related to the environmental exposure of nanoparticles and their toxicity analysis are important. Nanotoxicity studies (phytotoxicity, cytotoxicity, and genotoxicity) must be accomplished with thorough investigations on the 
impact of nanoparticle types along with their shape, size, and concentration.

\subsection{Nutrient recovery from BGS}

Direct applications of BGS in agriculture fields have certain concerns regarding its physical (presence of debris such as plastics, glass, etc.), chemical ( $\mathrm{pH}$, nutrient composition, presence of heavy metals), and biological qualities (presence of pathogens) [13]. This will consequently entail some preconditioning or value additions. On surveying literature, different methods of nitrogen removal/recovery from the liquid fraction of BGS such as Anammox, membrane separation, absorption, and struvite crystallization, were encountered [13]. Solid digestate can be exploited directly or subjected to composting or drying and used as a rich source of phosphorous [13]. On the other hand, the liquid fraction of the digestate (LFD) is of great interest for researchers as it provides $\mathrm{N}$ and $\mathrm{K}$. The difference between nitrogen removal (converting ammonium into nitrogen gas) and recovery (ammonium fixation to be further utilized as $\mathrm{N}$ source in agriculture fields) from the LFD is imperative. Menkveld and Broeders [201] described the Nijhuis Ammonium Recovery System (NAR) based on chemical stripping and asserted removal efficiency of ammonia between 85 and $90 \%$ from AD manure or organic wastewaters. Schematic representation of the NAR system has been mentioned in Fig. 9a. Here strategically, $\mathrm{CO}_{2}$ stripping has been done through the introduction of fresh air; consequently, the $\mathrm{pH}$ increases and the requirement of $\mathrm{NaOH}$ decreases. Higher $\mathrm{pH}$ in ammonia stripper increase ammonia volatilization and ammonium phosphate recovery can reach $25-40 \%$ under optimized conditions, as stated.

Nitrogen recovery using chemical stripping is an energyextensive process with high temperature and chemical treatments $\left(\mathrm{NaOH}\right.$ and $\left.\mathrm{H}_{2} \mathrm{SO}_{4}\right)$ [202]. Battista et al. [202] in an innovative step performed recovery of nitrogen as ammonium sulfate ( $2 \mathrm{M}$, yield under optimized process) from ADDC using solar energy-driven lab-scale greenhouse (Fig. 9b). The recovered solid digestate was evaluated as P-source on growth in maize and results were comparable to commercial triple superphosphate fertilizer under observed greenhouse pot experiments. Xu et al. [134] used vermiculite (P content $0.1 \%$ ) as an accelerant during ACD of Aloe peel waste and dairy manure for biogas production and found maximum $\mathrm{N}(\%), \mathrm{K}(\%)$, and total nutrient content (TNC) $(\%)$ in digestate with vermiculite $(0.3 \%)$ (DVM) as compared to control and other treatments (digestate with $0.1 \% / 0.6 \% / 0.9 \%$ vermiculite). The accelerant property of vermiculite favoring biomass decomposition could be attributed to the release of trace elements such as $\mathrm{Fe}^{3+}, \mathrm{Ca}^{2+}$, $\mathrm{Mg}^{2+}, \mathrm{Zn}^{2+}$ and $\mathrm{Al}^{3+}$, as cited by them. Compared to control, DVM-0.3\% have $~ 12.57 \%, \sim 15.07, \sim 25.71$, and $\sim 15.42 \%$ higher N, P, K, and TNC respectively. Ehmann et al. [203] also recovered $\mathrm{P}$ from anaerobic digestates. Gienau et al. [204] in an optimized membrane treatment process (centrifugation, ultrafiltration, and reverse osmosis) recovered nutrient-rich solid (total nitrogen: 8.2-12.0 kg/t, $\mathrm{P}_{2} \mathrm{O}_{5}$ : $5.6-10.4 \mathrm{~kg} / \mathrm{t})$ digestate and LFD $\left(\mathrm{NH}_{4}{ }^{+}-\mathrm{N}: 2.9-5.6 \mathrm{~kg} / \mathrm{t}\right.$, $\left.\mathrm{K}^{+}: 6.2-9.2 \mathrm{~kg} / \mathrm{t}\right)$.

He et al. [205] reported optimum $\mathrm{pH}$, removal temperature, and pressure of $13.04,35^{\circ} \mathrm{C}$, and $15 \mathrm{kPa}$ respectively for the removal of ammonia-nitrogen (AMN) through vacuum distillation. They have concluded that under the conditions of high $\mathrm{pH}$, vacuum distillation of BGS can yield higher removal rates of AMN. In a "vacuum membrane distillation" (VMD) process, under alkaline $\mathrm{pH}$ (10) of bioslurry, He et al. [206] recorded over $90 \%$ conversion of TAN into free ammonia. They also observed that the alkaline treatment during the VMD process substantially reduces the BGS phytotoxicity. In both studies, recovered ammonia can act as a potential $\mathrm{CO}_{2}$ absorbent. In another study, $\mathrm{He}$ et al. [207] recovered free ammonia from BGS using the VMD process, and the recovered ammonia showed better performance as a $\mathrm{CO}_{2}$ absorbent in upgrading biogas as compared to the other tested absorbents. Chen et al. [208] used vacuum-assisted gas-permeable membrane (V-GPM) for ammonia recovery from LFD and reported over $80 \%$ removal (In $6 \mathrm{~h}, 70^{\circ} \mathrm{C}$ temperature, and $30 \mathrm{kPa}$ pressure). The technique was reported to have negative GHG emissions [209]. García-González et al. [210] recovered ammonia from digestate (obtained from ACD of pig manure and agro-food waste) using gas-permeable membranes with $71 \%$ efficiency of $\mathrm{N}$ recovery. The carbonaceous materials are retained with the digestate using this technology as cited by García-González et al. [210]. The ammonium ions in LFD can also be transformed to the gaseous phases such as hydrogen, ammonia, and $\mathrm{N}_{2} \mathrm{O}$ through hydrolysis, stripping, and Nitrification-denitrification process respectively, for further utilization as an energy source [211]. For recovery of ammonia and biogas (up-gradation) from the wastewater digestates of high strength, a hydrophobic membrane-based ammonia recovery system link coupled with an electromethanogenic microbial electrolysis cell has been reported [212].

Taking account of the adsorption process for nutrient removal, biochar has been explored as one of the low-cost adsorbing materials with promising outcomes [213]. Heterogeneity in biochar surface facilitates different adsorption mechanisms [214]. Adsorption mechanisms for nutrient removal from BGS using iron modified biochars (pyrolysis of corn straw at $690^{\circ} \mathrm{C}$ temperature) include flocculation, electrostatic attraction, functional group reaction, ion exchange in case of nitrogen, flocculation, co-precipitation, ligand exchange, and surface complexation in the case of phosphorous [213]. Maximum adsorption values recorded using iron-modified biochars were 11.68 and $26.14 \mathrm{mg} \mathrm{g}^{-1}$ for nitrogen and phosphorous respectively [213]. Kubar 

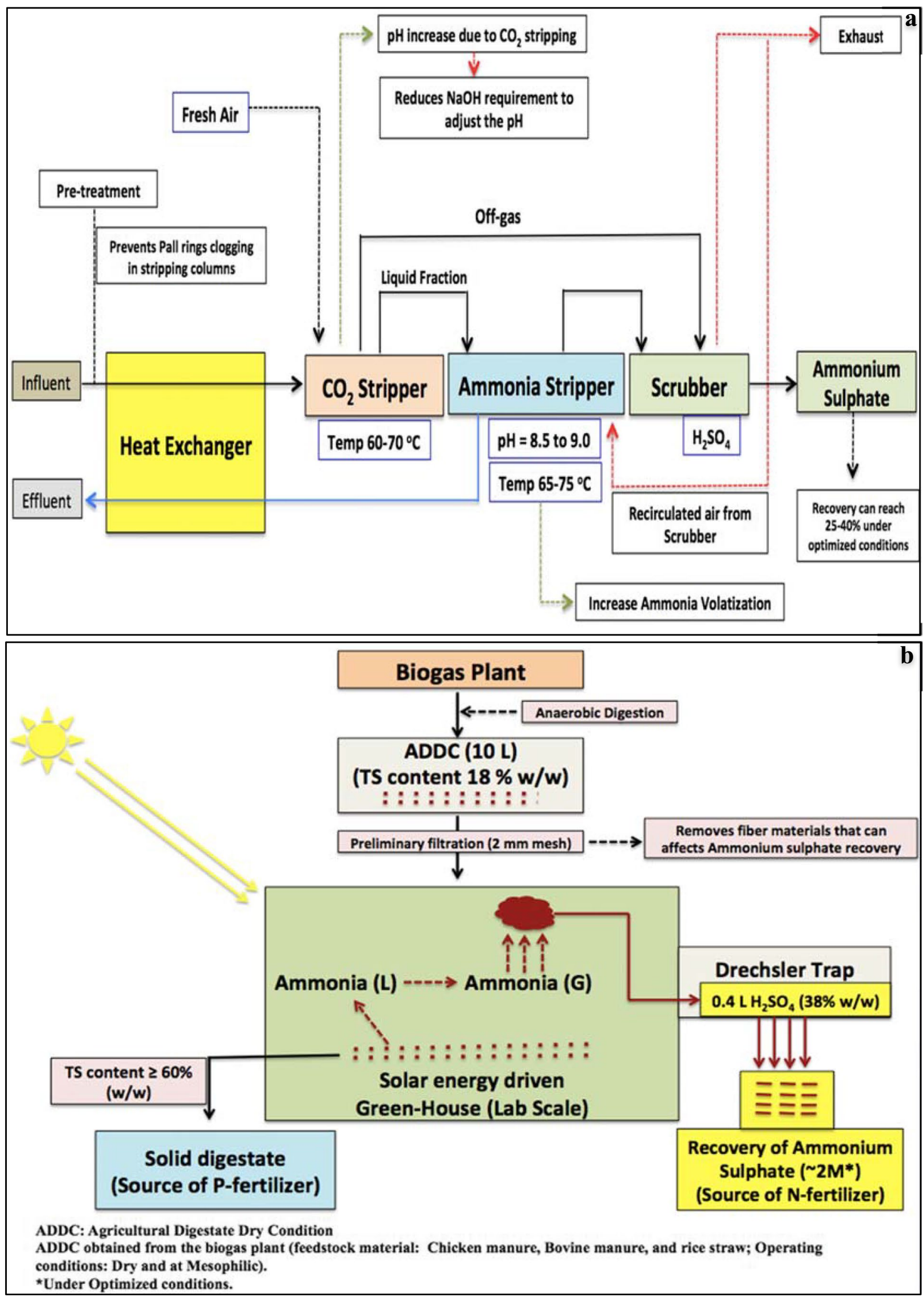
4Fig. 9 a The Nijhuis Ammonium Recovery System (amended and redrawn after [201]); b recovery of nitrogen as ammonium sulfate from the ADDC (conceptualized from [202])

et al. [215] in a biochar and struvite co-precipitation method recorded maximum recovery of $\mathrm{P}\left(45.36 \%\right.$ with $\left.\mathrm{ZnCl}_{2}\right)$ and $\mathrm{NH}_{4}{ }^{+}\left(33 \%\right.$ with $\left.\mathrm{NaHCO}_{3}{ }^{-}\right)$using rice biochar and Tongan sludge urban biochar respectively (adsorbent dose $=0.2 \mathrm{~g}$ ).

Biochar can be modified through different acid, alkaline, coating, magnetic, steam, and nanoparticle-based treatments for recovery of heavy metals, organic compounds, and nutrients such as nitrogen and phosphorous [214]. Biochar obtained from pyrolysis of anaerobic digestate of algae dairy manure upon treatment with $2 \mathrm{M} \mathrm{KOH}$ showed higher sorption $\left(50.71 \mathrm{mg} \mathrm{g}^{-1}\right)$ of $\mathrm{Cu}$ (II) as compared to untreated biochar $\left(21.12 \mathrm{mg} \mathrm{g}^{-1}\right)$ [216]. Hardwood biochar (114.2 mg $\mathrm{g}^{-1}$ ) showed maximum sorption capacity of ammonium as compared to corncobs $\left(108.9 \mathrm{mg} \mathrm{g}^{-1}\right)$ and mixed sawdust pellets $\left(24.7 \mathrm{mg} \mathrm{g}^{-1}\right.$ ) biochar from swine BGS (anaerobic digestate) (influent ammoniacal nitrogen concentration of $500 \mathrm{mg} \mathrm{L}^{-1}$, inflow rate $15 \mathrm{~mL} \mathrm{~min}^{-1}$ ) (pyrolysis temperature of $600{ }^{\circ} \mathrm{C}$ at $10{ }^{\circ} \mathrm{C} / \mathrm{min}$ for $8 \mathrm{~h}$ ) [217]. Kizito et al. [218] in another study reported maximum sorption capacity of ammonium by wood biochar $\left(44.64 \pm 0.602 \mathrm{mg} \mathrm{g}^{-1}\right)$ followed by rice husk biochar $\left(39.8 \pm 0.54 \mathrm{mg} \mathrm{g}^{-1}\right)$ from piggery bioslurry (anaerobic digestate) (influent ammoniacal nitrogen concentration of $1400 \mathrm{mg} \mathrm{L}^{-1}$ ) (pyrolysis temperature of $600{ }^{\circ} \mathrm{C}$ for $10 \mathrm{~h}$ ). Luo et al. [219] recovered $20 \%$ of nitrogen $\left(30 \mathrm{mg} \mathrm{L}^{-1} \mathrm{day}^{-1}\right)$ and $80 \%$ of phosphorous $\left(7 \mathrm{mg} \mathrm{L}^{-1}\right.$ day $^{-1}$ ) from BGS (piggery) using a novel photobioreactor under optimum operating conditions.

BGS have solid and liquid fractions, and to maximize their full potential as a nutrient source, the focus must be paid towards the exploitation of both these fractions. The LFD also aids bulkiness to the BGS and thereby limits its extensive applications in the agriculture fields as a consequence of challenges such as space limitations, long-term storage, and transportation. In general, LFD has low nutrient contents; hence, its further concentration or transforming to solid compounds has been recommended to facilitate the ease of transport [211]. It can also be amended with the mineral elements [35] and AIMs to develop value-added products. Additionally, the LFD can also be processed for the recovery of nitrogen; aiding to this, the latest technological developments have been reviewed and discussed [87, 201, 202]. The microalgal biomass harvested from such liquid fractions can also bioaccumulate N, P, and traces of micronutrients as well [13]. Sobhi et al. [220] explored heterotrophic indigenous microflora for the simultaneous achievement of biomass production $\left(>6 \mathrm{gL}^{-1}\right.$ with lipid, crude protein, ash content, and gross energy of $10.9 \%, 65 \%$, $10.7 \%$, and $19.6 \mathrm{MJ} \mathrm{kg}^{-1}$ respectively) and nutrient recovery ( $\sim 68 \%$ phosphate and $\sim 97 \%$ of total nitrogen) from the LFD.
Apart from the nutrient recovery, the resultant biomass can be further exploited as an animal feed or bioenergy feedstock. Thus, microalgal and microbial-based biosorption methodologies will be of great interest to serve multiple purposes such as wastewater treatment, generation of nutrientrich biomass, and potential feedstock for biofuel production.

\section{Review of commercial viability and economic estimates}

Interpretations of the BGS values can have multifaceted outlooks, such as economic fertilizer to agronomic estimates (Fig. 10). In beginning, the biofertilizer market has been reviewed to provide a brief overview of the existing market for organic agri-inputs. As per the biofertilizer market report (May 2021), the global market in 2021 for biofertilizers is estimated to be 2.6 billion USD, which is expected to be 4.5 billion USD by the year 2026 [222]. In another report published in June 2020 [223], the global biofertilizer market valued at 1.0 billion USD in 2019 is projected to achieve a CAGR of $12.8 \%$ from 2020 to 2027.

Moving to field valuations, an estimated return of INR 32400 can be obtained from the 10.8 ton of dried (25\% moisture) BGS (at INR 3 per kilogram) (biogas plant of $2 \mathrm{~m}^{3}$ capacity with daily feeding of $50 \mathrm{~kg}$ cattle dung and an equal amount of water, can produce 10.8 ton of dried BGS annually), as mentioned by [36]. Shaibur et al. [4] in their survey study on the utilization of CD in Ziala village (Satkhira District, Bangladesh) by sampled owners (twelve) estimated yearly savings of $10447 \mathrm{~kg}$ of chemical fertilizers, which is equal to 470115 Bangladeshi Taka per year ( 5547.97 USD, as of 17 May 2021, 14:32 UTC, Xe Currency converter). Rachmah et al. [224] reported the cost of bioslurry fertilizer between 520 and $1000 \mathrm{IDR} / \mathrm{kg}$ (equivalent to 0.037-0.070 USD, as of 15 May 2021, 18:12 UTC, Xe Currency converter) in their study in central Java (Indonesia) region during January-February 2020. While making economic estimates, an important factor is the handling and transportation cost associated with the BGS. We have reviewed some of the related studies to explore the transport options and related costs, though such costs vary and depend upon multiple factors such as available infrastructure, technologies for conditioning, processing, and management of slurry. In one of the earlier studies of Ghafoori et al. [225], the on-road transport cost of liquid digestate through truck ("standard $40 \mathrm{t}$ tandem trailer truck") (in Alberta, Canada) was estimated as $3.9 \mathrm{USD} \mathrm{t}^{-1}$ (distance fixed-cost) and 0.064 USD $\mathrm{t}^{-1} \mathrm{~km}^{-1}$ (distance variable cost) (refer to [225] for more details). Taking into account the cost associated with the feedstock material transport to the biogas plant, we have encountered a few studies. Zheng et al. [226] reviewed the economic scenario of one of the representative bio-natural 
Fig. 10 A schematic view representing prospective values of BGS (conceptualized from [221])

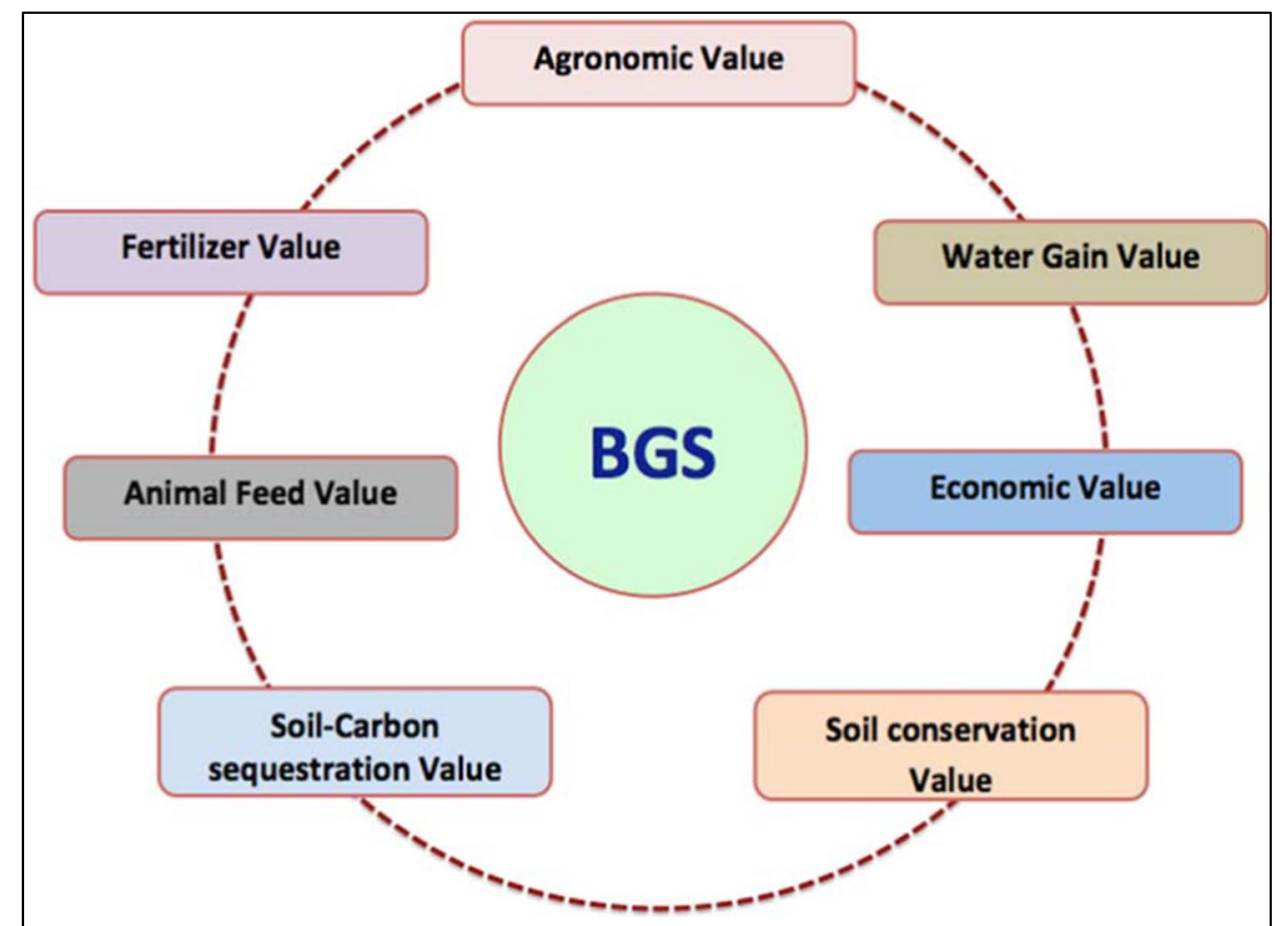

gas production projects in Europe; here the estimated cost for feedstock transport was mentioned as 6 Euro/t. According to Ghafoori et al. [225], transportation cost to bring feedstock (beef-cattle manure) material to a large-capacity centralized digester plant can be reduced using the pipeline as compared to the truck-based transport systems.

Utilization of LFD for recovery of nutrients can reduce the bulkiness of BGS and somehow the higher transportation cost as well [211]. The BGS enrichment studies and developing value-added products can be a considerable alternative to further reduce transport costs. Romero-Güiza et al. [13] reviewed the pelleting process for BGS solid fraction and cited that the price for the finished product can reach up to 250 euros per ton. Chen et al. [208] through vacuum-assisted gas-permeable membrane process of ammonia recovery estimated an additional benefit of 0.51 USD per kilogram of $\mathrm{N}$. Menkveld and Broeders [201] estimated the nitrogen recovery cost per kilogram ranges from 1.0 to 3.0 euros using the NAR system (efficiency between 80 and 90\%), while for Anammox (efficiency up to 75\%) and MBR (efficiency up to $75 \%$ ), they have mentioned the figures ranges from 1.5 to 3.0 and $>5.5$ euros respectively.

The highest benefit to cost ratio of 3.01 was reported in BGS enriched with Panchagavya (5 kg CD/BGS 12 ripe banana, $3 \mathrm{~L}$ tender coconut water, $1 \mathrm{~L}$ cow ghee/butter clarified, $3 \mathrm{~L}$ cow urine, and $2 \mathrm{~L}$ each of cow milk and curd) as compared to other organic treatments [130]. Rana et al. [227] performed bio-fortification of $\mathrm{Cu}, \mathrm{Zn}, \mathrm{Fe}$, and $\mathrm{Mn}$ with combined inoculation of bacterial and cyanobacterial strains in rice-wheat cropping sequence and recorded yield benefits of 40-60 kg N ha ${ }^{-1}$ savings (applied as urea) equivalent to 924-1386 USD (based on conservative estimates of area under rice and wheat crops in India and China).

Based on the NPK content in BGS, CM [33], N-DOC [228] (average value calculated from the multiple reported data), K-DOC [21], J-DOC, and J-BGS [229], economic values have been estimated theoretically (conceptualized from [221]). The price of N, P, and K fixed by the Department of Fertilizers, Ministry of Chemicals and Fertilizers, Govt. of India, under nutrient subsidy rates (NBS) per kilogram of N/P/K for the year 2020-2021 (Department of Fertilizers, Ministry of Chemicals and Fertilizers, Govt. of India) [230] was considered for the calculation. As observed from Fig. 11, value addition of BGS with DOCs resulted in higher $\mathrm{N}$ and $\mathrm{P}$ content, ensuring its higher price values as well.

Abdelwahab et al. [154] reported $\sim 38.20 \%$ higher biogas production from CM treated with FeNPs (15 $\mathrm{mgL}^{-1}$ ) during $\mathrm{AD}$, as compared to the control (CM without NP treatment). An increase in $\sim 1.16 \% \mathrm{~N}$ and $\sim 3.63 \%$ $\mathrm{K}$ was also noticed in recovered digestate (treated with FeNPs) as compared to control, though the P content was $0.94 \%$ less in treated digestate. Hassaneen et al. [182] recovered nutrient-enriched digestate from the AD of NPtreated (zinc ferrite, average crystallite size $6.22 \mathrm{~nm}$ ) CM. Interestingly, the recovered digestate (HRT-50 days) has higher $\mathrm{P}$ content $(3.50 \%)$ along with $\mathrm{N}$ and $\mathrm{K}$ content of $3.40 \%$ and $1.30 \%$ respectively. Abdelwahab et al. [231] in cost analysis for biogas production reported net gains of 20.6, 19.7, and 13.5 USD with NiNP supplementation at 2.0 (NiNPs-2.0), 1.0 (NiNPs-1.0), and 0.5 (NiNPs-0.5) 
Fig. 11 An economic value analysis of Organic manures based on the NPK content (A1: BGS, A2: CM; A3: BGS + N-DOC; A4: BGS+K-DOC; A5: BGS + J-DOC; A6: J-BGS; $\mathrm{CM}$ : cattle manure; N-DOC: neem deoiled cake; J-DOC: Jatropha deoiled cake; K-DOC: Karanja deoiled cake; BGS: biogas slurry from CM; J-BGS: BGS from the AD of J-DOC; combinations in $\mathrm{A} 3$ to $\mathrm{A} 6$ (50:50); MT: metric ton; INR: Indian rupees)

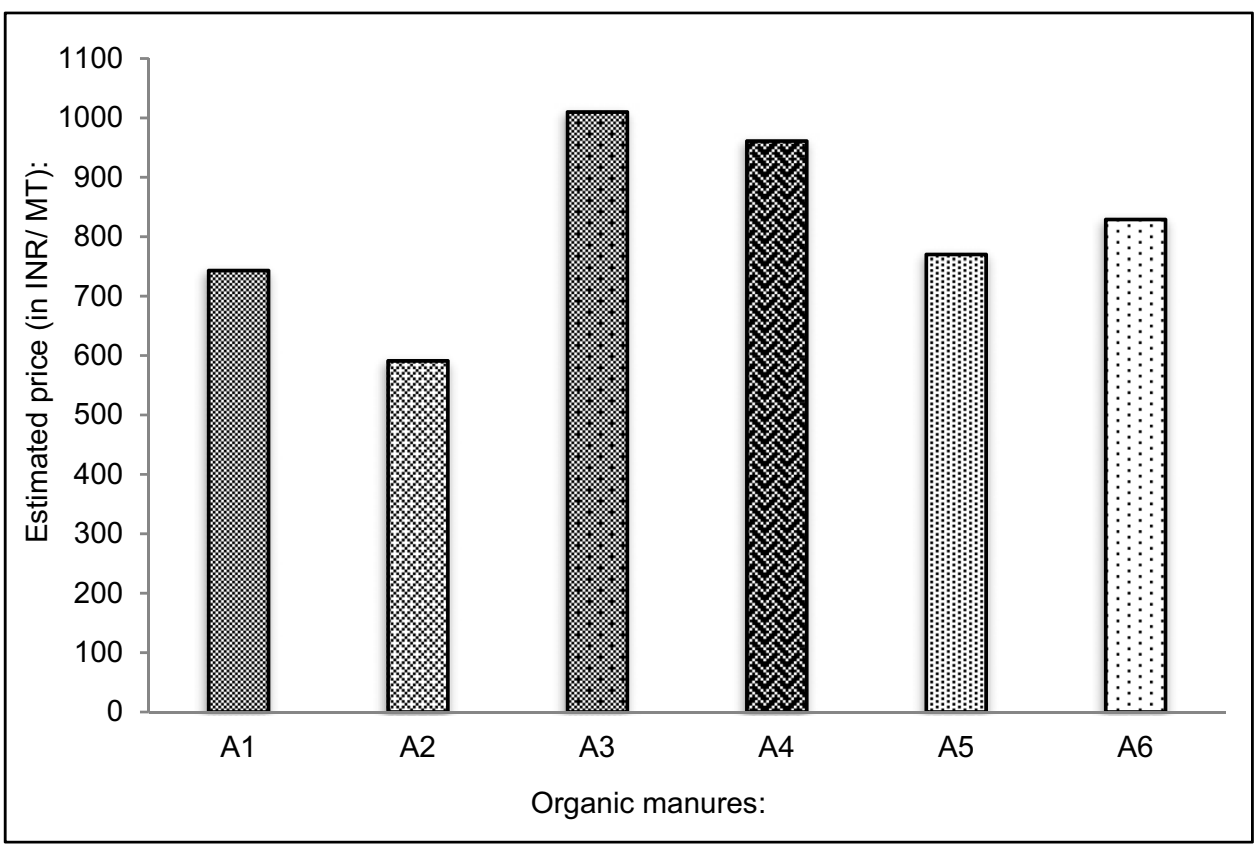

$\mathrm{mgL}^{-1}$ concentrations respectively. The estimated costs in NP synthesis (including chemicals) were $0.7,1.5$, and 3.1 USD with NiNPs-0.5, NiNPs-1.0, and NiNPs-2.0 respectively. Studies on ACD of BGS and DOCs coupled with NP supplementation will be of great interest for in situ recovery of nutrient-rich digestate and improved biogas yields. The recovered digestates can be further exploited as a suitable substrate for the mass multiplication of AIMs, owning to which bioformulations of the broad spectrum will be developed to meet the agriculture requirements. Additionally, the liquid fraction of digestate can also be processed for the recovery of nitrogen; aiding to this, the latest developments such as solar-driven technology [202], energy-efficient chemical stripping [201], and nanoparticle-assisted CANON process [87] have been discussed. The area is much promising and has immense potential to demonstrate multifaceted opportunities of generating greater revenues for the rural community where these resources (CD, BGS, DOCs) are in surplus availability. To further extend this, it is recommended to explore other associated values of BGS (mentioned in Fig. 10), as this will encourage the diverse stakeholders concerned to develop BGS-inspired value-added products that can act as a catalyst for rural development in terms of sustaining virtuous livelihood.

Some of the patents related to the recovery of resources from the BGS are mentioned below:

1. Patent title: Producing liquid fertilizer in a biogas plant. Publication number: US9957201. Publication date: 01 May 2018. Inventor: Liebeneiner, Rolf. Current Assignee: Bekon GMBH.
2. Patent title: Method for cycling biomasses between mushroom cultivation and anaerobic biogas fermentation, and for separating and drying a degassed biomass. Publication number: WO/2015/007290. Publication date: 22 Jan 2015. Inventors: Hoff, Svend Kristian and Pedersen, Lars Jørgen. Applicants: Advanced Substrate Technologies A/S.

3. Patent title: Lightweight assemblable appliance and respective method for production of biogas and liquid fertilizer. Publication number: WO/2014/203047. Publication date: 24 Dec 2014. Inventors: Efrati, Oshik Moshe; Teller, Yair; Lanzer, Erez; Miller, Yariv; Eilon, Tal; Zak, Shoham. Applicants: Ecogas Israel Ltd.

\section{Summary, perspectives, and conclusions}

The present review aims to cater the wider reader base, and efforts have been made to pay more attention towards the technical aspects linking to the conventional approaches to benefit the rural community and concerned stakeholders at large. The agricultural utilities of BGS have been covered in the post-introduction section of the manuscript. While gathering preliminary data during the literature survey, we have encountered some challenges that limit BGS applications in agriculture fields, despite the immense potential to compete with the available chemical and organic fertilizers and formulations of biocontrol activities. Here, we have reviewed the available literature and technological interventions in the area of bioslurry management and proposed some solutions with special reference to the bio/nanotechnology-based approaches aiding improvements and value addition to the 
BGS. BGS is the by-product of anaerobic digestion, where microbes are the key players, and hence we have focused our review towards microbially inspired approaches to upgrade the BGS. In situ value addition designated to the methodologies operated within the digester, while ex situ approaches deal with the recovered digestates.

To enhance the microbial activity during $\mathrm{AD}$ of biomass, the $\mathrm{C} / \mathrm{N}$ ratio is critical, which can be balanced through opting $\mathrm{ACD}$ of livestock manure with other organic materials such as NEDOCs. This, in addition, facilitates nutrientrich media for the microbial and enzymatic activities during digestion, which could serve twin benefits of improved BGSY and recovery of nutrient-enriched digestate. The mechanism of nanoparticle-microbe interaction was also taken into consideration and the possible routes to develop an understanding of how NPs influence the interspecies $\mathrm{H}_{2}$ transfer, and direct interspecies electron transfer, has been discussed. As per the reviewed literature, NPs such as FeNPs (nZVI) have been reported to have a potential role in establishing direct interspecies electron transfer between syntrophic bacteria and methanogens. FeNP interaction during $\mathrm{AD}$ also has considerable effects on reducing $\mathrm{H}_{2} \mathrm{~S}$ levels. Collectively, NP treatment facilitates higher biomethane yields with quality improvements and reduction in HRTs. In recent developments $[149,150]$, biomass material has been treated with laser irradiation coupled with nanoparticles during $\mathrm{AD}$ to achieve biostimulation of methanogens for improved biogas production.

To maximize the full potential of BGS as a nutrient source, both solid and liquid fractions need to be exploited. Recovery of nitrogen from the LFD is also a promising area to generate revenues. Several chemical methods have been reported for such recoveries; we have reviewed some of the latest and energy-efficient developments in the area (NAR system; V-GPM; solar energy-driven lab-scale greenhouse setup; hydrophobic membrane-based ammonia recovery system link coupled with an electromethanogenic microbial electrolysis cell; microalgal and microbial-based biosorption methodologies, etc.). Not only the biogas production; NPs can also be investigated for the recovery/removal of nitrogen from the digestates. In one such study, Zhang et al. [87] studied the role of $\mathrm{ZnO}$ NPs on the removal of nitrogen from the sludge in the CANON process. Here they have found $\mathrm{ZnO} N \mathrm{NPs}$ enhance the functioning of ANOB and AAOB, and suppress the activity of $\mathrm{NOB}$, leading to improvements in nitrogen removal. After recovery/removal of nitrogen from the LFD, the solid digestate can serve as a rich source of phosphorus fertilizer.

Taking the account of post-recovery amendments in the BGS, we have reviewed the research efforts in the area of biomass conversion and waste valorization to develop conceptual understanding and technical realizations of the plausible strategies. For developing BGS-derived products, another key challenge is the consistent quality of the slurry. There must be quality parameters for the procurement of BGS from various stakeholders. Rath and Joshi [35] recommended electrical conductivity and dissolved solid contents as two preferable parameters for on-site quality assessment of BGS. However, extensive studies are required to standardize the methods of BGS quality assessment and consequently the cost as per quality.

Referring to Fig. 11, it has been demonstrated through the theoretical calculations that adding NEDOCs can improve nutrient levels (such as $\mathrm{N}$ and $\mathrm{P}$ ) in BGS. The combined formulations of BGS and NEDOCs (optimized ratios) can be utilized as a nutrient-enriched low-cost substrate for the mass multiplication of AIMs. Such investigations can potentially be replaced the requirements of expensive carbon sources such as sucrose to achieve the ideal $\mathrm{C} / \mathrm{N}$ ratio for microbial growth during solid-state fermentation [39]. Bioprospecting of the beneficial microbes through multisubstrate interactions can also be done to produce bioactive compounds offering anti-phytopathogenic activities. Further research is recommended in the area of developing sustainable feedstock combinations (BGS amended with different NEDOCs) through optimization studies to produce platform chemicals. The expense of resources in phase fractionation (separation of solid and liquid phases) of BGS can also be reduced through the enrichment strategies using DOCs and AIMs.

The role of NPs in biostimulation of microbial activities during $\mathrm{AD}$ with opportunities and challenges to improve biogas yields coupled with the recovery of quality digestates is discussed in Section 3.3. Interestingly, we have also found reports on the synthesis of nanoparticles from NEDOCs such as Madhuca latifolia [232] and Jatropha curcas [233]. Hence, NEDOCs and BGS can be further explored as low-cost reducing and capping agents for the synthesis of nanoparticles. Application of such biofabricated nanomaterials in the improvement of $\mathrm{AD}$ of biomass waste, product recovery, and value addition of BGS will substantially encourage greener, eco-friendly, and economically viable routes to transform challenges into opportunities in the real world. Adding to this, several studies are available that report application of NPs (at low/optimized dose) in promoting microbial activity. Hence, it could be an innovative approach for the researchers to explore the possibilities of utilizing BGS enriched formulations (a) to deliver AIMs and nanoparticles to the plants, (b) to stimulate the process of vermicomposting, etc. However, the valorization methodologies inspired by nanotechnology-based approaches have the risk of nanotoxicity on the environment and ecosystem concerned. In this regard, we have reviewed the life-cycle analysis studies to access the environmental impacts of such introductions. In one such study, Hijazi et al. [192] reported that the environmental impact of electricity production from 
the nanoparticle (CoNPs, NiNPs, FeNPs, and $\mathrm{Fe}_{3} \mathrm{O}_{4} \mathrm{NPs}$ )treated biomass was lesser as compared to the untreated biomass (control). Hassanein et al. [198] fertilized Lactuca sativa with the diluted effluent recovered from the digester fed with NP mixture (FeNPs $1000 \mathrm{mgL}^{-1}$, NiNPs 120 $\mathrm{mgL}^{-1}$, and CoNPs $54 \mathrm{mgL}^{-1}$ ), and reported higher levels of $\mathrm{N}, \mathrm{P}, \mathrm{K}, \mathrm{Zn}, \mathrm{Mn}, \mathrm{Cu}$, and $\mathrm{Na}$ in the plant biomass which could be due to the increased nutrient uptake and translocation efficiency as a consequence of NP treatment. The recorded values of $\mathrm{Fe}, \mathrm{Ni}$, and $\mathrm{Co}$ in the plant biomass were below the reported toxic limits.

While reviewing the available reports, it has been observed that one of the reasons behind the toxicity of NPs is attributed to their aqueous solubility (AQS) [147]. To extenuate the effect of nanotoxicity during $\mathrm{AD}$, nanoparticle coaggregation can be explored, which is reported to decrease the availability of free ions in the aqueous medium, thus capable of reducing toxic effects. We have also compared the influence of nanoparticles and their bulk counterparts on the AD during biogas production. Studies favored NP application, though it has also been realized that certain aspects of NPs such as concentration, size, type, and biomass material to which NPs acted upon and their interaction with other trace elements/NPs (hetero-aggregation) in the system are of key significance, and hence application-based optimization studies are critical to prevent their (NPs) overexploitation and related environmental consequences thereof. In AD systems, the presence of antibiotics (norfloxacin, and sulfamethazine) can escalate the toxicity potential of NPs (such as ZnO NPs) [234]. Hence, apart from nanotoxicity, the risk of other emerging complex pollutants will also be concerned and investigated further. Tang et al. [27] reported a low risk of pollution with the repeated applications of BGS in crop fields. However, detailed studies are warranted for comparative assessment of heavy metals, pathogens, pesticides, and other contaminants present in digested (BGS) and undigested manures.

The valuation of BGS has multifaceted outlooks, ranging from agronomic to economic values. BGS and its derived products (such as solid pellets, liquid fertilizer, organic composts, and other value-added products) are in great demand as they offer multiple benefits to the soil and plants, hence considered one of the preferred bio-agri input for organic farmers. Some of the bioslurry-based products are already available in the market [35]. The economic benefits associated with the BGS application in agriculture fields have been reviewed [3, 13, 36, 130, 224]. Talking about commercial viability, competition with the available conventional fertilizers and some consumers also has negative perception towards digestates [13] limits their market acceptance. However, the technical limitations for such observations are covered in earlier sections. There is a need to develop more robust models for the economic and agronomic assessments of such biomass wastes. Integrated studies based on bio/ nanotechnology interventions can promote niche development for generating the value-added products from different waste biomass of agriculture origin, thus promoting rural development and benefiting society at large. Overall, it has been concluded that chemical fertilizers are considered a readily available form of nutrients to the crop plants, though their extensive usage in agriculture fields reportedly has adverse impacts on normal ecological functioning at various levels. The area of organic farming is traditionally in use, much promising, and diverse but emerging challenges like effectivity, productivity, and commercial exploitation precisely with the use of organic manures derived from livestock wastes processing such as BGS need further attention. Here, based on an extensive literature survey and critical assessment of available information to the best of our access, we have proposed integrated approaches for improving the agriculture potential of BGS, which is principally an amalgamation of applied aspects of bio/nanotechnology.

Author contribution AK: writing-original draft preparation, editing, methodology; LMV: visualization, writing —editing; SS and NS: conceptualization; writing - review and editing; supervision. All authors have read and agreed to the published version of the manuscript.

Data availability Not applicable.

Code availability Not applicable.

\section{Declarations}

Ethics approval Not applicable.

Informed consent statement Not applicable.

Consent for publication Not applicable.

Conflict of interest The authors declare no competing interests.

\section{References}

1. Pindi PK, Satyanarayana SDV (2012) Liquid microbial consortium- a potential tool for sustainable soil health. J Biofertil Biopestici 03https://doi.org/10.4172/2155-6202.1000124

2. Willer H, Schlatter B, Trávníček J, Kemper L, Lernoud J (Eds.) (2020) The world of organic agriculture. Statistics and emerging trends 2020 (pp. 1-333). Research Institute of Organic Agriculture (FiBL), Frick, and IFOAM-Organics International, Bonn. http://www.organic-world.net/yearbook/yearbook-2020. html (Accessed 3 Jan 2022)

3. Ramesh P, Panwar NR, Singh AB, Ramana S, Yadav SK, Shrivastava R, Rao AS (2010) Status of organic farming in India. Current Science 98:1190-1194

4. Shaibur MR, Husain H, Arpon SH (2021) Utilization of cow dung residues of biogas plant for sustainable development of a 
rural community. Curr Res Environ Sustain 3:100026. https:// doi.org/10.1016/j.crsust.2021.100026

5. Gupta KK, Aneja KR, Rana D (2016) Current status of cow dung as a bioresource for sustainable development. Bioresour Bioprocess 3:28. https://doi.org/10.1186/s40643-016-0105-9

6. Zheng X, Fan J, Xu L, Zhou J (2017) Effects of combined application of biogas slurry and chemical fertilizer on soil aggregation and $\mathrm{C} / \mathrm{N}$ distribution in an Ultisol. PLoS ONE 12:e0170491. https://doi.org/10.1371/journal.pone.0170491

7. Hazarika S, Barooah MJ, Dutta PK, Rajkhowa P (2015) Enriched biogas slurry: a potential source of nutrients for organic farming. Akshay Urja, October 2015, 26-29

8. Koirala K (2013) Characterization of ammonia volatilization from liquid dairy manure. PhD. Thesis. Department of Biological Systems Engineering, Washington State University, Washington

9. Xu W, Zhu Y, Wang X et al (2021) The effect of biogas slurry application on biomass production and forage quality of Lolium multiflorum. Sustainability 13:3605. https://doi.org/10.3390/ su13073605

10. Kumar S, Malav LC, Malav MK, Khan SA (2015) Biogas slurry: source of nutrients for eco-friendly agriculture. Int J Ext Res 2:42-46

11. Devarenjan J, Joselin-Herbert GM, Amutha D (2019) Utilization of bioslurry from biogas plant as fertilizer. Int J Recent Technol Eng 8:12210-12213

12. Aminul Haque ABM (2013) Bio slurry ultimate choice of biofertilizer. Open Access Sci Rep 2:738https://doi.org/10.4172/scien tificreports 738

13 Romero-Güiza MS, Mata Alvarez J et al (2016) Nutrient recovery technologies for anaerobic digestion systems: an overview. Rev Ion 29:7-26. https://doi.org/10.18273/revion. v29n1-2016001

14. Bonten LTC, Zwart KB, Rietra, RPJJ, Postma R, de Haas MJG (2014) Is bio-slurry from household digesters a better fertilizer than manure? A literature review. Wageningen, Alterra Wageningen UR (University \& Research Centre), Alterra report 2519, pp. 46

15. Niyungeko C, Liang X, Liu C et al (2018) Effect of biogas slurry application rate on colloidal phosphorus leaching in paddy soil: a column study. Geoderma 325:117-124. https://doi.org/10.1016/j. geoderma.2018.03.036

16. Rahaman MA, Zhan X, Zhang Q et al (2020) Ammonia volatilization reduced by combined application of biogas slurry and chemical fertilizer in maize-wheat rotation system in North China Plain. Sustainability 12:4400. https://doi.org/10.3390/ su12114400

17. Warnars L, Oppenoorth H (2014) Bioslurry: a supreme fertiliser. A Study on Slurry results and uses. https://www.ourenergypolicy. org/wp-content/uploads/2014/05/bioslurry.pdf (Accessed 16 May 2021)

18. Möller K, Stinner W (2009) Effects of different manuring systems with and without biogas digestion on soil mineral nitrogen content and on gaseous nitrogen losses (ammonia, nitrous oxides). Eur J Agron 30:1-16. https://doi.org/10.1016/j.eja.2008. 06.003

19. Groot LD, Bogdanski A (2013) Bioslurry=brown gold? A review of scientific literature on the co-product of biogas production. Environment and Natural Resources Management Working Paper. Climate, Energy and Tenure Division (NRC) publications. Food and Agriculture Organization of the United Nations (FAO). https://www.fao.org/3/i3441e/i3441e.pdf (Accessed 3 Jan 2022)

20. Liao C, Tian Q, Liu F (2021) Nitrogen availability regulates deep soil priming effect by changing microbial metabolic efficiency in a subtropical forest. J For Res 32:713-723. https://doi.org/10. 1007/s11676-020-01148-0
21. Insam H, Gómez-Brandón M, Ascher J (2015) Manure-based biogas fermentation residues - friend or foe of soil fertility? Soil Biol Biochem 84:1-14. https://doi.org/10.1016/j.soilbio.2015.02. 006

22. Stumpe B, Werner S, Jung R et al (2012) Organic carbon dynamics and enzyme activities in agricultural soils amended with biogas slurry, liquid manure and sewage sludge. Agric Sci 3:104-113. https://doi.org/10.4236/as.2012.31014

23. Senbayram M, Chen R, Mühling KH, Dittert K (2009) Contribution of nitrification and denitrification to nitrous oxide emissions from soils after application of biogas waste and other fertilizers. Rapid Commun Mass Spectrom 23:2489-2498. https://doi.org/ 10.1002/rcm.4067

24. Liu W, Qiao C, Yang S et al (2018) Microbial carbon use efficiency and priming effect regulate soil carbon storage under nitrogen deposition by slowing soil organic matter decomposition. Geoderma 332:37-44. https://doi.org/10.1016/j.geoderma. 2018.07.008

25. Tang Y, Luo L, Carswell A et al (2021) Changes in soil organic carbon status and microbial community structure following biogas slurry application in a wheat-rice rotation. Sci Total Environ 757:143786. https://doi.org/10.1016/j.scitotenv.2020.143786

26. Chen L, Liu L, Mao C et al (2018) Nitrogen availability regulates topsoil carbon dynamics after permafrost thaw by altering microbial metabolic efficiency. Nat Commun 9:3951. https://doi. org/10.1038/s41467-018-06232-y

27. Tang Y, Wang L, Carswell A et al (2020) Fate and transfer of heavy metals following repeated biogas slurry application in a rice-wheat crop rotation. J Environ Manag 270:110938. https:// doi.org/10.1016/j.jenvman.2020.110938

28. Bian B, Lin C, Lv L (2016) Health risk assessment of heavy metals in soil-plant system amended with biogas slurry in Taihu basin, China. Environ Sci Pollut Res 23:16955-16964. https:// doi.org/10.1007/s11356-016-6712-3

29. Lu J, Jiang L, Chen D et al (2012) Decontamination of anaerobically digested slurry in a paddy field ecosystem in Jiaxing region of China. Agric Ecosyst Environ 146:13-22. https://doi.org/10. 1016/j.agee.2011.10.011

30. Goux X, Calusinska M, Fossépré M et al (2016) Start-up phase of an anaerobic full-scale farm reactor-appearance of mesophilic anaerobic conditions and establishment of the methanogenic microbial community. Bioresour Technol 212:217-226. https:// doi.org/10.1016/j.biortech.2016.04.040

31. Wirth R, Kovács E, Maróti G, Bagi Z, Rákhely G, Kovács KL (2012) Characterization of a biogas-producing microbial community by short-read next generation DNA sequencing. Biotechnol Biofuels 5:41. https://doi.org/10.1186/1754-6834-5-41

32. Werner U, Stöhr U, Hees N (1989) Biogas plants in animal husbandry. Deutsches Zentrum für EntwicklungstechnologienGATE, a Division of the Deutsche Gesellschaft für Technische Zusammenarbeit (GTZ) GmbH. https://sswm.info/sites/default/ files/reference_attachments/WERNER\%201989\%20Biogas\% 20plants\%20in\%20Animal\%20Husbandry.pdf (Accessed 03 Jan 2022)

33. Mdlambuzi T, Muchaonyerwa P, Tsubo M, Moshia ME (2021) Nitrogen fertiliser value of biogas slurry and cattle manure for maize (Zea mays L.) production. Heliyon 7:e07077. https://doi. org/10.1016/j.heliyon.2021.e07077

34. Thiruselvi D, Kumar PS, Kumar MA et al (2021) A critical review on global trends in biogas scenario with its up-gradation techniques for fuel cell and future perspectives. Int J Hydrogen Energy 46:16734-16750. https://doi.org/10.1016/j.ijhydene. 2020.10.023

35. Rath D, Joshi YC (2020) A holistic manure management model by leveraging dairy cooperative network. Int J Rural Manag 16:131-155. https://doi.org/10.1177/0973005220950520 
36. Sharma D, Samar K (2016) Frequently asked questions on biogas technology. Biogas development and training centre, Department of Renewable Energy Engineering, College of Technology and Engineering, Maharana Pratap University of Agriculture \& Technology, Udaipur (Raj.), 1-62. https://www.ctae.ac.in/ images/editorFiles/file/CTAE-2017/Biogas\%20FAQ_English. pdf (Accessed 03 Jan 2022)

37. Xu C, Tian Y, Sun Y, Dong L (2013) Effects of biogas slurry irrigation on growth, photosynthesis, and nutrient status of Perilla frutescens seedlings. Commun Soil Sci Plant Anal 44:33813390. https://doi.org/10.1080/00103624.2013.847447

38. Jared N, Erastus G, Christopher N, Steve A (2016) Evaluation of biogas slurry as an alternative organic fertilizer: a case study in Kenya. Int J Ext Res 9:10-14

39. Sharma A, Sharma S, Sabir N et al (2021) Impact assessment of Karanja deoiled cake and sundried biogas slurry as a mixed substrate on the nematicidal potential of Purpureocillium lilacinum. J King Saud Univ-Sci 33:101399. https://doi.org/10.1016/j.jksus. 2021.101399

40 Goswami R, Chattopadhyay P, Shome A et al (2016) An overview of physico-chemical mechanisms of biogas production by microbial communities: a step towards sustainable waste management. 3 Biotech 6:72. https://doi.org/10.1007/s13205-016-0395-9

41. Njogu P, Kinyua R, Muthoni P, Nemoto Y (2021) Biogas production using water hyacinth (Eicchornia crassipes) for electricity generation in Kenya. http://ir.jkuat.ac.ke/handle/123456789/ 5477 (Accessed 25 May 2021)

42. Marsaulina G, Taufikurahman T, Rahmawati A (2021) Biocomposites from anaerobically digested Eichhornia crassipes (Mart.) Solms), as an alternative solution for the post-phytoremediation process. Curr Res Biosci Biotech 2:139-144. https://doi.org/10. 5614/crbb.2021.2.2/ZLCB2984

43. Patil JH, Antonyraj M, Gavimath CC, Hooli VR (2011) A comparative study on anaerobic co-digestion of water hyacinth with poultry litter and cow dung. Int J Chem Sci Appl 2:148-155

44. Odhner PB, Horváth IS, Kabir MM, Schabbauer A (2012) Biogas from lignocellulosic biomass. Rapport SGC 247. ISRN SGC-R247-SE. http://www.sgc.se/ckfinder/userfiles/files/SGC247.pdf (Last Accessed 03 Jan 2022)

45. Rodríguez-Abalde Á, Guivernau M, Prenafeta-Boldú FX et al (2019) Characterization of microbial community dynamics during the anaerobic co-digestion of thermally pre-treated slaughterhouse wastes with glycerin addition. Bioprocess Biosyst Eng 42:1175-1184. https://doi.org/10.1007/s00449-019-02115-8

46. Wei L, Qin K, Ding J et al (2019) Optimization of the co-digestion of sewage sludge, maize straw and cow manure: microbial responses and effect of fractional organic characteristics. Sci Rep 9:2374. https://doi.org/10.1038/s41598-019-38829-8

47. Priya P, Nikhitha SO, Anand C et al (2018) Biomethanation of water hyacinth biomass. Bioresour Technol 255:288-292. https:// doi.org/10.1016/j.biortech.2018.01.119

48. Iocoli GA, Zabaloy MC, Pasdevicelli G, Gómez MA (2019) Use of biogas digestates obtained by anaerobic digestion and co-digestion as fertilizers: characterization, soil biological activity and growth dynamic of Lactuca sativa L. Sci Total Environ 647:11-19. https://doi.org/10.1016/j.scitotenv.2018.07.444

49. Wang S, Ma F, Ma W, Wang P, Zhao G, Lu X (2019) Influence of temperature on biogas production efficiency and microbial community in a two-phase anaerobic digestion system. Water 11:133. https://doi.org/10.3390/w11010133

50. Zealand AM, Mei R, Papachristodoulou P, Roskilly AP, Liu WT, Graham DW (2018) Microbial community composition and diversity in rice straw digestion bioreactors with and without dairy manure. Appl Microbiol Biotechnol 102:8599-8612. https://doi.org/10.1007/s00253-018-9243-7
51. Stolze Y, Zakrzewski M, Maus I et al (2015) Comparative metagenomics of biogas-producing microbial communities from production-scale biogas plants operating under wet or dry fermentation conditions. Biotechnol Biofuels 8:14. https://doi.org/ 10.1186/s13068-014-0193-8

52. Möller K (2015) Effects of anaerobic digestion on soil carbon and nitrogen turnover, $\mathrm{N}$ emissions, and soil biological activity. A review. Agron Sustain Dev 35:1021-1041. https://doi.org/10. 1007/s13593-015-0284-3

53. Smith J, Abegaz A, Matthews RB et al (2014) What is the potential for biogas digesters to improve soil fertility and crop production in Sub-Saharan Africa? Biomass Bioenergy 70:58-72. https://doi.org/10.1016/j.biombioe.2014.02.030

54. Wentzel S, Joergensen RG (2016) Effects of biogas and raw slurries on grass growth and soil microbial indices. J Plant Nutr Soil Sci 179:215-222. https://doi.org/10.1002/jpln.201400544

55. Tumuhimbise K (2021) Effects of bio-digestion on the quality of cattle bio-slurry and yield of radish on a Ferralsol in central Uganda (Doctoral dissertation, Makerere University)

56. Thomsen IK (2000) $\mathrm{C}$ and $\mathrm{N}$ transformations in $15 \mathrm{~N}$ crosslabelled solid ruminant manure during anaerobic and aerobic storage. Bioresour Technol 72:267-274. https://doi.org/10.1016/ S0960-8524(99)00114-5

57. Peng X, Zhu QH, Xie ZB et al (2016) The impact of manure, straw and biochar amendments on aggregation and erosion in a hillslope Ultisol. Catena 138:30-37. https://doi.org/10.1016/j. catena.2015.11.008

58. You L, Yu S, Liu H et al (2019) Effects of biogas slurry fertilization on fruit economic traits and soil nutrients of Camellia oleifera Abel. PLoS ONE 14:e0208289. https://doi.org/10.1371/ journal.pone. 0208289

59. Devakumar N, Shubha S, Rao GGE, Gowda SB (2014) Multiplication of bio-control agents on locally available organic media. In: Proceedings of the 4th ISOFAR Scientific Conference. 'Building Organic Bridges'. Organic World Congress 2014, 13-15 Oct., Istanbul, Turkey, Eds: Rahmann G, Aksoy U, eprint ID 23622

60. Zhao H, Li J, Liu J et al (2013) Microbial community dynamics during biogas slurry and cow manure compost. J Integr Agric 12:1087-1097. https://doi.org/10.1016/S2095-3119(13)60488-8

61. Xu M, Xian Y, Wu J, Gu Y, Yang G, Zhang X, Peng H, Yu X, Xiao Y, Li L (2019) Effect of biogas slurry addition on soil properties, yields, and bacterial composition in the rice-rape rotation ecosystem over 3 years. J Soils Sediments 19:2534-2542. https:// doi.org/10.1007/s11368-019-02258-x

62. Ferdous Z, Ullah H, Datta A et al (2018) Yield and profitability of tomato as influenced by integrated application of synthetic fertilizer and biogas slurry. Int J Veg Sci 24:445-455. https:// doi.org/10.1080/19315260.2018.1434585

63. Jothi G, Pugalendhi S, Poornima K, Rajendran G (2003) Management of root-knot nematode in tomato Lycopersicon esculentum, Mill., with biogas slurry. Bioresour Technol 89:169-170. https:// doi.org/10.1016/S0960-8524(03)00047-6

64. Garg RN, Pathak H, Das DK, Tomar RK (2005) Use of flyash and biogas slurry for improving wheat yield and physical properties of soil. Environ Monit Assess 107:1-9. https://doi.org/10.1007/ s10661-005-2021-x

65. Zhao Y, Yang QS, Yang S et al (2014) Effects of biogas slurry pretreatment on germination and seedling growth of Vicia faba L. AMR 955-959:208-212. https://doi.org/10.4028/www.scien tific.net/AMR.955-959.208

66. Du Z, Xiao Y, Qi X et al (2018) Peanut-shell biochar and biogas slurry improve soil properties in the North China Plain: a fouryear field study. Sci Rep 8:13724. https://doi.org/10.1038/ s41598-018-31942-0 
67. Coelho JJ, Hennessy A, Casey I et al (2020) Biofertilisation with anaerobic digestates: effects on the productive traits of ryegrass and soil nutrients. J Soil Sci Plant Nutr 20:1665-1678. https:// doi.org/10.1007/s42729-020-00237-7

68. Koszel M, Lorencowicz E (2015) Agricultural use of biogas digestate as a replacement fertilizers. Agric Agric Sci Procedia 7:119-124. https://doi.org/10.1016/j.aaspro.2015.12.004

69. Yu F-B, Luo X-P, Song C-F, Zhang M-X, Shan S-D (2010) Concentrated biogas slurry enhanced soil fertility and tomato quality. Acta Agric Scand Section B Soil Plant Sci 60:262-268. https:// doi.org/10.1080/09064710902893385

70. Thomas BW, Li X, Nelson V, Hao X (2017) Anaerobically digested cattle manure supplied more nitrogen with less phosphorus accumulation than undigested manure. Agron J 109:836-844. https://doi.org/10.2134/agronj2016.12.0719

71. Pan Z, Qi G, Andriamanohiarisoamanana FJ et al (2018) Potential of anaerobic digestate of dairy manure in suppressing soilborne plant disease. Anim Sci J 89:1512-1518. https://doi.org/ 10.1111/asj.13092

72. Min YY, Toyota K, Sato E, Takada A (2011) Effects of anaerobically digested slurry on Meloidogyne incognita and Pratylenchus penetrans in tomato and radish production. Appl Environ Soil Sci 2011:1-6. https://doi.org/10.1155/2011/528712

73. Kupper KC, Bettiol W, de Goes A et al (2006) Biofertilizer for control of Guignardia citricarpa, the causal agent of citrus black spot. Crop Protect 25:569-573. https://doi.org/10.1016/j.cropro. 2005.09.002

74. Islam MR, Rahman SME, Rahman MM, Oh DH, Ra CS (2010) The effects of biogas slurry on the production and quality of maize fodder. Turk J Agric For 34:91-99. https://doi.org/10. 3906/tar-0902-44

75. https://www.goldstandard.org/projects/use-bio-slurry-ferti lizer-indonesia-domestic-biogas-programme (Accessed 16 May 2021)

76. Sumbul A, Rizvi R, Mahmood I, Ali Ansari R (2015) Oil-cake amendments: useful tools for the management of phytonematodes. Asian J of Plant Pathol 9:91-111. https://doi.org/10.3923/ ajppaj.2015.91.111

77. Aziz Y, Shah GA, Rashid MI (2019) ZnO nanoparticles and zeolite influence soil nutrient availability but do not affect herbage nitrogen uptake from biogas slurry. Chemosphere 216:564-575. https://doi.org/10.1016/j.chemosphere.2018.10.119

78. Faisal S, Yusuf Hafeez F, Zafar Y et al (2018) A review on nanoparticles as boon for biogas producers-nano fuels and biosensing monitoring. Appl Sci 9:59. https://doi.org/10.3390/ app9010059

79. Kharitonov S, Semenov M, Sabrekov A et al (2021) Microbial communities in methane cycle: modern molecular methods gain insights into their global ecology. Environments 8:16. https://doi. org/10.3390/environments8020016

80. Wang Y, Qian P-Y (2009) Conservative fragments in bacterial 16S rRNA genes and primer design for $16 \mathrm{~S}$ ribosomal DNA amplicons in metagenomic studies. PLoS ONE 4:e7401. https:// doi.org/10.1371/journal.pone.0007401

81. Han R, Liu L, Meng Y et al (2021) Archaeal and bacterial community structures of rural household biogas digesters with different raw materials in Qinghai Plateau. Biotechnol Lett 43:13371348. https://doi.org/10.1007/s10529-021-03105-1

82. Behera SS, Ray RC (2021) Bioprospecting of cowdung microflora for sustainable agricultural, biotechnological and environmental applications. Curr Res Microbial Sci 2:100018. https:// doi.org/10.1016/j.crmicr.2020.100018

83. Sun L, Pope PB, Eijsink VGH, Schnürer A (2015) Characterization of microbial community structure during continuous anaerobic digestion of straw and cow manure. Microbial Biotechnol 8:815-827. https://doi.org/10.1111/1751-7915.12298
84. Christy PM, Gopinath LR, Divya D (2014) Microbial dynamics during anaerobic digestion of cow dung. Int J Plant Anim Environ Sci 4:86-94

85. Wang S, Chen L, Yang H, Liu Z (2021) Influence of zinc oxide nanoparticles on anaerobic digestion of waste activated sludge and microbial communities. RSC Adv 11:5580-5589. https://doi. org/10.1039/D0RA08671A

86. Ning J, Zhou M, Pan X et al (2019) Simultaneous biogas and biogas slurry production from co-digestion of pig manure and corn straw: performance optimization and microbial community shift. Bioresour Technol 282:37-47. https://doi.org/10.1016/j. biortech.2019.02.122

87. Zhang X, Zhang N, Fu H et al (2017) Effect of zinc oxide nanoparticles on nitrogen removal, microbial activity and microbial community of CANON process in a membrane bioreactor. Bioresour Technol 243:93-99. https://doi.org/10.1016/j.biortech.2017. 06.052

88. Lu H, Wang X, Zhang K et al (2014) Identification and nematicidal activity of bacteria isolated from cow dung. Ann Microbiol 64:407-411. https://doi.org/10.1007/s13213-013-0660-7

89. Radha TK, Rao DLN (2014) Plant growth promoting bacteria from cow dung based biodynamic preparations. Indian J Microbiol 54:413-418. https://doi.org/10.1007/s12088-014-0468-6

90. Paikray SP, Malik, VS (2012) Novel formulation of microbial consortium based bioinoculant for wide spread use in agriculture practices. US Patent US20120015806A1 Jan 2012

91. Game BC, Deokar CD, More PE (2017) Efficacy of newly developed microbial consortium for composting of rural and urban wastes. Int J Curr Microbiol App Sci 6:626-633. https://doi.org/ 10.20546/ijcmas.2017.606.074

92. Kavya Y, Vijaya Gopal A, Subhash Reddy R, Sreedhar M (2016) Enrichment of biogas manures with beneficial microorganisms. Int J Curr Microbiol App Sci 5:242-252. https://doi.org/10. 20546/ijcmas.2016.507.025

93. Karmegam N, Rajasekar K (2012) Enrichment of biogas slurry vermicompost with Azotobacter chroococcum and Bacillus megaterium. J Environ Sci Technol 5:91-108. https://doi.org/ 10.3923/jest.2012.91.108

94. Johansen A, Carter MS, Jensen ES et al (2013) Effects of digestate from anaerobically digested cattle slurry and plant materials on soil microbial community and emission of $\mathrm{CO}_{2}$ and $\mathrm{N}_{2} \mathrm{O}$. Appl Soil Ecol 63:36-44. https://doi.org/10.1016/j.apsoil.2012. 09.003

95. Chandra R, Vijay VK, Subbarao PMV (2009) Biogas production from de-oiled seed cakes of Jatropha and Pongamia. Renew Energy (Akshay Urja) 3:17-22

96. Marathe AB, Deshmukh M (2013) Synthesis of biofuel from non-edible deoiled cakes. Int J Eng Res Technol 2:1-5

97. Padhi SK, Singh RK (2011) Non-edible oils as the potential source for the production of biodiesel in India: a review. J Chem Pharm Res 3:39-49

98. Prasad RBN (2008) Value added byproducts from oilseed cakes. https://www.compete-bioafrica.net/events/events2/seminar_ india/ppt/4-1-Prasad.pdf (Accessed on 26 Nov 2021)

99. Kiran SC, Nagarajaiah C, Prasanna KT, Rajeshkumar K (2019) Studies on bioavailability of nutrients in decomposed crushed seeds, oil cakes and deoiled cakes of neem (Azadirachta indica L.). J Pharmacogn Phytochem 8:163-165

100. Osman M, Wani SP, Balloli SS, Sreedevi TK, Rao CS, D'Silva E (2009) Pongamia seed cake as a valuable source of plant nutrients for sustainable agriculture. Indian J Fert 5:25-26

101. Palaniveloo K, Amran MA, Norhashim NA et al (2020) Food waste composting and microbial community structure profiling. Processes 8:723. https://doi.org/10.3390/pr8060723

102. Kour D, Rana KL, Yadav AN et al (2020) Microbial biofertilizers: bioresources and eco-friendly technologies for agricultural 
and environmental sustainability. Biocatal Agric Biotechnol 23:101487. https://doi.org/10.1016/j.bcab.2019.101487

103 Singh R, Kumar A, Tomer A (2015) De-oiled cakes of neem, Jatropha, mahua and Karanja: a new substrate for mass multiplication of T. harzianum. J Plant Pathol Microbiol 06:288. https:// doi.org/10.4172/2157-7471.1000288

104. Tomer A, Singh R, Maurya M (2014) Determination of suitability of deoiled cakes of neem and Jatropha for mass multiplication of Pseudomonas fluorescens. J Plant Pathol Microbiol 5:237. https://doi.org/10.4172/2157-7471.1000237

105. Gupta A, Chaudhary R, Sharma S (2012) Potential applications of mahua (Madhuca indica) Biomass. Waste Biomass Valor 3:175-189. https://doi.org/10.1007/s12649-012-9107-9

106. Das M, Uppal HS, Singh R et al (2011) Co-composting of physic nut (Jatropha curcas) deoiled cake with rice straw and different animal dung. Bioresour Technol 102:6541-6546. https://doi.org/ 10.1016/j.biortech.2011.03.058

107. Lima RLS, Severino LS, Sampaio LR et al (2011) Blends of castor meal and castor husks for optimized use as organic fertilizer. Ind Crops Prod 33:364-368. https://doi.org/10.1016/j.indcrop. 2010.11.008

108. Sharma A, Gupta A, Dalela M et al (2020) Linking organic metabolites as produced by Purpureocillium Lilacinum 6029 cultured on Karanja deoiled cake medium for the sustainable management of root-knot nematodes. Sustainability 12:8276. https://doi.org/10.3390/su12198276

109. Arora K, Sharma S, Krishna SBN et al (2017) Non-edible oil cakes as a novel substrate for DPA production and augmenting biocontrol activity of Paecilomyces variotii. Front Microbiol 8:753. https://doi.org/10.3389/fmicb.2017.00753

110. Sharma S, Verma M, Sharma A (2013) Utilization of non edible oil seed cakes as substrate for growth of Paecilomyces lilacinus and as biopesticide against termites. Waste Biomass Valor 4:325-330. https://doi.org/10.1007/s12649-012-9134-6

111. Tomer A, Singh R, Singh P (2016) Suitability of de-oiled cakes of Neem, Jatropha, Mahua and Karanja along with cereals and millets substrates for mass multiplication of Trichoderma harzianum. Acad Agric J 1:23-27

112. Tomer A, Singh R, Maurya M (2015) Determination of compatibility of Pseudomonas fluorescens and Trichoderma harzianum grown on deoiled cakes of Neem and Jatropha for mass multiplication of P. fluorescens and T. harzianum In-Vitro. Afr J Agric Res 10:67-75. https://doi.org/10.5897/AJAR2014.8874

113. Rizvi R, Singh G, Safiuddin et al (2015) Sustainable management of root-knot disease of tomato by neem cake and Glomus fasciculatum. Cogent Food Agric 1:1008859. https://doi.org/10. 1080/23311932.2015.1008859

114. Rizvi R, Mahmood I, Tiyagi SA, Khan Z (2012) Conjoint effect of oil-seed cakes and Pseudomonas fluorescens on the growth of chickpea in relation to the management of plant-parasitic nematodes. Br Arch Biol Technol 55:801-808. https://doi.org/ 10.1590/S1516-89132012000600001

115. Tiyagi SA, Mahmood I, Khan Z, Ahmad H (2011) Biological control of soil-pathogenic nematodes infecting mungbean using Pseudomonas fluorescens. Arch Phytopathol Plant Prot 44:17701778. https://doi.org/10.1080/03235401003633840

116. Sharma A, Sharma S, Yadav S, Naik SN (2014) Role of Karanja deoiled cake based medium in production of protease and fatty acids by Paecilomyces lilacinus 6029. J Biosci Bioeng 118:270 271. https://doi.org/10.1016/j.jbiosc. 2014.02.020

117. Hamid S, Ahmad I, Akhtar MJ et al (2021) Bacillus subtilis Y16 and biogas slurry enhanced potassium to sodium ratio and physiology of sunflower (Helianthus annuus L.) to mitigate salt stress. Environ Sci Pollut Res 28:38637-38647. https://doi.org/10.1007/ s11356-021-13419-2
118. Ahmad M, Zahir ZA, Jamil M, Nazli F, Latif M, Akhtar MF (2014) Integrated use of plant growth promoting rhizobacteria, biogas slurry and chemical nitrogen for sustainable production of maize under salt-affected conditions. Pak J Bot 46:375-382

119 Gao C, El-Sawah AM, Ali DFI et al (2020) The integration of bio and organic fertilizers improve plant growth, grain yield, quality and metabolism of hybrid maize (Zea mays L). Agronomy 10:319. https://doi.org/10.3390/agronomy10030319

120. Yadav A, Gupta R, Garg V (2013) Organic manure production from cow dung and biogas plant slurry by vermicomposting under field conditions. Int J Recycl Org Waste Agric 2:21. https:// doi.org/10.1186/2251-7715-2-21

121. Hao X, Ma X, Zeng B et al (2021) Efficiency and mechanism of a vermicompost additive in enhancing composting of swine manure. Environ Sci Pollut Res. https://doi.org/10.1007/ s11356-021-14498-x

122. Chaka BA, Osano AM, Maghanga JK, Magu MM (2020) Optimization of bioslurry-available plant nutrients using T. brownii and Acanthaceae spp. biocatalysts. Adv Agric 2020:1-12. https:// doi.org/10.1155/2020/4526485

123. Zhang M, Wang Z, Zhang X et al (2020) Biogas and quality fertilizer production from dry anaerobic digestion of rice straw with nitrogen addition. Bioresour Technol Rep 11:100509. https://doi. org/10.1016/j.biteb.2020.100509

124. Jilani TA, Waseem K, Sherani J, Kamaran S, Jilani MS, Ahmad T, Manan A, Ullah S, Nazim K, Saleem H (2021) Rationalization of bio-slurry and chemical fertilizer combinations for growth and pod yield of pea (Pisum sativum L.) under two growing seasons. Int J Emerg Technol 12:139-147

125. Jamison J, Khanal SK, Nguyen NH, Deenik JL (2021) Assessing the effects of digestates and combinations of digestates and fertilizer on yield and nutrient use of Brassica juncea (Kai Choy). Agronomy 11:509. https://doi.org/10.3390/agronomy11030509

126 Do TCV, Scherer HW (2012) Compost and biogas residues as basic materials for potting substrates. Plant Soil Environ 58:459464. https://doi.org/10.17221/445/2012-PSE

127. Fraire García DA, López Ortiz CE, Hernández De Lira IO, Balagurusamy N (2018) Evaluation of biodigester slurry application as an organic fertilizer on different crops of Comarca lagunera and its effect on soil enzyme activities. In: Rios-Vazquez NJ, Ulloa-Mercado RG, Sánchez-Duarte RG, Correa-Murrieta MA, Gortarez-Moroyoqui P (eds) Book of Abstracts Environmental Biotechnology and Engineering-2018. ITSON, Cd Obregón México

128. Ronga D, Setti L, Salvarani C et al (2019) Effects of solid and liquid digestate for hydroponic baby leaf lettuce (Lactuca sativa L.) cultivation. Sci Hortic 244:172-181. https://doi.org/10.1016/j. scienta.2018.09.037

129. Malav LC, Khan SA, Gupta N (2015) Impacts of biogas slurry application on soil environment, yield and nutritional quality of baby corn. Vegetos- An Int J Plant Res 28:194. https://doi.org/ 10.5958/2229-4473.2015.00055.5

130. Somasundaram E, Amanullah MM, Vaiyapuri K, Thirukkumaran K, Sathyamoorthi K (2007) Influence of organic sources of nutrients on the yield and economics of crops under maize based cropping system. Journal of Appl Sci Res 3:1774-1777

131. Raliya R, Tarafdar JC (2013) ZnO nanoparticle biosynthesis and its effect on phosphorous-mobilizing enzyme secretion and gum contents in Clusterbean (Cyamopsis tetragonoloba L.). Agric Res 2:48-57. https://doi.org/10.1007/s40003-012-0049-Z

132. Wang K, Yun S, Xing T et al (2021) Binary and ternary trace elements to enhance anaerobic digestion of cattle manure: focusing on kinetic models for biogas production and digestate utilization. Bioresour Technol 323:124571. https://doi.org/10.1016/j.biort ech. 2020.124571 
133. Wang P, Wang X, Chen X, Ren L (2021) Effects of bentonite on antibiotic resistance genes in biogas slurry and residue from thermophilic and mesophilic anaerobic digestion of food waste. Bioresour Technol 336:125322. https://doi.org/10.1016/j.biort ech.2021.125322

134. Xu H, Yun S, Wang $C$ et al (2020) Improving performance and phosphorus content of anaerobic co-digestion of dairy manure with aloe peel waste using vermiculite. Bioresour Technol 301:122753. https://doi.org/10.1016/j.biortech.2020.122753

135. Wu X, Tian Z, Lv Z et al (2020) Effects of copper salts on performance, antibiotic resistance genes, and microbial community during thermophilic anaerobic digestion of swine manure. Bioresour Technol 300:122728. https://doi.org/10.1016/j.biort ech.2019.122728

136. Farghali M, Andriamanohiarisoamanana FJ, Ahmed MM et al (2020) Prospects for biogas production and H2S control from the anaerobic digestion of cattle manure: the influence of microscale waste iron powder and iron oxide nanoparticles. Waste Manag 101:141-149. https://doi.org/10.1016/j.wasman.2019.10.003

137. Xu L, Peng S, Dong D et al (2019) Performance and microbial community analysis of dry anaerobic co-digestion of rice straw and cow manure with added limonite. Biomass Bioenergy 126:41-46. https://doi.org/10.1016/j.biombioe.2019.04.026

138. Lu T, Zhang J, Wei Y, Shen P (2019) Effects of ferric oxide on the microbial community and functioning during anaerobic digestion of swine manure. Bioresour Technol 287:121393. https://doi.org/10.1016/j.biortech.2019.121393

139. Bi S, Westerholm M, Qiao W et al (2019) Enhanced methanogenic performance and metabolic pathway of high solid anaerobic digestion of chicken manure by $\mathrm{Fe}^{2+}$ and $\mathrm{Ni}^{2+}$ supplementation. Waste Manag 94:10-17. https://doi.org/10.1016/j.wasman. 2019.05.036

140. Wijesinghe DTN, Dassanayake KB, Sommer SG et al (2019) Biogas improvement by adding Australian zeolite during the anaerobic digestion of $\mathrm{C}: \mathrm{N}$ ratio adjusted swine manure. Waste Biomass Valor 10:1883-1887. https://doi.org/10.1007/ s12649-018-0210-4

141. Yang Y, Yang F, Huang W et al (2018) Enhanced anaerobic digestion of ammonia-rich swine manure by zero-valent iron: with special focus on the enhancement effect on hydrogenotrophic methanogenesis activity. Bioresour Technol 270:172179. https://doi.org/10.1016/j.biortech.2018.09.008

142. Lu X, Wang H, Ma F et al (2017) Enhanced anaerobic digestion of cow manure and rice straw by the supplementation of an iron oxide-zeolite system. Energy Fuels 31:599-606. https://doi.org/ 10.1021/acs.energyfuels.6b02244

143. Wang Y, Ren G, Zhang T et al (2017) Effect of magnetite powder on anaerobic co-digestion of pig manure and wheat straw. Waste Manag 66:46-52. https://doi.org/10.1016/j.wasman.2017.04.031

144. Montalvo S, Cahn I, Borja R et al (2017) Use of solid residue from thermal power plant (fly ash) for enhancing sewage sludge anaerobic digestion: Influence of fly ash particle size. Bioresour Technol 244:416-422. https://doi.org/10.1016/j.biortech.2017. 07.159

145. Wang X, Zhang L, Xi B et al (2015) Biogas production improvement and $\mathrm{C} / \mathrm{N}$ control by natural Clinoptilolite addition into anaerobic co-digestion of Phragmites australis, feces and kitchen waste. Bioresour Technol 180:192-199. https://doi.org/10.1016/j. biortech.2014.12.023

146. Cruz Viggi C, Rossetti S, Fazi S et al (2014) Magnetite particles triggering a faster and more robust syntrophic pathway of methanogenic propionate degradation. Environ Sci Technol 48:7536-7543. https://doi.org/10.1021/es5016789

147. Luna-delRisco M, Orupõld K, Dubourguier H-C (2011) Particlesize effect of $\mathrm{CuO}$ and $\mathrm{ZnO}$ on biogas and methane production during anaerobic digestion. J Hazard Mater 189:603-608. https:// doi.org/10.1016/j.jhazmat.2011.02.085

148. Fermoso FG, Bartacek J, Jansen S, Lens PNL (2009) Metal supplementation to UASB bioreactors: from cell-metal interactions to full-scale application. Sci Total Environ 407:3652-3667. https://doi.org/10.1016/j.scitotenv.2008.10.043

149. Abdelsalam EM, El-Hussein A, Samer M (2021) Photobiostimulation of anaerobic digestion by laser irradiation and photocatalytic effects of trace metals and nanomaterials on biogas production. Int J Energy Res 45:141-150. https://doi.org/10.1002/er. 5817

150. Samer M, Hijazi O, Abdelsalam EM et al (2021) Life cycle assessment of using laser treatment and nanomaterials to produce biogas through anaerobic digestion of slurry. Environ Dev Sustain. https://doi.org/10.1007/s10668-021-01264-9

151. Abdelwahab TAM, Mohanty MK, Sahoo PK, Behera D (2021a) Impact of nickel nanoparticles on biogas production from cattle manure. Biomass Conv Bioref https://doi.org/10.1007/ s13399-021-01460-7

152. Sliem MA, El-Ansary S, Soliman W, Badr Y (2021) Enhancing biogas production of cow dung during anaerobic digestion using nanoferrites. Biomass Conv Bioref. https://doi.org/10. 1007/s13399-021-01683-8

153. Abdelwahab TAM, Mohanty MK, Sahoo PK, Behera D (2021b) Metal nanoparticle mixtures to improve the biogas yield of cattle manure. Biomass Conv Bioref https://doi.org/10.1007/ s13399-021-01286-3

154. Abdelwahab TAM, Mohanty MK, Sahoo PK, Behera D (2020a) Impact of iron nanoparticles on biogas production and effluent chemical composition from anaerobic digestion of cattle manure. Biomass Conv Bioref https://doi.org/10.1007/ s13399-020-00985-7

155. Amo-Duodu G, Rathilal S, Chollom MN, Kweinor Tetteh E (2021) Application of metallic nanoparticles for biogas enhancement using the biomethane potential test. Sci Afr 12:e00728. https://doi.org/10.1016/j.sciaf.2021.e00728

156. Grosser A, Grobelak A, Rorat A et al (2021) Effects of silver nanoparticles on performance of anaerobic digestion of sewage sludge and associated microbial communities. Renew Energy 171:1014-1025. https://doi.org/10.1016/j.renene.2021.02.127

157. Barrena R, Vargas-García M del C, Capell G et al (2021) Sustained effect of zero-valent iron nanoparticles under semi-continuous anaerobic digestion of sewage sludge: evolution of nanoparticles and microbial community dynamics. Sci Total Environ 777:145969. https://doi.org/10.1016/j.scitotenv.2021.145969

158. Hassaan MA, Pantaleo A, Tedone L et al (2021) Enhancement of biogas production via green $\mathrm{ZnO}$ nanoparticles: experimental results of selected herbaceous crops. Chem Eng Commun 208:242-255. https://doi.org/10.1080/00986445.2019.1705797

159. Kaushal R, Baitha R (2021) Biogas and methane yield enhancement using graphene oxide nanoparticles and $\mathrm{Ca}(\mathrm{OH})_{2}$ pre-treatment in anaerobic digestion. Int J Ambient Energy 42:618-625. https://doi.org/10.1080/01430750.2018.1562975

160. Salama AM, Helmy EA, Abd El-ghany TM, Ganash M (2021) Nickel oxide nanoparticles application for enhancing biogas production using certain wastewater bacteria and aquatic macrophytes biomass. Waste Biomass Valor 12:2059-2070. https:// doi.org/10.1007/s12649-020-01144-9

161. Rana MS, Bhushan S, Prajapati SK (2020) New insights on improved growth and biogas production potential of Chlorella pyrenoidosa through intermittent iron oxide nanoparticle supplementation. Sci Rep 10:14119. https://doi.org/10.1038/ s41598-020-71141-4

162. Hassaan MA, Pantaleo A, Santoro F et al (2020) Techno-economic analysis of $\mathrm{ZnO}$ nanoparticles pretreatments for biogas 
production from barley straw. Energies 13:5001. https://doi.org/ 10.3390/en13195001

163. Shi Y, Huang K, Feng R et al (2020) Combined MgO nanoparticle and microwave pre-treatment on biogas increase from Enteromorpha during anaerobic digestion. IOP Conf Ser: Earth Environ Sci 450:012025. https://doi.org/10.1088/1755-1315/ 450/1/012025

164. El-Borady OM, Fawzy M, Abedin RMA, Salama AM (2020) Enhancement of biogas production from plant biomass using iron nanoparticles. In: Ezziyyani M (ed) Advanced Intelligent Systems for Sustainable Development (AI2SD'2019). Springer International Publishing, Cham, Vol. 624, pp 110-126 https://doi. org/10.1007/978-3-030-36475-5_11

165. Abdelsalam E, Samer M, Attia YA et al (2017) Effects of Co and Ni nanoparticles on biogas and methane production from anaerobic digestion of slurry. Energy Convers Manag 141:108-119. https://doi.org/10.1016/j.enconman.2016.05.051

166. Abdelsalam E, Samer M, Attia YA et al (2017) Influence of zero valent iron nanoparticles and magnetic iron oxide nanoparticles on biogas and methane production from anaerobic digestion of manure. Energy 120:842-853. https://doi.org/10.1016/j.energy. 2016.11.137

167. Juntupally S, Begum S, Allu SK et al (2017) Relative evaluation of micronutrients (MN) and its respective nanoparticles (NPs) as additives for the enhanced methane generation. Bioresour Technol 238:290-295. https://doi.org/10.1016/j.biortech.2017. 04.049

168. Hijazi O, Abdelsalam E, Samer M et al (2020) Environmental impacts concerning the addition of trace metals in the process of biogas production from anaerobic digestion of slurry. J Clean Prod 243:118593. https://doi.org/10.1016/j.jclepro.2019.118593

169. Liu X, Qi L, Chatzisymeon E et al (2021) Inorganic additives to increase methane generation during anaerobic digestion of livestock manure: a review. Environ Chem Lett. https://doi.org/ 10.1007/s10311-021-01282-Z

170. Yang Y, Wang J, Zhou Y (2019) Enhanced anaerobic digestion of swine manure by the addition of zero-valent iron. Energy Fuels 33:12441-12449. https://doi.org/10.1021/acs.energyfuels.9b024 98

171. Ye W, Lu J, Ye J, Zhou Y (2021) The effects and mechanisms of zero-valent iron on anaerobic digestion of solid waste: a minireview. J Clean Prod 278:123567. https://doi.org/10.1016/j.jclep ro.2020.123567

172. Abdelsalam EM, Samer M (2019) Biostimulation of anaerobic digestion using nanomaterials for increasing biogas production. Rev Environ Sci Biotechnol 18:525-541. https://doi.org/10.1007/ s11157-019-09505-0

173. Juntupally S, Arelli V, Begum S, Anupoju GR (2020) Improved biomethanation of horse manure through acid-thermal pretreatment and supplementation of iron nanoparticles under mesophilic and thermophilic conditions. Biomass Conv Bioref. https:// doi.org/10.1007/s13399-020-01085-2

174. Raliya R, Saharan V, Dimkpa C, Biswas P (2018) Nanofertilizer for precision and sustainable agriculture: current state and future perspectives. J Agric Food Chem 66:6487-6503. https://doi.org/ 10.1021/acs.jafc.7b02178

175. Yang X, Nie J, Wei Y et al (2020) Simultaneous enhancement on lignin degradation and methane production from anaerobic co-digestion of waste activated sludge and alkaline lignin supplemented with $\mathrm{N}_{2}$-nanobubble water. Bioresour Technol Rep 11:100470. https://doi.org/10.1016/j.biteb.2020.100470

176. Kumar SS, Ghosh P, Kataria N et al (2021) The role of conductive nanoparticles in anaerobic digestion: mechanism, current status and future perspectives. Chemosphere 280:130601. https:// doi.org/10.1016/j.chemosphere.2021.130601
177. Zhang J, Wang Z, Lu T et al (2019) Response and mechanisms of the performance and fate of antibiotic resistance genes to nanomagnetite during anaerobic digestion of swine manure. J Hazard Mater 366:192-201. https://doi.org/10.1016/j.jhazmat.2018.11. 106

178. Farghali M, Andriamanohiarisoamanana FJ, Ahmed MM et al (2019) Impacts of iron oxide and titanium dioxide nanoparticles on biogas production: hydrogen sulfide mitigation, process stability, and prospective challenges. J Environ Manag 240:160-167. https://doi.org/10.1016/j.jenvman.2019.03.089

179. Wang Z, Yun S, Shi J et al (2020) Critical evidence for direct interspecies electron transfer with tungsten-based accelerants: an experimental and theoretical investigation. Bioresour Technol 311:123519. https://doi.org/10.1016/j.biortech.2020.123519

180. Van Steendam C, Smets I, Skerlos S, Raskin L (2019) Improving anaerobic digestion via direct interspecies electron transfer requires development of suitable characterization methods. Curr Opin Biotechnol 57:183-190. https://doi.org/10.1016/j.copbio. 2019.03.018

181. Kato S, Hashimoto K, Watanabe K (2012) Methanogenesis facilitated by electric syntrophy via (semi)conductive ironoxide minerals: methanogenesis via (semi)conductive minerals. Environ Microbiol 14:1646-1654. https://doi.org/10. 1111/j.1462-2920.2011.02611.x

182. Hassaneen FY, Abdallah MS, Ahmed N et al (2020) Innovative nanocomposite formulations for enhancing biogas and biofertilizers production from anaerobic digestion of organic waste. Bioresour Technol 309:123350. https://doi.org/10.1016/j.biort ech.2020.123350

183. Eduok S, Ferguson R, Jefferson B et al (2017) Aged-engineered nanoparticles effect on sludge anaerobic digestion performance and associated microbial communities. Sci Total Environ 609:232-241. https://doi.org/10.1016/j.scitotenv.2017.07.178

184. Welander PV, Metcalf WW (2005) Loss of the mtr operon in Methanosarcina blocks growth on methanol, but not methanogenesis, and reveals an unknown methanogenic pathway. Proc Natl Acad Sci 102:10664-10669. https://doi.org/10.1073/pnas. 0502623102

185. He Q, Gao S, Zhang S et al (2017) Chronic responses of aerobic granules to zinc oxide nanoparticles in a sequencing batch reactor performing simultaneous nitrification, denitrification and phosphorus removal. Bioresour Technol 238:95-101. https://doi.org/10.1016/j.biortech.2017.04.010

186. Zhang Y, Xu R, Xiang Y et al (2021) Addition of nanoparticles increases the abundance of mobile genetic elements and changes microbial community in the sludge anaerobic digestion system. J Hazard Mater 405:124206. https://doi.org/10. 1016/j.jhazmat.2020.124206

187. Tong T, Fang K, Thomas SA et al (2014) Chemical interactions between nano- $\mathrm{ZnO}$ and nano- $\mathrm{TiO}_{2}$ in a natural aqueous medium. Environ Sci Technol 48:7924-7932. https://doi.org/ 10.1021/es501168p

188. Tong T, Wilke CM, Wu J et al (2015) Combined toxicity of nano- $\mathrm{ZnO}$ and nano- $\mathrm{TiO}_{2}$ : from single- to multinanomaterial systems. Environ Sci Technol 49:8113-8123. https://doi.org/ $10.1021 /$ acs.est.5b02148

189. Ye J, Gao H, Wu J et al (2020) Responses of nitrogen transformation processes and $\mathrm{N}_{2} \mathrm{O}$ emissions in biological nitrogen removal system to short-term $\mathrm{ZnO}$ nanoparticle stress. Sci Total Environ 705:135916. https://doi.org/10.1016/j.scitotenv. 2019.135916

190. Zhang L, Zhang Z, He X et al (2019) Diminished inhibitory impact of $\mathrm{ZnO}$ nanoparticles on anaerobic fermentation by the presence of $\mathrm{TiO}_{2}$ nanoparticles: phenomenon and mechanism. Sci Total Environ 647:313-322. https://doi.org/10.1016/j.scito tenv.2018.07.468 
191. Liu G, Wang D, Wang J, Mendoza C (2011) Effect of ZnO particles on activated sludge: role of particle dissolution. Sci Total Environ 409:2852-2857. https://doi.org/10.1016/j.scitotenv. 2011.03.022

192. Hijazi O, Abdelsalam E, Samer M et al (2020) Life cycle assessment of the use of nanomaterials in biogas production from anaerobic digestion of manure. Renew Energy 148:417-424. https://doi.org/10.1016/j.renene.2019.10.048

193. Nguyen D, Visvanathan C, Jacob P, Jegatheesan V (2015) Effects of nano cerium (IV) oxide and zinc oxide particles on biogas production. Int Biodeterior Biodegrad 102:165-171. https://doi. org/10.1016/j.ibiod.2015.02.014

194. García A, Delgado L, Torà JA et al (2012) Effect of cerium dioxide, titanium dioxide, silver, and gold nanoparticles on the activity of microbial communities intended in wastewater treatment. J Hazard Mater 199-200:64-72. https://doi.org/10.1016/j.jhazm at.2011.10.057

195. Yang Y, Guo J, Hu Z (2013) Impact of nano zero valent iron (NZVI) on methanogenic activity and population dynamics in anaerobic digestion. Water Res 47:6790-6800. https://doi.org/ 10.1016/j.watres.2013.09.012

196. Ma J, Gu J, Wang X et al (2019) Effects of nano-zerovalent iron on antibiotic resistance genes during the anaerobic digestion of cattle manure. Bioresour Technol 289:121688. https://doi.org/ 10.1016/j.biortech.2019.121688

197. Zheng X, Liu Y, Huang J et al (2020) The influence of variables on the bioavailability of heavy metals during the anaerobic digestion of swine manure. Ecotoxicol Environ Saf 195:110457. https://doi.org/10.1016/j.ecoenv.2020.110457

198. Hassanein A, Keller E, Lansing S (2021) Effect of metal nanoparticles in anaerobic digestion production and plant uptake from effluent fertilizer. Bioresour Technol 321:124455. https://doi.org/ 10.1016/j.biortech.2020.124455

199. Hui X, Kui H (2021) Effects of $\mathrm{TiO}_{2}$ and $\mathrm{ZnO}$ nanoparticles on vermicomposting of dewatered sludge: studies based on the humification and microbial profiles of vermicompost. Environ Sci Pollut Res 28:38718-38729. https://doi.org/10.1007/ s11356-021-13226-9

200. Mu H, Chen Y, Xiao N (2011) Effects of metal oxide nanoparticles $(\mathrm{TiO} 2, \mathrm{Al} 2 \mathrm{O} 3, \mathrm{SiO} 2$ and $\mathrm{ZnO})$ on waste activated sludge anaerobic digestion. Bioresour Technol 102:10305-10311. https://doi.org/10.1016/j.biortech.2011.08.100

201. Menkveld HWH, Broeders E (2018) Recovery of ammonia from digestate as fertilizer. Water Pract Technol 13:382-387. https:// doi.org/10.2166/wpt.2018.049

202. Battista F, Masala C, Zamboni A et al (2021) Valorisation of agricultural digestate for the ammonium sulfate recovery and soil improvers production. Waste Biomass Valor. https://doi.org/10. 1007/s12649-021-01486-y

203. Ehmann A, Bach I-M, Bilbao J et al (2019) Phosphates recycled from semi-liquid manure and digestate are suitable alternative fertilizers for ornamentals. Sci Hortic 243:440-450. https://doi. org/10.1016/j.scienta.2018.08.052

204. Gienau T, Brüß U, Kraume M, Rosenberger S (2018) Nutrient recovery from biogas digestate by optimised membrane treatment. Waste Biomass Valor 9:2337-2347. https://doi.org/10. 1007/s12649-018-0231-z

205. He QY, Wang WC, Liu L, Yu G, Yan SP (2016) Ammonia nitrogen separation performance and kinetics from biogas slurry using vacuum distillation method. Trans Chin Soc Agric Eng (Transactions of the CSAE) 32:191-197 https://doi.org/10.11975/j.issn. 1002-6819.2016.17.026

206. $\mathrm{He} \mathrm{Q}, \mathrm{Yu} \mathrm{G}$, Wang W et al (2017) Once-through $\mathrm{CO}_{2}$ absorption for simultaneous biogas upgrading and fertilizer production. Fuel Process Technol 166:50-58. https://doi.org/10.1016/j.fuproc. 2017.05.027
207. $\mathrm{He} \mathrm{Q}, \mathrm{Yu} \mathrm{G}$, Yan S et al (2018) Renewable $\mathrm{CO}_{2}$ absorbent for carbon capture and biogas upgrading by membrane contactor. Sep Purif Technol 194:207-215. https://doi.org/10.1016/j.seppur. 2017.11.043

208. Chen B, Shao Y, Shi M et al (2021) Anaerobic digestion of chicken manure coupled with ammonia recovery by vacuumassisted gas-permeable membrane process. Biochem Eng J 175:108135. https://doi.org/10.1016/j.bej.2021.108135

209. He Q, Xi J, Shi M et al (2020) Developing a vacuum-assisted gas-permeable membrane process for rapid ammonia recovery and $\mathrm{CO}_{2}$ capture from biogas slurry. ACS Sustain Chem Eng 8:154-162. https://doi.org/10.1021/acssuschemeng.9b04873

210. García-González MC, Vanotti MB, Szogi AA (2016) Recovery of ammonia from anaerobically digested manure using gas-permeable membranes. Sci Agric (Piracicaba, Braz) 73:434-438 https://doi.org/10.1590/0103-9016-2015-0159

211. Campos JL, Crutchik D, Franchi Ó et al (2019) Nitrogen and phosphorus recovery from anaerobically pretreated agro-food wastes: a review. Front Sustain Food Syst 2:91. https://doi.org/ 10.3389/fsufs. 2018.00091

212. Cerrillo M, Burgos L, Bonmatí A (2021) Biogas upgrading and ammonia recovery from livestock manure digestates in a combined electromethanogenic biocathode-hydrophobic membrane system. Energies 14:503. https://doi.org/10.3390/ en 14020503

213. Li B, Jing F, Hu Z et al (2021) Simultaneous recovery of nitrogen and phosphorus from biogas slurry by Fe-modified biochar. J Saudi Chem Soc 25:101213. https://doi.org/10.1016/j.jscs.2021. 101213

214. Rosales E, Meijide J, Pazos M, Sanromán MA (2017) Challenges and recent advances in biochar as low-cost biosorbent: from batch assays to continuous-flow systems. Bioresour Technol 246:176-192. https://doi.org/10.1016/j.biortech.2017.06.084

215. Kubar AA, Huang Q, Sajjad M et al (2021) The recovery of phosphate and ammonium from biogas slurry as value-added fertilizer by biochar and struvite co-precipitation. Sustainability 13:3827. https://doi.org/10.3390/su13073827

216. Jin H, Hanif MU, Capareda S et al (2016) Copper(II) removal potential from aqueous solution by pyrolysis biochar derived from anaerobically digested algae-dairy-manure and effect of KOH activation. J Environ Chem Eng 4:365-372. https://doi. org/10.1016/j.jece.2015.11.022

217. Kizito S, Wu S, Wandera SM et al (2016) Evaluation of ammonium adsorption in biochar-fixed beds for treatment of anaerobically digested swine slurry: experimental optimization and modeling. Sci Total Environ 563-564:1095-1104. https://doi. org/10.1016/j.scitotenv.2016.05.149

218. Kizito S, Wu S, Kipkemoi Kirui W et al (2015) Evaluation of slow pyrolyzed wood and rice husks biochar for adsorption of ammonium nitrogen from piggery manure anaerobic digestate slurry. Sci Total Environ 505:102-112. https://doi.org/10.1016/j. scitotenv.2014.09.096

219. Luo L, Lin X, Zeng F et al (2019) Performance of a novel photobioreactor for nutrient removal from piggery biogas slurry: operation parameters, microbial diversity and nutrient recovery potential. Bioresour Technol 272:421-432. https://doi.org/10. 1016/j.biortech.2018.10.057

220. Sobhi M, Guo J, Cui X et al (2019) A promising strategy for nutrient recovery using heterotrophic indigenous microflora from liquid biogas digestate. Sci Total Environ 690:492-501. https:// doi.org/10.1016/j.scitotenv.2019.06.487

221. Parr JF, Hornick SB, Kaufman DD (1994) Use of microbial inoculants and organic fertilizers in agricultural production. ASPAC Food \& Fertilizer Technology Center. https://www.fftc.org.tw/ htmlarea_file/library/20110722114739/eb394.pdf (Accessed 23 January 2021) 
222. https://www.marketsandmarkets.com. Biofertilizers market by form (liquid, carrier-based), mode of application (soil treatment, seed treatment), type (nitrogen-fixing, phosphate solubilizing \& mobilizing, potash solubilizing \& mobilizing), crop type, and region-global forecast to 2026. Report Code: AGI 2569. Published May 2021. (Accessed 02 August 2021)

223. https://www.grandviewresearch.com/industry-analysis/biofertili zers-industry. Biofertilizers market size, share \& trends analysis report by product (nitrogen fixing, phosphate solubilizing), by application (seed treatment, soil treatment), by crop type, by region, and segment forecasts, 2020-2027. Report ID: 978-168038-038-5. Published June 2020. (Accessed 02 August 2021)

224. Rachmah MA, Darwanto DH, Mulyo JH (2020) Farmers' willingness to pay for bio-slurry fertilizer in Central Java. AE 31:112. https://doi.org/10.22146/ae.56790

225. Ghafoori E, Flynn P, Feddes J (2007) Pipeline vs. truck transport of beef cattle manure. Biomass Bioenergy 31:168-175. https:// doi.org/10.1016/j.biombioe.2006.07.007

226. Zheng L, Cheng S, Han Y et al (2020) Bio-natural gas industry in China: current status and development. Renew Sustain Energy Rev 128:109925. https://doi.org/10.1016/j.rser.2020.109925

227. Rana A, Kabi SR, Verma S et al (2015) Prospecting plant growth promoting bacteria and cyanobacteria as options for enrichment of macro- and micronutrients in grains in rice-wheat cropping sequence. Cogent Food Agric 1:1037379. https://doi.org/10. 1080/23311932.2015.1037379

228. Kiran SC (2017) Studies on bioavailability of nutrients in decomposed crushed seeds, oil cakes and deoiled cakes of neem (Azadirachta indica). Student project programme-Biofuel $40^{\text {th }}$ Series 2016-2017 (Final Project Report). http://www.kscst.iisc. ernet.in/spp/41_series/40S_bestprojreports/40S_B_MSc_014. pdf (Accessed on 26 July 2021)
229. Raheman H, Mondal S (2012) Biogas production potential of jatropha seed cake. Biomass Bioenergy 37:25-30. https://doi. org/10.1016/j.biombioe.2011.12.042

230. https://fert.nic.in/p-and-k-fertilizers (Accessed 25 July 2021)

231. Abdelwahab TAM, Mohanty MK, Sahoo PK, Behera D (2020b) Application of nanoparticles for biogas production: current status and perspectives. Energy Sources Part A: Recover Utilization Environ Effects 1-13https://doi.org/10.1080/15567036.2020. 1767730

232. Biswal AK, Misra PK (2020) Biosynthesis and characterization of silver nanoparticles for prospective application in food packaging and biomedical fields. Mater Chem Phys 250:123014. https:// doi.org/10.1016/j.matchemphys.2020.123014

233. Nayak S, Sajankila SP, Rao C Vaman, et al (2019) Biogenic synthesis of silver nanoparticles using Jatropha curcas seed cake extract and characterization: evaluation of its antibacterial activity. Energy Sources, Part A: Recover Utilization Environ Effects 1-9https://doi.org/10.1080/15567036.2019.1632394

234. Zhao L, Ji Y, Sun P et al (2019) Effects of individual and combined zinc oxide nanoparticle, norfloxacin, and sulfamethazine contamination on sludge anaerobic digestion. Bioresour Technol 273:454-461. https://doi.org/10.1016/j.biortech.2018.11.049

Publisher's note Springer Nature remains neutral with regard to jurisdictional claims in published maps and institutional affiliations. 